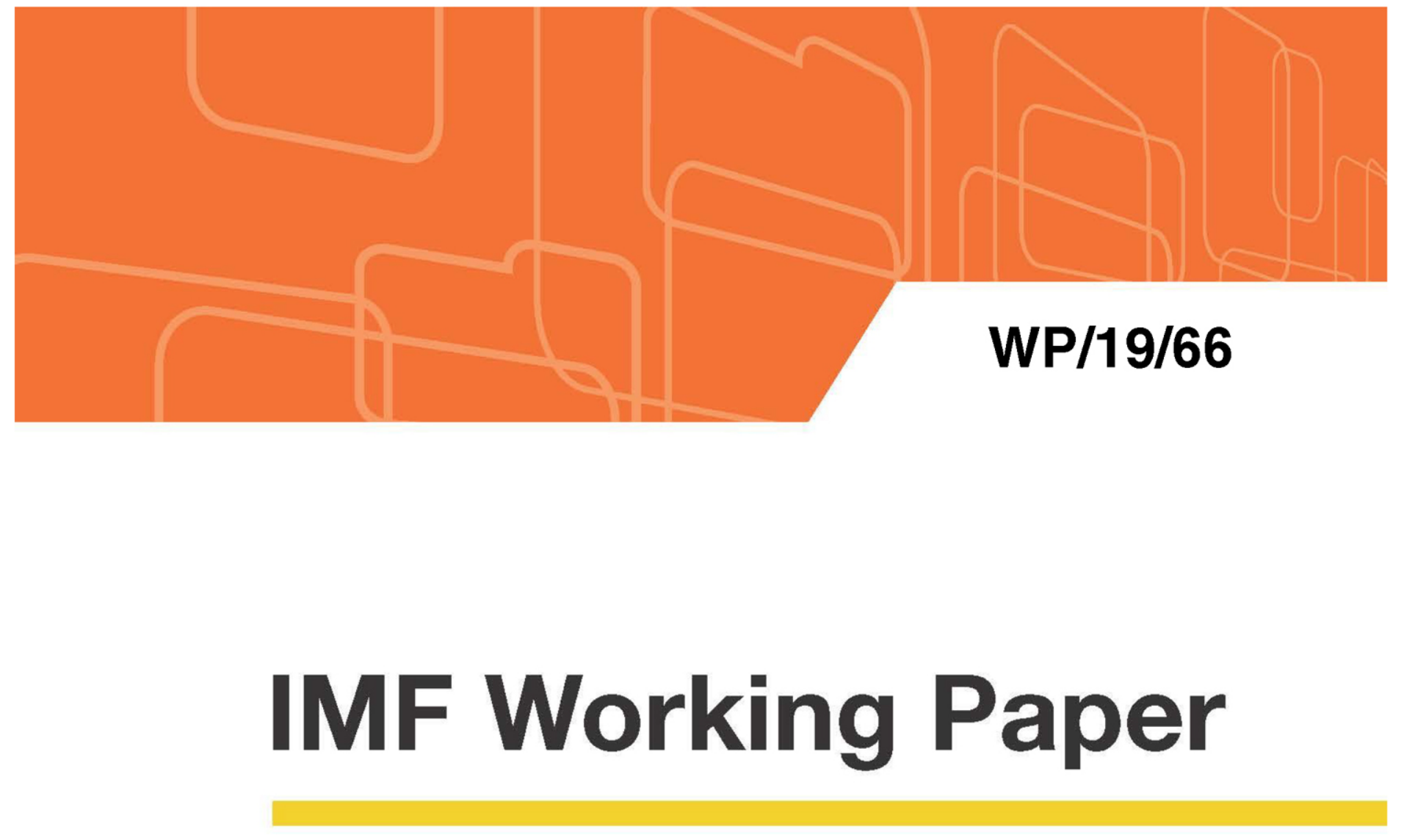

\title{
Digging Deeper-Evidence on the Effects of Macroprudential Policies from a New Database
}

by Zohair Alam, Adrian Alter, Jesse Eiseman, Gaston Gelos, Heedon Kang, Machiko Narita, Erlend Nier, and Naixi Wang

IMF Working Papers describe research in progress by the author(s) and are published to elicit comments and to encourage debate. The views expressed in IMF Working Papers are those of the author(s) and do not necessarily represent the views of the IMF, its Executive Board, or IMF management. 


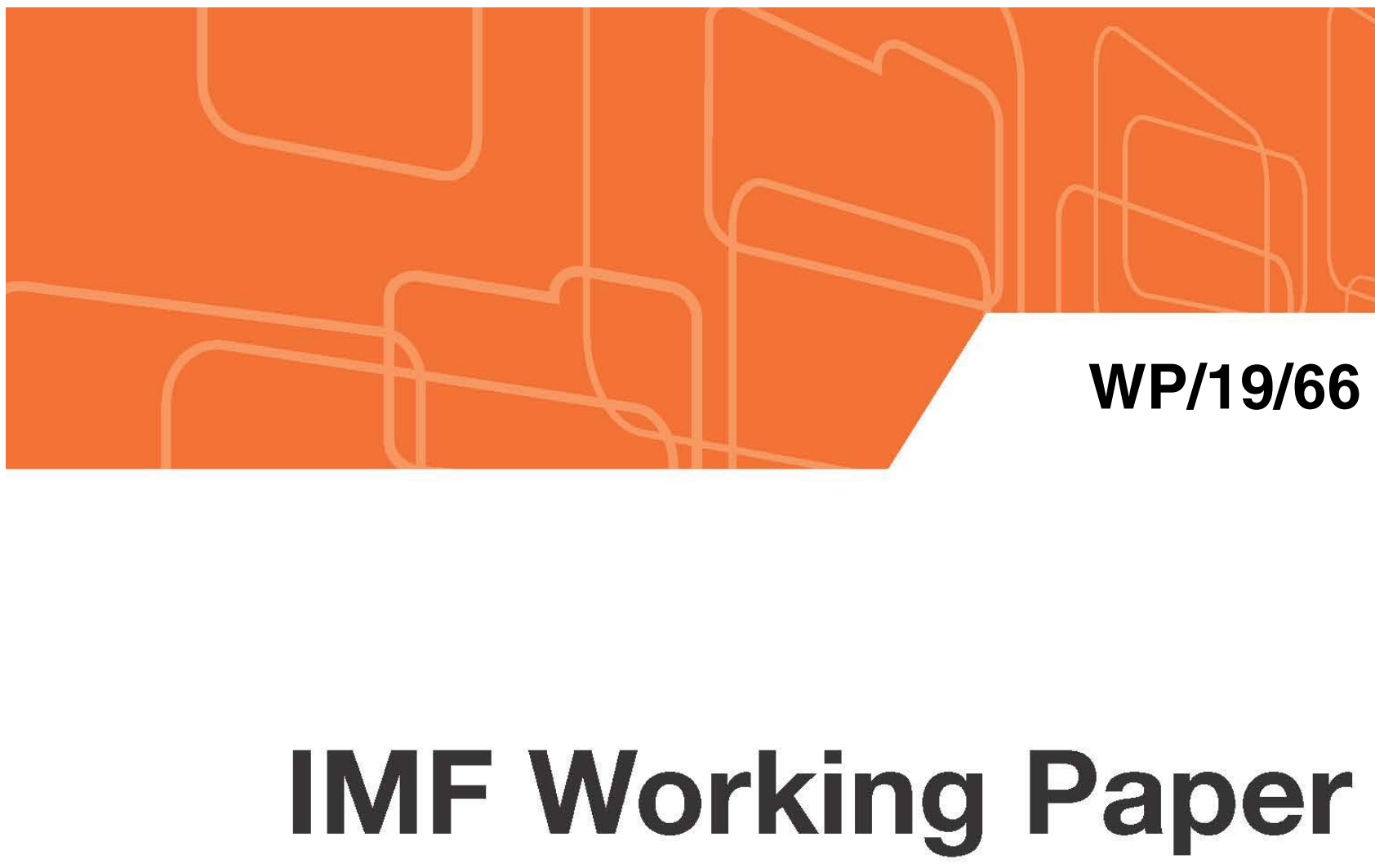

\section{Digging Deeper-Evidence on the Effects of Macroprudential Policies from a New Database}

by Zohair Alam, Adrian Alter, Jesse Eiseman, Gaston Gelos, Heedon Kang, Machiko Narita, Erlend Nier, and Naixi Wang

IMF Working Papers describe research in progress by the author(s) and are published to elicit comments and to encourage debate. The views expressed in IMF Working Papers are those of the author(s) and do not necessarily represent the views of the IMF, its Executive Board, or IMF management. 


\title{
IMF Working Paper
}

Monetary and Capital Markets Department

\section{Digging Deeper-Evidence on the Effects of Macroprudential Policies from a New Database}

\section{Prepared by Zohair Alam, Adrian Alter, Jesse Eiseman, Gaston Gelos, Heedon Kang, Machiko Narita, Erlend Nier, and Naixi Wang1}

March 2019

IMF Working Papers describe research in progress by the author(s) and are published to elicit comments and to encourage debate. The views expressed in IMF Working Papers are those of the author(s) and do not necessarily represent the views of the IMF, its Executive Board, or IMF management.

\begin{abstract}
This paper introduces a new comprehensive database of macroprudential policies, which combines information from various sources and covers 134 countries from January 1990 to December 2016. Using these data, we first confirm that loan-targeted instruments have a significant impact on household credit, and a milder, dampening effect on consumption. Next, we exploit novel numerical information on loan-to-value (LTV) limits using a propensityscore-based method to address endogeneity concerns. The results point to economically significant and nonlinear effects, with a declining impact for larger tightening measures. Moreover, the initial LTV level appears to matter; when LTV limits are already tight, the effects of additional tightening on credit is dampened while those on consumption are strengthened.
\end{abstract}

JEL Classification Numbers: E58, G28

Keywords: Macroprudential policy, loan-to-value ratios, propensity score Author's E-Mail Addresses: zohair.alam18@rotman.utoronto.ca, AAlter@imf.org, jesse.eiseman@gmail.com, GGelos@imf.org, HKang@imf.org, MNarita@imf.org, ENier@imf.org, and naixi.wang.mba2016@said.oxford.edu.

\footnotetext{
${ }^{1}$ The authors would like to thank Tobias Adrian, Chikako Baba, Luis Brandao Marques, Lucy Gornicka, Thomas Harjes, Dong He, Luis Jácome, Waesh Khodabocus, Ivo Krznar, David Lipton, Srobona Mitra, Futoshi Narita, Tjoervi Olafsson, Steven Phillips, Tigran Poghosyan, Ratna Sahay, Egon Zakrajsek, and participants in the seminars at the BIS, the BoE, the ECB, the ESM, and the IMF for useful comments. We are grateful to Wenyue Yang for her excellent research assistance, and to Sonia Maria Echeverri, Donna Tomas, and Janice Yi Xue for production assistance.
} 


\section{INTRODUCTION}

Despite considerable progress over the past years in assessing the effectiveness of macroprudential policies, many questions remain unanswered..$^{2}$ In particular, the literature has so far not fully succeeded in rigorously quantifying the effects of various macroprudential measures. This is due in part to a reliance on incomplete datasets in terms of the coverage of countries and measures. Moreover, previous research has mostly used dummy-type policy action indices, which do not allow for an estimation of quantitative effects of policies, a key issue for policymakers. In addition, endogeneity problems often hamper a proper assessment of macroprudential effects: macroprudential measures are usually taken in response to developments in credit and asset prices. If not properly addressed econometrically, this will tend to result in biased estimates (typically understating the effectiveness of macroprudential measures). ${ }^{3}$

In this paper, we aim to address some of these shortcomings by making progress on four fronts. First, we construct a new comprehensive database of macroprudential policies, combining information from various sources. Second, making use of the unique features of this database, we quantify the impact of a one-percentage-point change in LTV limits on household credit and house prices. Third, we address the endogeneity problem using propensity-score based methods to identify causal effects. Fourth, we make progress toward assessing side effects of macroprudential policies, by investigating their impact on private consumption. Assessing the effects on consumption is a first step toward a more comprehensive assessment of costs and benefits, which is outside of the scope of this paper. ${ }^{4}$

Our new database, the integrated Macroprudential Policy (iMaPP) database, has three advantages over other databases. First, it provides a comprehensive coverage in terms of instruments, countries, and time periods. It combines information from five existing databases, as well as the IMF's new Annual Macroprudential Policy Survey, and various additional sources, such as authorities' official announcements and IMF country documents. Second, the iMaPP database provides the average LTV limit prevailing in a given country at any given point in time, while most other databases only provide dummy-type policy action

\footnotetext{
${ }^{2}$ For a recent survey, see Galati and Moessner (2018).

${ }^{3}$ Studies trying to address this problem include Richter and others (2018), as well as some studies using micro data, such as Basten and Koch (2015) and Epure and others (2018).

${ }^{4}$ See Alpanda and Zubairy (2017), Svensson (2017), and Brandao and others (forthcoming) for a cost-benefit assessment of macroprudential policy as well as other policies.
} 
indicators. ${ }^{5}$ Third, the iMaPP database will be updated annually using information from the IMF's annual survey. ${ }^{6}$

Using the iMaPP database, we first broadly confirm results from the literature using standard methods and dummy-type indicators. In this analysis, we use panel regressions with data for 34 advanced and 29 emerging market economies for the period 1990 Q1-2016 Q4, and rely on a simple timing assumption to address endogeneity, as is common in the literature. Our results are in line with those in earlier studies: we find significant impacts of loan-targeted instruments on real credit to households, while the effects on house prices are weaker. ${ }^{7}$ In addition, we document a mild dampening effect on real household consumption.

Next, we exploit the new feature of our database - namely numerical information on the calibration of LTV limits - to quantify more precisely the impact of changes in these limits. To better identify the causal effects of LTV changes, we use a propensity-score-based method, which penalizes observations that are likely affected by reverse causality. Rich numerical information of the LTV limits also allow us to investigate nonlinear effects.

We find strong and nonlinear effects of LTV changes on household credit, and modest side effects on consumption. For the most common magnitude of LTV action in our sample - a tightening of less than 10 percentage points (ppts) - a one-ppt LTV tightening cumulatively reduces household credit growth by about 0.7 ppts after four quarters. For larger actions-a tightening by more than 10 ppts and less than 25 ppts-, the cumulative decline in household credit growth per one-ppt tightening is found to be smaller at 0.4 ppts. The side effects on consumption are less significant and of lesser magnitude, at around 0.1 ppts in both cases. The smaller per-unit effects on household credit of a larger LTV tightening could be driven by policy leakages, because a strong tightening could incentivize credit from abroad or from nonbank lenders, to which LTV limits may not apply.

We also find that the initial LTV level appears to matter for the tradeoff: when LTV limits are already tight, the effects on credit are milder, but the side effects on consumption stronger. This suggests that countries with tight LTV limits might be better off considering other macroprudential tools to complement existing measures.

The rest of the paper is structured as follows. Section II compares features of the iMaPP database to other similar databases and explains the construction of the average LTV limit

\footnotetext{
${ }^{5}$ See Appendix I Table 4. Although a few databases provide intensity-adjusted policy action indicators (Vandenbussche and others 2015 and Richter and others 2018), they do not provide the level information of the LTV limits, which the iMaPP database does.

${ }^{6}$ For a description of this survey see IMF (2018a).

${ }^{7}$ Many empirical studies provide the estimated effects per policy action, typically on credit growth and house prices (e.g., Igan and Kang 2011, Elliott and others 2013, Krznar and Morsink 2014, Kuttner and Shim 2016, Akinci and Olmstead-Rumsey 2018, Cerutti and others 2017, IMF 2017, and Poghosyan 2018).
} 
data. Section III revisits the standard regression analysis from the literature. Section IV quantifies the effects and the side-effects of a one ppt change in the LTV limits. Section V concludes.

\section{Integrated Macroprudential Policy Database}

\section{A. Key Features of the Database}

Our new macroprudential policy database integrates information from five major existing databases, and enriches this further with information from the IMF's new Annual Macroprudential Policy Survey, authorities' official announcements, and additional information from the BIS, FSB, and IMF. ${ }^{8}$ The integrated Macroprudential Policy Database (iMaPP) database provides (1) dummy-type indices of tightening and loosening actions for 17 macroprudential policy instruments and their subcategories; (2) detailed description of each policy action; and (3) country-level averages of the regulatory limits on loan-to-value (LTV) ratios at a monthly frequency. The database will be updated annually with information from the IMF's Annual Macroprudential Survey.

Whereas most existing databases focus on selected areas, the iMaPP database provides a comprehensive picture of macroprudential policy. ${ }^{910}$ It covers all instruments discussed in IMF (2014a,b), classifying them into 17 categories, for 134 countries from January 1990 to December 2016. It includes policy instruments that can be macroprudential in nature but also serve other purposes (such as capital flow management- and monetary policy measures), noting that macroprudential policy instruments can overlap with other policies (IMF 2014a, 2017). For reserve requirements, which are generally difficult to attribute unambiguously to macroprudential or monetary policy, the iMaPP database also provides a subcategory of differentiated reserve requirements by currency. See Appendix I Table 3 for the exact categories and their descriptions.

In addition to its wide coverage of instruments, countries, and time periods, the iMaPP database presents two distinct features: a granular breakdown of policy action indices by instruments, and the average LTV limit data. These features are discussed in more detail below.

However, there are also a few caveats. First, the iMaPP database does not cover every initial implementation, especially if instruments were introduced before the sample period starts.

\footnotetext{
${ }^{8}$ The integrated databases are Lim and others $(2011,2013)$, the Global Macroprudential Policy Instrument (GMPI) survey conducted by the IMF in 2013, Shim and others (2013), and the database by the European Systemic Risk Board (ESRB). See Appendix I for more information.

${ }^{9}$ Our definition of macroprudential policy is the use of primarily prudential tools to limit systemic risk, following IMF (2013a, 2013b, 2014a, 2014b), and IMF-FSB-BIS (2016).

${ }^{10}$ See Appendix I Table 4 for a comparison of the coverages in existing databases and in the iMaPP database.
} 
Second, the database only includes policy actions that have been verified through crosschecking with official documents. In some cases, data availability was constrained by language barriers and reporting differences.

\section{B. Granular Policy Action Indices}

Similarly to many existing databases (Appendix I Table 4), the iMaPP database provides dummy-type tightening and loosening indices. The dummy-type policy action indices take the value of 1 for tightening actions, -1 for loosening actions, and zero for no change. These indices are provided for 17 instruments at a monthly frequency. In addition, for selected instruments (e.g., capital requirements), our database provides the subcategories of general, household-sector, and corporate-sector measures to allow researchers to examine the effects of instruments that target particular sectoral exposures. These dummy indices are based on the effective date when it differs from the announcement date, because the effective date is more widely available.

The dummy-type indices are useful in several ways. First, focusing on the policy action and its direction, they extract information across diverse policies. Although calculating measures of policy intensity for all instruments would in principle be preferable, it would be difficult, and possibly not feasible, to construct such measures, given that the designs of instruments of interest are diverse. In fact, many policy instruments are implemented differently across countries, with different definitions of regulated variables, so that the numerical information provided in regulations is often not comparable across countries. Second, dummy indicators help characterize the use of macroprudential policy instruments and are useful to estimate the effects of macroprudential instruments per policy action, as in previous studies.

However, as discussed in the next subsection, these dummy-type indices only indicate the direction of a policy change, and lack information on the intensity of the change. For this reason, it is important to note that large changes in these indices do not necessarily indicate large changes in the policy instruments. It is possible, for instance, that some instruments are adjusted frequently but with small changes, while other instruments are adjusted less frequently but with large changes.

\section{Average LTV Limits}

We construct a quantitative measure of the regulatory limits on LTV ratios, one of the most widely used macroprudential instruments (Section II.D.). While some countries maintain such limits also for other types of loans (e.g., for car loans), we focus on those for real estate mortgage loans. Because countries tend to tailor the scope of their regulatory LTV limits to address specific vulnerabilities, they often have multiple regulatory LTV limits for different loan categories (e.g., loans for the primary residence, buy-to-let loans). To summarize the regulatory LTV limits prevailing in a given country, we take the simple average of regulatory LTV limits of all existing categories in that country, based on quantitative data contained in 
the text information of the iMaPP database. We construct this average LTV limit for 66 countries for each month from January 2000 to December 2016 (see Appendix II).

This average LTV limit series complements existing indices by providing quantitative information on both the level and changes of LTV limits. First, while most existing policy action indices only indicate the direction of a policy change (Appendix I Table 4), our average LTV limit series also informs about the intensity of the policy change. Second, the series provides information on the level of regulatory LTV limits, while existing intensityadjusted policy action indices do not (Vandenbussche and others 2015, and Richter and others 2018).

The average LTV limit can assist research and policy in many ways. Since the series closely tracks the prevailing limits on the LTV ratios, it allows us to quantify in greater detail the effects of changes in regulatory limits. In addition, because it contains the level information, it enables further examination of possible nonlinear effects of changes in regulatory limits (see Section IV).

One caveat is that the average LTV limit series may overstate the importance of LTV limits that only apply to a small group of loans. This is because the simple average gives equal weights to all categories, while regulatory changes affecting a large range of loans could be considered more important than those applied to a smaller range. One possible refinement could be to construct a weighted average of regulatory LTV limits, based on market shares of loan categories. However, such a weighted average requires time series of loan shares, which are not readily available in many countries.

\section{How has Macroprudential Policy Been Used?}

Before turning to the empirical analysis of the impact of macroprudential measures, we document how the use of such measures has grown globally over the recent past. The iMaPP database reveals that the number of economies that have used any macroprudential policy tool has been increasing steadily since 1990, before reaching a plateau around 2012. By that time, over 90 percent of economies in the sample had used at least one such tool (Figure 1). Interestingly, even before the global financial crisis, many had already implemented at least one macroprudential instrument -23 out of 36 advanced economies (AEs) and 61 out of 98 emerging market and developing economies (EMDEs) as of December 2006. 
Figure 1. Number of Economies that Have Used Macroprudential Policy

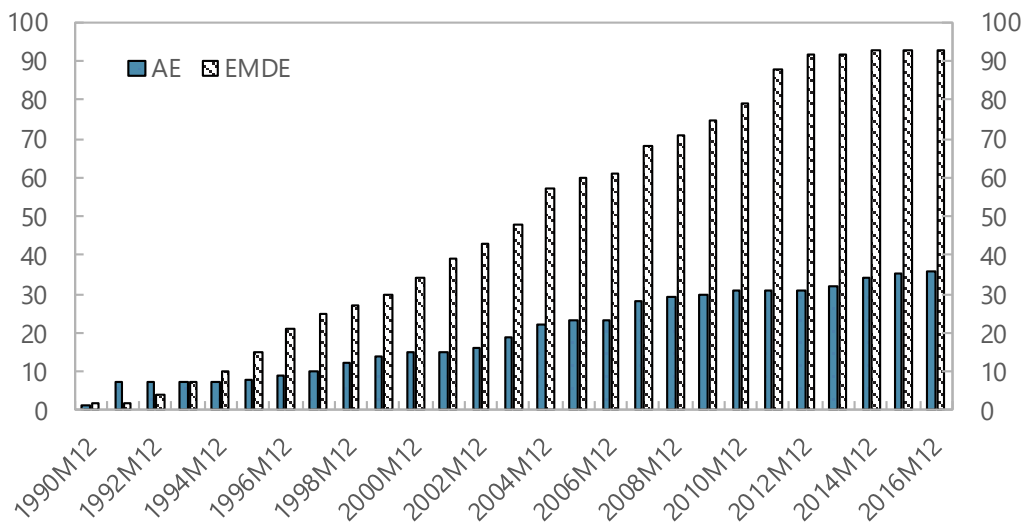

Sources: The iMaPP database (see Appendix I for the original sources) and authors' calculations. Note: The figure shows the number of economies that have used any macroprudential policy instrument (except for reserve requirements) at least once during the sample period. There are total 134 economies ( $36 \mathrm{AEs}$ and $98 \mathrm{EMDEs}$ ) in the iMaPP database. $\mathrm{AE}=$ advanced economies; and EMDE = emerging market and developing economies.

Turning to more recent usage, LTV limits emerge as the most popular tool among AEs, while limits on foreign exchange (FX) position are the tools most widely used among EMDEs (Figure 2). This may reflect differences in key risks - while AEs tend to be more concerned about housing sector vulnerabilities, EMDEs are more exposed to vulnerabilities from external shocks, including volatile capital flows and the potential systemic risks triggered by sharp changes in the exchange rate (Cerutti and others, 2017). On the other hand, some instruments are widely used in both AEs and EMDEs, such as capital requirements, LTV limits, and liquidity requirements.

Figure 2. Prevalence of Use by Instrument, December 2016
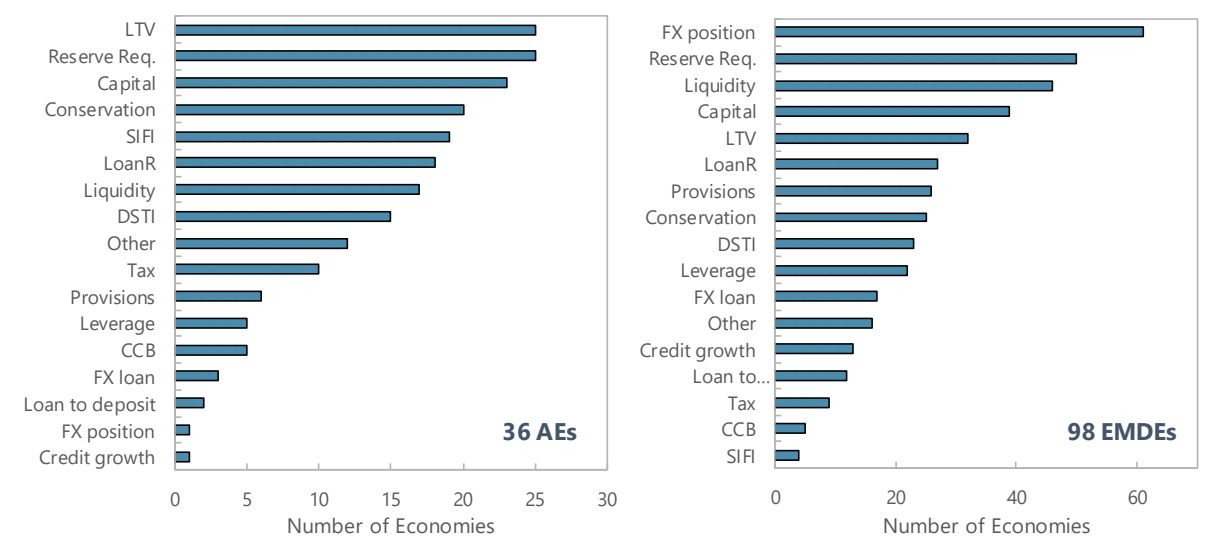

Sources: The iMaPP database (see Appendix I for the original sources) and authors' calculation. Notes: The figure shows the number of economies that have used the specified instrument as of December 2016. AE = advanced economies; and EMDE = emerging market and developing economies.

The frequency of policy actions varies across instruments (Figure 3). Focusing on the period after 2010, when most sample economies had implemented macroprudential instruments, we find that among AEs, the number of policy actions is largest for LTV limits, at 0.17 times per year on average (i.e., one in about six years). In EMDEs, the tool exhibiting the most policy 
actions are reserve requirements at 0.20 times per year-once in about five years. Some instruments have had very few actions in both groups, such as countercyclical buffers (CCB). Although the frequencies pertaining to individual instruments appear rather low, if we look at the policy actions across all instruments, then the frequency is much higher at 0.79 actions per year for AEs and 0.65 actions per year for EMDEs (i.e., at least one action in two years). In other words, policy makers are fairly active overall in using macroprudential policies, but the frequency varies considerably across economies (Kuttner and Shim, 2016).

Figure 3. Frequency of Policy Actions by Instrument, January 2010-December 2016
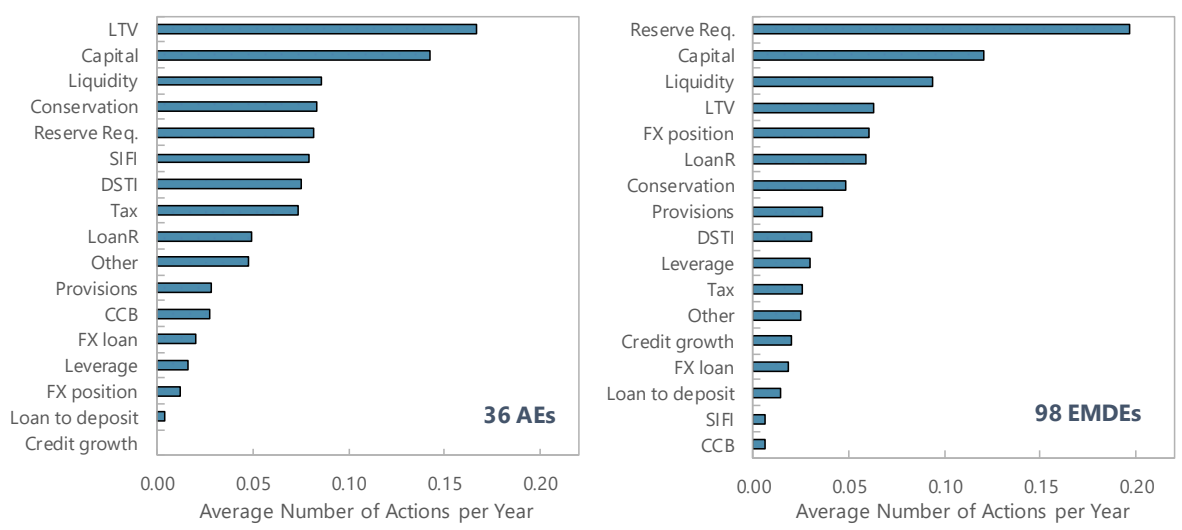

Source: The iMaPP database (see Appendix I for the original sources) and authors' calculation. Notes: For each instrument, we first take the country-level average number of adjustments, and then take the group-level average of the country-level average numbers of adjustments. The average numbers of actions are calculated for 2010M1-2016M12. AE = advanced economies; and EMDE = emerging market and developing economies.

Macroprudential policy tends to be tightened when household credit rises (Figure 4). For example, during the early 2000s, when credit growth was high, the net number of tightening actions across macroprudential instruments rose for both AEs and EMDEs. This suggests that macroprudential authorities actively take actions in response to credit developments, and underscores the importance of the reverse causality problem for empirical analysis.

The iMaPP database also provides quantitative information on regulatory LTV limits for 66 economies, revealing that they exhibit a wide range of values. For the 36 economies with an average LTV limit of less than 100 percent as of December 2016, the median is about 75 percent, but the distribution ranges from 47 to 95 percent (Figure 5, left panel). ${ }^{11}$ In particular, average limits in EMDEs appear tighter than those in AEs (Figure 5, right panel).

\footnotetext{
11 The average LTV limit is set to 100 when no regulatory limits exist. See Appendix II.
} 
Figure 4. Usage of Macroprudential Policies Over Time

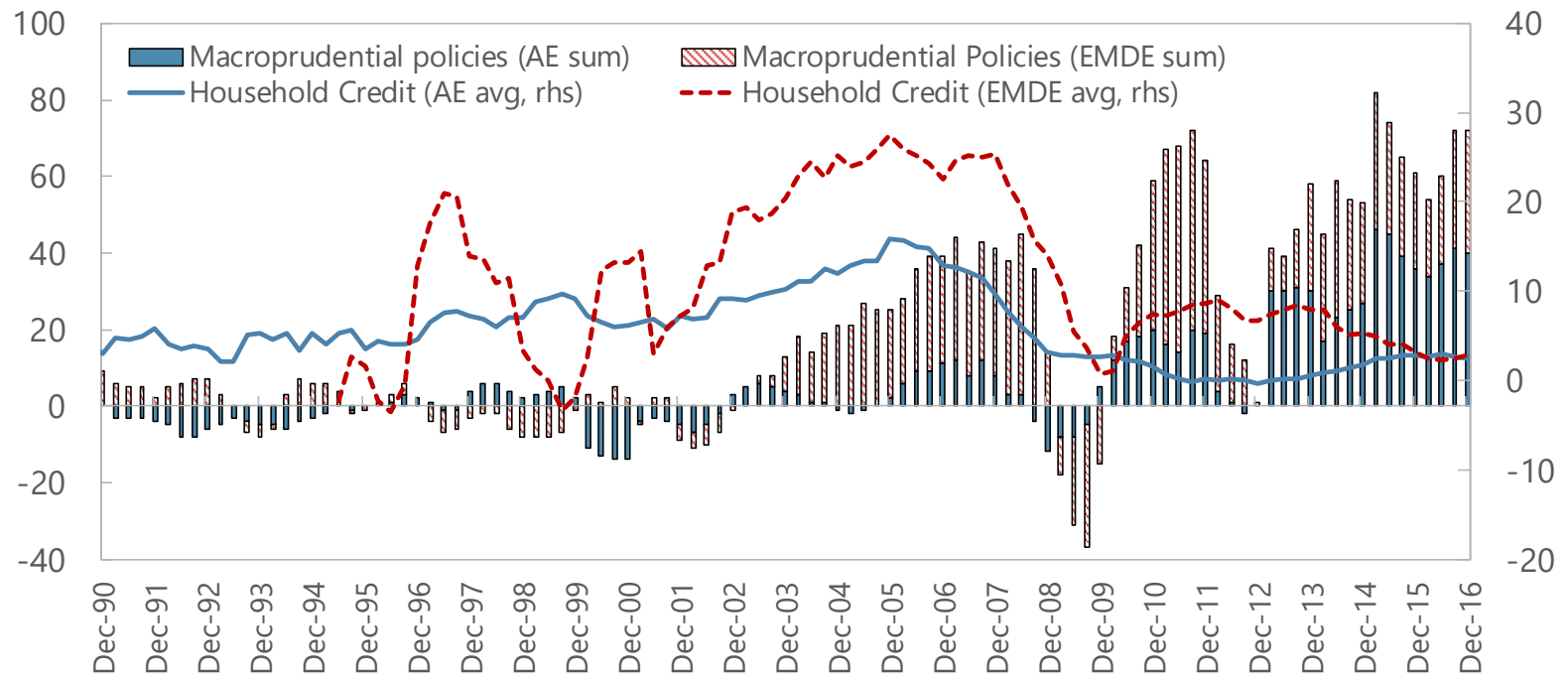

Sources: The iMaPP database, Bloomberg, BIS, OECD, others (see Appendix IV), and the authors' calculations.

Notes: This figure is based on the 63 countries for which quarterly data of household credit are available. The bars indicate the cumulative sum of the net number of tightening actions of any macroprudential policy instrument over the current and past three quarters and the lines indicate the average household credit growth. $A E=$ advanced economies; and EMDE = emerging market and developing economies.

Figure 5. Distribution of the Average LTV Limit, December 2016
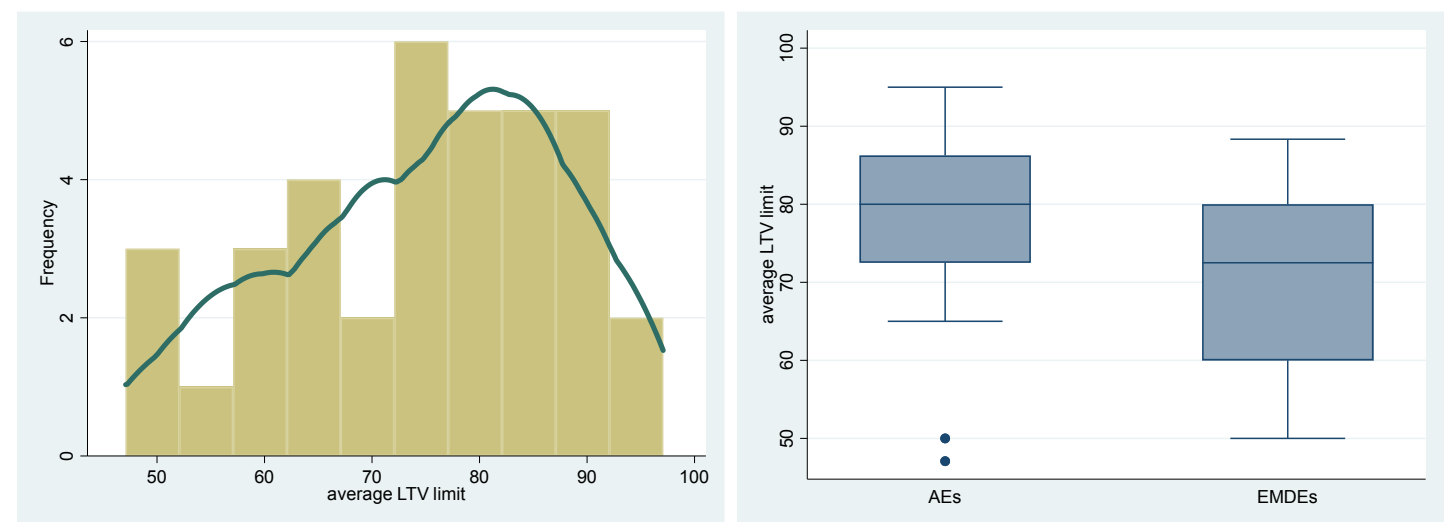

Sources: The iMaPP database (see Appendix I for the original sources) and authors' calculations.

Notes: The left panel shows the histogram of the average LTV limit of less than 100 percent, together with its kernel density estimate. The right panel shows the distributions for AEs and EMDEs. The box represents the inter-quartile interval, the inner line represents the median, and the outer lines represent the minimum and the maximum values.

The dots represent outliers. $\mathrm{AE}=$ advanced economies; and EMDE = emerging market and developing economies.

\section{REvisiting StANDARD REgRESSION ANALYSES}

\section{A. Empirical Strategy and Specifications}

In this section, we revisit questions that have been frequently asked in the literature: which macroprudential instruments has more potent effects in dampening household credit growth 
and house price increases? ${ }^{12}$ To address these questions, the iMaPP database not only offers more recent data, but also enables a comparison of the relative effects of different instruments (e.g., demand- vs. supply- side instruments, sector specific- vs. general measures). Furthermore, we also assess side effects of these measures in terms of dampening consumption growth and the growth of GDP, thereby adding to a very small literature that has looked at these side effects previously (IMF 2012, Richter and others 2018).

Building on the specifications in Arregui and others (2013) and Kuttner and Shim (2016), we estimate the following panel regression:

$$
\Delta_{4} C_{i, t}=\rho \Delta_{4} C_{i, t-1}+\beta \mathrm{MaPP}_{i, t-1}+\gamma \boldsymbol{X}_{i, t-1}+\alpha_{i}+\mu_{t}+\epsilon_{i, t},
$$

where $i$ is country and $t$ is time (quarter). ${ }^{13}$ The dependent variable, $\Delta_{4} C_{i, t}$, refers to the yearon-year growth rate of real household credit, real house prices, real private consumption, and real GDP, which are winsorized at one percent to address outliers.

The main independent variable, $\mathrm{MaPP}_{\mathrm{i}, \mathrm{t}}$, is the policy change indicator for the instrument or the instrument group $i$ at time $t$. This indicator records tightening actions $(+1)$, loosening actions ( -1$)$, and no changes ( 0$)$, and is cumulated over the past four quarters (and divided by four), to account for potential lagged effects. Since for many individual tools the variation is limited, we consider indices for instrument groups, including all, loan-targeted, demand, and supply measures, which are further subdivided into three categories, including general-, capital-, and loan-supply tools (see Appendix IV). To assess the effects of individual instruments, we focus on those with relatively more variation: loan-to-value limits (LTV), debt-service-to-income limits (DSTI), loan restrictions (LOANR), limits on bank credit growth (LCG), loan loss provisioning requirements (LLP), capital requirements (Capital), and tax measures (TAX).

The lagged dependent variable $\left(\Delta_{4} C_{i, t-1}\right)$ is included as a regressor to account for persistence. A vector $\boldsymbol{X}_{i, t-1}$ includes lagged macro control variables, such as real GDP growth and domestic real interest rates, as well as other macroprudential policies when regressions focus on the effect of specific measures. ${ }^{14}$ Time fixed effects $(\mathrm{t})$ capture time-

\footnotetext{
${ }^{12}$ In so doing, we assess the extent to which macroprudential policy is able to attain one of its intermediate objectives: to contain the build-up of systemic vulnerabilities by reducing procyclical feedback between credit and asset prices and containing unsustainable increases in leverage. A second, and at least equally important objective is to increase the resilience of borrowers and lenders to aggregate shocks (see further IMF 2013, IMF 2014a and IMF-FSB-BIS 2016). This resilience objective has not so far been the focus of the literature, even though it is arguably at least as important. We leave empirical investigation of the extent to which macroprudential policy can attain the resilience objective for future research.

${ }^{13}$ Due to the frequency of some control variables, the macroprudential instrument indices are aggregated into a quarterly frequency.

${ }^{14}$ As a robustness check, changes in domestic real interest rates are considered as an additional control. Our results point to similar findings both in terms of magnitude and statistical significance.
} 
varying common factors such as global risk aversion, while country fixed effects $\left(\alpha_{\mathrm{i}}\right)$ capture time-invariant country-specific factors such as institutional characteristics.

The identification of macroprudential policy effects is based on a timing assumptionmacroprudential policy does not affect macro-financial variables (e.g., credit growth) within the same quarter. This is a rather strong assumption, and the estimated coefficient of $\mathrm{MaPP}_{\mathrm{i}, \mathrm{t}-1}$ would be subject to the attenuation bias if the timing assumption did not hold (see further Appendix III), even as this is the typical approach taken in previous studies. We will return to this issue in Section IV.

The model is estimated for 63 countries (34 AEs and 29 EMDEs), where quarterly macro variables are available, over the period 1991 Q1 to 2016 Q4, using panel regressions with fixed effects. See Appendix IV for the list of countries, variable descriptions and sources, and their summary statistics.

\section{B. The Effects of Policy Actions}

We initially focus on the impact of aggregated indices of macroprudential policy on household credit growth (Table 1, columns 1-3). A tightening of any macroprudential measure (captured by the overall MaPP index) is, on average, associated with a decline in household credit growth of 0.8 percentage points (ppts), when all countries are considered. ${ }^{15}$ The effects on household credit growth are typically more statistically significant and generally larger in EMDEs. For these countries, the impact amounts to a decline of almost 1.5 ppts.

Looking at sub-indices, loan-targeted tools are found to robustly affect household credit growth across all country groups. The loan-targeted tools include the LTV and DSTI limits (i.e., the "demand-side" tools) and those constraining bank loan supply (i.e., the "supplyloans" tools), such as restrictions on credit growth and loan loss provisions. Among loantargeted measures, the supply-side measures are found to have larger effects on household credit than the demand-side measures. These effects are economically significant: a tightening event of loan supply tools is associated with an approximately 3 ppts decline in household credit growth after four quarters in both AEs and EMDEs. Other supply-side tools are found to have less potent effects in containing credit growth ("supply-general" and "supply-capital" in Table 1), in line with previous studies, and consistent with the idea that their main objective is to strengthen the resilience of the financial system.

\footnotetext{
15 The unconditional household credit growth averages about 8 ppts per year when all countries are considered. In EMDEs, it averages 11.6 ppts, while in AEs household credit increases yearly by 5.6 percent. See Appendix IV Table 3.
} 


\section{Table 1. Summary: The Effects of Macroprudential Policies on Household Credit and House Prices}

(1)

(2)

(3)

(4)

Real House Prices (yoy growth)

\begin{tabular}{|c|c|c|c|c|c|c|}
\hline \multirow{2}{*}{$\begin{array}{l}\text { Dependent Variable: } \\
\text { Group: }\end{array}$} & \multicolumn{3}{|c|}{ Real Household Credit (yoy growth) } & \multicolumn{3}{|c|}{ Real House Prices (yoy growth) } \\
\hline & ALL & $\mathrm{AE}$ & EMDE & ALL & $\mathrm{AE}$ & EMED \\
\hline MaPP index (all tools) & $-0.842^{\star * *}$ & -0.257 & $-1.388^{* * *}$ & -0.0877 & $-0.898^{\star *}$ & 0.0619 \\
\hline Loan-Targeted & $-1.883^{* * *}$ & $-1.043^{* *}$ & $-2.925^{\star * *}$ & $-1.066^{* *}$ & $-1.667^{\star *}$ & -0.615 \\
\hline Demand & $-1.994^{* * *}$ & -0.607 & $-4.926^{* * *}$ & $-1.406^{* *}$ & $-2.049^{* *}$ & -0.213 \\
\hline Supply-All & $-0.824^{*}$ & 0.395 & $-1.511^{* * *}$ & 0.253 & 0.0116 & 0.00789 \\
\hline Supply- Loans & $-2.931^{* * *}$ & $-3.028^{* *}$ & $-3.005^{\star *}$ & -1.191 & -1.970 & -1.191 \\
\hline Supply- General & -0.602 & 0.958 & $-1.354^{*}$ & 0.485 & 0.0313 & 0.175 \\
\hline Supply- Capital & -1.009 & 0.221 & $-1.959^{*}$ & 0.270 & 0.0689 & 0.459 \\
\hline dsti & $-2.648^{* * *}$ & -1.231 & $-6.173^{* *}$ & -1.455 & -3.167 & 2.537 \\
\hline Itv & $-2.557^{\star \star}$ & -0.654 & $-5.797^{\star * *}$ & $-1.952^{* * *}$ & $-2.627^{* * *}$ & -1.020 \\
\hline $\operatorname{tax}$ & -0.988 & -1.514 & -0.860 & -0.597 & $-5.159^{* *}$ & $3.235^{\star * *}$ \\
\hline $\operatorname{lcg}$ & -4.620 & -2.142 & $-6.562^{*}$ & -1.965 & -0.0586 & -2.436 \\
\hline$\| p$ & $-5.865^{* * *}$ & -4.161 & $-6.656^{* * *}$ & $-2.987^{* *}$ & -1.510 & $-4.529^{* *}$ \\
\hline loanr & $-3.489^{* *}$ & $-4.592^{* *}$ & -2.885 & -1.385 & $-4.164^{*}$ & -0.262 \\
\hline capital & -1.091 & 0.0547 & -1.803 & 0.304 & -0.157 & 0.582 \\
\hline Observations & 4,492 & 2,858 & 1,634 & 4,111 & 2,780 & 1,331 \\
\hline $\mathrm{N}$ (countries) & 63 & 34 & 29 & 55 & 34 & 21 \\
\hline R-squared (avg) & 0.884 & 0.873 & 0.903 & 0.812 & 0.846 & 0.786 \\
\hline
\end{tabular}

Sources: The iMaPP database, Bloomberg, BIS, OECD, others (see Appendix IV), and authors' estimation.

Notes: The table reports the cumulative effects of the specified macroprudential tightening after four quarters, obtained by the fixed effects (FE) estimation. Each MaPP index/policy is considered individually. "dsti"= limits to the debt-service-to-income ratio, "Itv"= limits to the loan-to-value ratio, "tax"= tax measures, "Icg"= limits to credit growth, "Ilp"= loan loss provisions, "loanr"=loan restrictions, and "capital"=capital requirements. "MaPP index" is the sum of dummies for all of 17 categories. "Loantargeted" group consists of the "Demand" and the "Supply-loans" instruments. "Demand": LTV and DSTI. "Supply-loans": Icg, Ilp, loanr, limits to the loan to deposit ratio, and limits to foreign currency loans. "Supply-general": reserve requirements, liquidity requirements, and limits to FX positions. "Supply-capital": leverage, countercyclical buffers, conservation buffers, and capital requirements. See Appendix I Table 3 for the definitions of instruments. For each country group, R-squared is computed as the average of the individual regressions. $\mathrm{AE}=$ advanced economies; and $\mathrm{EMDE}=$ emerging market and developing economies.

Next, we examine the impact of individual macroprudential measures. Regarding the demand-side tools, the tightening of both DSTI and LTV limits are robustly and negatively associated with household credit. The estimated ppt declines are greater in EMDEs, where one tightening (loosening) action moderates (raises) household credit by about 6 percent for these tools. ${ }^{16}$ These results corroborate the findings of Cerutti and others (2017) and Kuttner

\footnotetext{
${ }^{16} \mathrm{~A}$ few studies examine whether the effects are asymmetric between tightening and loosening measures, but the results are mixed, probably due to the small sample of loosening events. While Kuttner and Shim (2016) find stronger effects of tightening actions for 57 countries, Poghosyan (2019) reports the opposite for $28 \mathrm{EU}$ countries. IMF $(2012 \mathrm{a}, \mathrm{b})$ finds limited evidence for asymmetric effects for 36 countries.
} 
and Shim (2016) who also find significant effects for demand-side tools. ${ }^{17}$ We also find that tightening actions concerning loan loss provisions and loan restrictions tend to slow household credit growth.

The effects of macroprudential policies on house prices are mostly weaker (Table 1, columns 4-6), in line with most existing studies. ${ }^{18}$ There is some evidence that loan-targeted macroprudential measures can mitigate house price growth, and these effects tend to be stronger in AEs, where housing markets tend to be more developed. They reduce house price growth by about one ppt for the entire sample and by 1.7 ppts for AEs. Among loan-targeted measures, demand-targeted policy actions appear to be the most potent ones.

Interestingly, in AEs, tax-related macroprudential policies, such as stamp duties on real estate transactions appear to dampen house price growth by a substantial $5 \mathrm{ppt}$, even as their impacts on household credit growth is statistically insignificant. One interpretation of this result is that tax-related measures can have an immediate effect on real estate valuations even if they do not materially affect transactions or credit developments. Another is that some of these tax measures are designed to deter foreign demand from pushing into local real estate markets. This foreign demand tends to be delinked from the domestic credit market, since most of those transactions are conducted with cash and do not involve domestic borrowing.

Turning to the side-effects, our goal is to quantify the consequences of macroprudential policies on macroeconomic outcomes such as a slowdown in private consumption (see Table 2, columns 1-3) and real GDP growth (Table 2, columns 4-6). These consequences are referred to as "side effects," since they would not typically be the policy objective of macroprudential action (IMF 2012, Richter and others, 2018).

In the short run, macroprudential policies can be expected to weigh on consumption and growth for a couple of reasons. First, since they are typically designed to contain credit growth, they should slow investment and consumption. Second, to the extent that macroprudential policies dampen growth in asset prices, ensuing wealth effects are expected to reduce consumption and investment. Third, some tools, especially those working on the demand side (i.e., LTV and DSTI limits) may lead households to increase savings, in order to become eligible for a loan, again thereby reducing consumption.

\footnotetext{
${ }^{17}$ Other studies, using different data and methods, also show that tighter LTV and DSTI limits reduce household credit growth (e.g., Lim and others 2011; Arregui and others 2013; Crowe and others 2013; Krznar and Morsink 2014; and Jácome and Mitra 2015). Also, Darbar and Wu (2015) and IMF (2018c) show that a tightening of LTV limits reduced the share of high LTV loans in several advanced economies, suggesting an improvement of housing loans.

${ }^{18}$ Kuttner and Shim (2016) and Cerutti and others (2017) also find weaker effects on house prices compared to those on credit growth, while other studies provide evidence for contractionary effects on house prices (e.g., Vandenbussche and others 2015 and Akinci and Olmstead-Rumsey, 2018). IMF (2014b) notes that if strong housing demand and house price growth are financed directly by foreign cash inflows (bypassing domestic credit intermediation), it can be difficult to contain house price growth using sectoral macroprudential tools.
} 


\section{Table 2. Summary: The Side Effects of Macroprudential Policies on Private Consumption and GDP Growth}

\begin{tabular}{|c|c|c|c|c|c|c|}
\hline \multirow{3}{*}{$\begin{array}{l}\text { Dependent Variable: } \\
\text { Group: }\end{array}$} & (1) & $(2)$ & (3) & (4) & (5) & (6) \\
\hline & \multicolumn{3}{|c|}{ Real Consumption (yoy growth) } & \multicolumn{3}{|c|}{ Real GDP (yoy growth) } \\
\hline & ALL & $\mathrm{AE}$ & EMDE & ALL & $\mathrm{AE}$ & EMDE \\
\hline MaPP index (all tools) & -0.150 & -0.170 & -0.197 & 0.0466 & -0.0414 & 0.0427 \\
\hline Loan-Targeted & $-0.999^{* * *}$ & $-0.888^{\star *}$ & -0.914 & -0.0729 & -0.119 & -0.0582 \\
\hline Demand & $-0.649^{*}$ & $-0.527^{*}$ & -0.607 & -0.112 & -0.131 & -0.138 \\
\hline Supply-All & 0.0964 & 0.476 & -0.176 & 0.0885 & -0.0131 & 0.0737 \\
\hline Supply- Loans & $-2.006^{* *}$ & $-2.707^{\star *}$ & -1.370 & -0.0633 & -0.179 & -0.0301 \\
\hline Supply- General & 0.359 & $0.998^{*}$ & 0.0276 & 0.164 & -0.0314 & 0.163 \\
\hline Supply- Capital & -0.137 & -0.0225 & -0.453 & -0.118 & 0.103 & -0.360 \\
\hline dsti & -1.054 & -1.066 & -1.569 & -0.191 & -0.207 & -0.134 \\
\hline Itv & $-0.778^{*}$ & -0.573 & -0.378 & -0.127 & -0.163 & -0.176 \\
\hline $\operatorname{tax}$ & -1.446 & -1.685 & $-1.394^{* *}$ & -0.0490 & -0.315 & 0.146 \\
\hline $\operatorname{lcg}$ & 0.638 & 0.513 & 0.377 & 0.197 & $-0.800^{* *}$ & 0.513 \\
\hline$\| p$ & -2.153 & $-2.193^{*}$ & -2.176 & -0.482 & -0.614 & -0.482 \\
\hline loanr & $-3.841^{* * *}$ & $-4.267^{* *}$ & -2.486 & 0.00843 & -0.0258 & -0.0511 \\
\hline capital & -0.0605 & 0.175 & -0.318 & 0.0150 & 0.162 & -0.147 \\
\hline Observations & 4,639 & 2,863 & 1,776 & 5,416 & 3,125 & 2,291 \\
\hline $\mathrm{N}$ (countries) & 55 & 31 & 24 & 64 & 34 & 30 \\
\hline R-squared (avg) & 0.775 & 0.771 & 0.792 & 0.912 & 0.931 & 0.900 \\
\hline
\end{tabular}

Sources: The iMaPP database, Bloomberg, BIS, OECD, others (see Appendix IV), and the authors' estimation.

Notes: The table reports the cumulative effects of the specified macroprudential tightening after four quarters, obtained by the fixed effects (FE) estimation with the timing assumption. Each MaPP index/policy is considered individually. "dsti"= limits to the debt-service-to-income ratio, "Itv"= limits to the loan-to-value ratio, "tax"= tax measures, "Icg"= limits to credit growth, "llp"= loan loss provisions, "loanr"=loan restrictions, and "capital"=capital requirements. "MaPP index" is the sum of dummies for all of 17 categories. "Loan-targeted" group consists of the "Demand" and the "Supply-loans" instruments. "Demand": LTV and DSTI. "Supply-loans": Icg, Ilp, loanr, limits to the loan to deposit ratio, and limits to foreign currency loans. "Supply-general": reserve requirements, liquidity requirements, and limits to FX positions. "Supply-capital": leverage, countercyclical buffers, conservation buffers, and capital requirements. For each country group, R-squared is computed as the average of the individual regressions. For more details see Appendix Tables 9 and 11. AE = advanced economies; and EMDE = emerging market and developing economies.

In general, we find limited evidence of side effects on consumption. However, loan-targeted policy actions, especially those targeting the supply of bank loans, are negatively associated with private consumption growth. On average, a tightening of loan supply measures can reduce consumption growth by up to about 2 ppts, when all loan supply measures are combined in an index. The negative effects are stronger in AEs, where the share of consumption financed by credit may be larger than in EMDEs.

At the individual level, LTV limits and loan restrictions are found to reduce private consumption growth cumulatively by roughly 0.8 and 3.8 ppts after one year, respectively. Focusing on AEs, the effects of loan loss provisions and loan restrictions are negative and 
statistically significant, with the magnitude of the effects ranging between 2.2 and 4.3 ppts. For EMDEs, the largest side effect is found for tax-related macroprudential policies, which reduce private consumption growth by 1.4 ppts.

When considering real GDP growth, the estimated side effects are weaker and generally not statistically significant (Table 2, columns 4-6). The only exception is the limits on credit growth in AEs, which reduce real GDP growth by 0.8 ppts (Table 2, column 5).

In summary, we confirm that loan-targeted policy actions have significant effects on household credit growth, while the effects on house prices are somewhat weaker.

Contributing to a less explored strand of the literature, we also assess the short-term sideeffects of macroprudential policy on consumption and find these effects to be relatively mild. Among the policy instruments considered, demand-side tools, such as DSTI and LTV limits, appear to be fairly efficient in the sense that they exhibit sizable effects on credit growth with more modest side-effects on consumption, although a welfare analysis is needed for a more comprehensive cost-benefit assessment. We return to this issue below, in the context of the estimation of effects of quantitative changes in the policy instrument.

\section{Robustness Checks}

Our results could be biased for several reasons. First, the estimated policy effects would be biased toward zero in the presence of reverse causality if the timing assumption of no contemporaneous policy effects did not hold (Appendix III). Second, although the iMaPP database includes more than one thousand policy actions, several tools are only utilized by a handful of countries. Third, the inclusion of the lagged dependent variable as a regressor could lead to a bias in the fixed-effect estimator (Nickell 1981), although the bias would be minimal given the long sample period. ${ }^{19}$ To assess the validity of our findings, various robustness checks are explored in Appendix V, including the system GMM panel estimates, while the reverse causality issue is addressed more formally in the next section's analysis using a propensity-score-based method. The appendix also presents our extended analysis using quantile regression, which shows that macroprudential policies tend to reduce the incidence of credit booms.

\section{Quantifying the Effects of Percentage-Point Changes in the LTV Limits}

\section{A. Propensity-Score Based Approach}

In this section, we move beyond the analysis typically presented in the literature in two ways. First, we quantify the effects of a one-percentage-point change in the LTV limit using our new indicator, the average LTV limit. Second, we examine whether the effects are non-

\footnotetext{
${ }^{19}$ The time dimension in our panel estimation covers on average 71 periods, ranging from a minimum of 19 to a maximum of 104 .
} 
linear - that is, whether the effects of a one-percentage-point tightening are different, depending on the size of the overall amount of tightening and the starting level of the LTV limits. Third, we undertake additional efforts to identify causal effects, employing a propensity-score based approach.

The empirical challenge in identifying the causal effects of macroprudential policy is reverse causality, which could lead to endogeneity biases in estimation. Reverse causality is likely to be a problem in our context because the LTV limits are more likely to be tightened during periods of high credit growth (Figure 4). Therefore, estimations that do not address the issue are likely to be subject to attenuation bias. The typically used timing assumption (Section III) is unlikely to hold generally. ${ }^{20}$

We employ an inverse propensity-score weighted (IPW) estimator specifically designed for our purposes. The use of propensity score methods is relatively new in the macroeconomics literature ${ }^{21}$ but widely spread in biostatistics. The IPW estimator identifies the causal effects of macroprudential policy by penalizing those observations that are likely to be affected by reverse causality. While there are many variants of IPW estimators, we use the Augmented IPW (AIPW) estimator, which achieves the smallest asymptotic variance in the class of the "doubly-robust" estimators. ${ }^{22}$

Specifically, the AIPW estimation of the effects of changes in LTV limits is conducted in three stages. In the first stage, an ordered logit model is estimated to obtain the propensity score - the probability of changing the LTV limit. The dependent variable is an ordered policy action indicator taking on the values $\{-20,-10,0,10,20\}$, which represents the buckets in which the change in the LTV limit ( $\triangle \mathrm{LTV}$ ) is grouped into (Table 3 ), and the regressors are macro variables that may influence policy actions (see Appendix VI for details). In the second stage, outcomes (e.g. credit growth) for each bucket of $\Delta$ LTV are predicted using macroeconomic variables to correct for unobserved outcomes. Then, in the third stage, the average treatment effect (ATE) on the outcome (e.g., credit growth) is estimated for each bucket of $\Delta \mathrm{LTV}$, using (1) the estimated inverse propensity-scores to put more (less) weights on the observations that are less (more) likely to be affected by reverse causality; and (2) the predicted outcomes in lieu of unobserved outcomes in the unrealized

\footnotetext{
${ }^{20}$ Appendix III shows the attenuation bias in a typical regression model in the literature when the timing assumption does not hold.

${ }^{21}$ Jordà and Taylor (2016), Angrist and others (2016), and Richter and others (2018) apply propensity-score based methods to estimate the effects of fiscal austerity, monetary policy, and macroprudential policy.

${ }^{22}$ It is the class of the estimators of the average treatment effect (ATE) that involves estimating both a treatment model and an outcome model; and that has a "doubly-robust" property - consistency of the estimated ATE only requires either the treatment model or the outcome model to be correctly specified. See, for example, Robins and others (1994) and Lunceford and Davidian (2004).
} 
states. ${ }^{23}$ To obtain the estimated ATE of a one-percentage-change in the LTV limit, the estimated ATE is rescaled by the average $\triangle \mathrm{LTV}$ for each bucket. The AIPW estimation is conducted with panel data of 58 countries over the period 2000 Q1 to 2016 Q4. The ATEs are reported only for tightening groups with more observations.

\section{Table 3. Summary Statistics of the Change in the Average LTV Limit by Group}

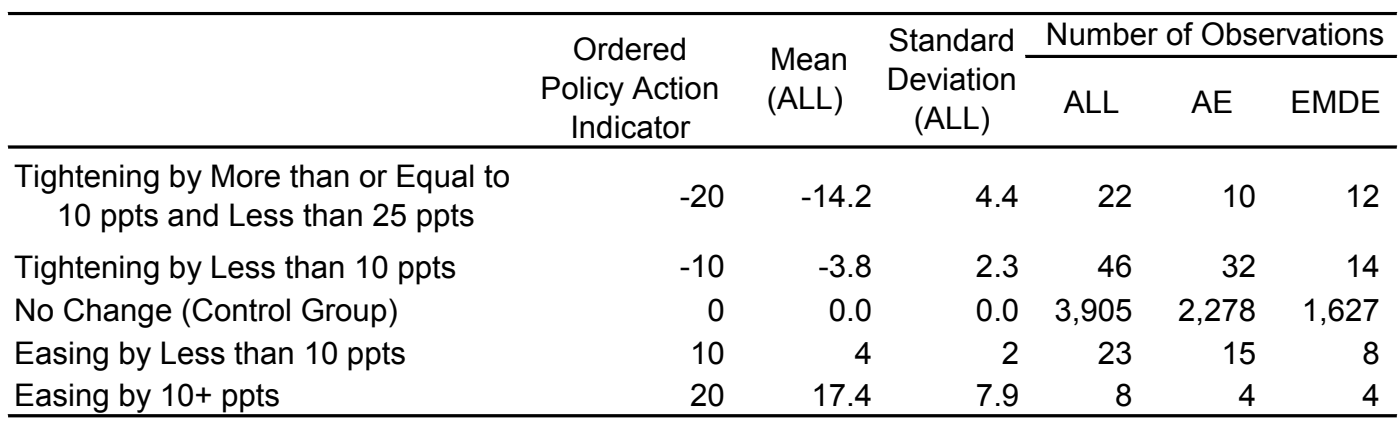

Sources: The iMaPP database (see Appendix I for the original sources) and the authors' calculation. Notes: The table shows the summary statistics of the change in the average LTV limit for the four treatment groups and for the control group. Observations with $\Delta$ LTV less than or equal to -25 ppts are excluded for the estimation to mitigate the influence of outliers. $\mathrm{AE}=$ advanced economies; and $\mathrm{EMDE}=$ emerging market and developing economies.

For comparison, we also estimate the effect of a one-percent-point LTV tightening using standard panel regression methods, based on the timing identification assumption (Appendix VII). When we examine whether results differ across subsamples, such as advanced- versus emerging market economies, we revert to the panel regression methods, since the AIPW estimation, which is already based on a bucketing approach, requires a relatively large number of observations.

\section{B. The Effects of One-Percentage-Point Change in LTV Limits}

The AIPW estimation results indicate strong and nonlinear effects of a one-ppt LTV tightening on household credit. For a tightening of less than $10 \mathrm{ppts}$, the cumulative decline in real household credit growth after four quarters is estimated at 0.65 ppts per one-ppt LTV tightening, while it is estimated at -0.36 ppts for a larger tightening by more than or equal to 10 ppts and less than 25 ppts (Panel 1of Figure 6). ${ }^{24}$ Interestingly, the estimated effects per

\footnotetext{
${ }^{23}$ Please note that actual outcomes are only observed in a realized state-e.g., for countries that tighten their LTV limits, we cannot observe their outcome (e.g., credit growth) in the hypothetical scenario where they did not tighten (i.e., the unrealized state).

${ }^{24}$ The average effect on household credit growth of any tightening measure is estimated at -0.31 ppts (compared to -0.16 ppts in the FE regression), based on the AIPW estimation with three buckets (i.e., the tightening, loosening, and control groups). Please note that, considering the observed nonlinearity, these linear models would likely be mis-specified. The linear model estimates are broadly comparable with the estimates by Richter and other (2018), although caution is needed when comparing the results because the definition of LTV limits differs - their LTV indicator includes loan prohibitions while ours do not. Their estimated effect on household credit growth ranges from -0.58 to -0.18 ppts - the per-action estimate of -4.1 ppts divided by the average LTV change per tightening of $7.1 \mathrm{ppts}$ (with scope adjustments) or 22.5 ppts (without scope adjustments).
} 
one-ppt tightening are diminishing with respect to the size of the LTV adjustment. The relatively smaller effects of larger tightening could be due to policy leakage (e.g., regulatory arbitrage) effects. For example, if the LTV limits only cover domestic bank loans, a strong tightening could incentivize arbitrage and thus increase non-bank credit or credit from abroad when these loans are not covered by the limit, offsetting the policy effects on domestic bank credit (e.g., IMF 2013 and 2014, and IMF-FSB-BIS, 2016). The magnitude of the estimated effects depends on the choices of thresholds for tightening groups, partly due to the nonlinearity but for large LTV changes also due to the relatively limited number of observations and the influence of outliers.

Figure 6. Causal Effects of One Percentage Point Tightening in LTV limits
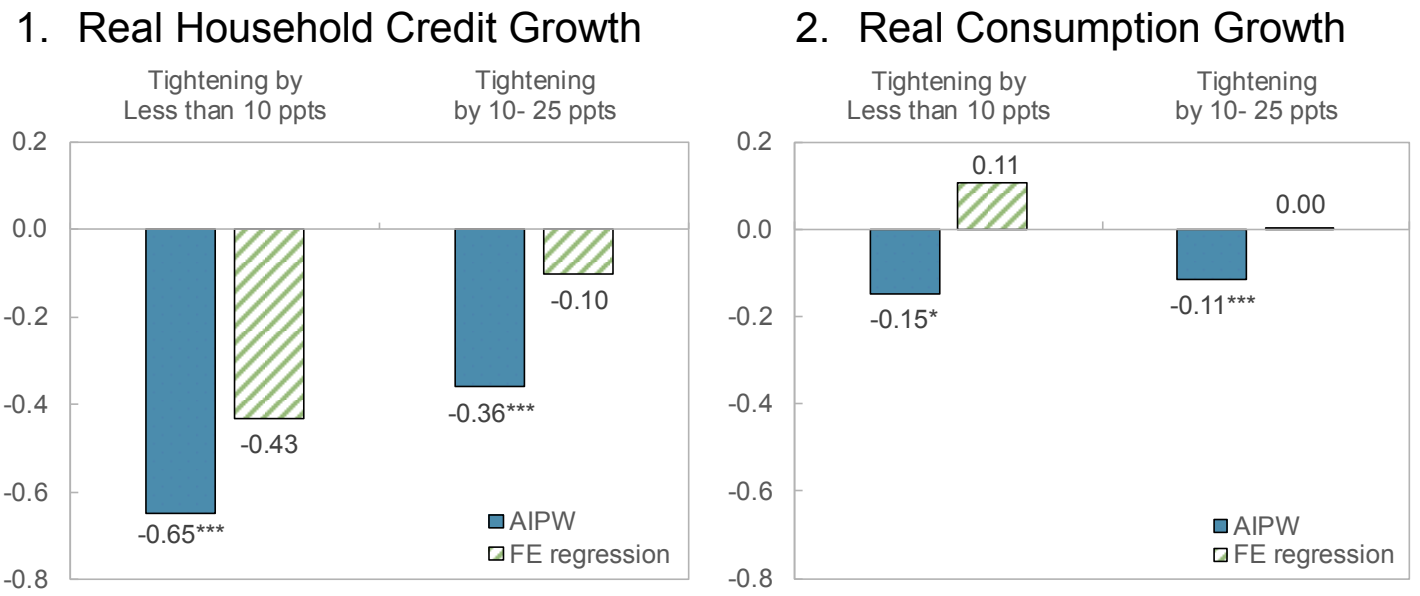

Sources: The iMaPP database, Bloomberg, BIS, OECD, others (see Appendix IV), and the authors' estimation. Notes: The figure reports the cumulative effects of a one-ppt LTV tightening after four quarters, obtained by the augmented inverse propensity-score weighted ("AIPW") estimation and the fixed effects estimation with the timing assumption ("FE regression"), which are explained in detail in Appendices VI and VII, respectively. The FE regression uses the interaction terms of $\Delta L T V$ with the dummy variables for each bucket (i.e., a tightening by less than 10 ppts and a tightening by more than or equal to $10 \mathrm{ppts}$ and less than $25 \mathrm{ppts}$ ). To mitigate the influence of outliers, observations with $\Delta \mathrm{LTV}$ less than or equal to -25 ppts are excluded for the estimation. Confidence levels: ${ }^{* * *} p<0.01,{ }^{* *} p<0.05,{ }^{*} p<0.1$. Standard errors are clustered by country.

The fixed effect (FE) estimation based on the timing assumption also finds nonlinear effects on household credit, but the estimates are not significant and are smaller than the AIPW estimates (Panel 1 of Figure 6). ${ }^{25}$ This result supports the idea that the typical regression estimates based on the timing assumption suffer from an attenuation bias (Appendix III) and that the AIPW better addresses the endogeneity issue.

The estimated side effects are found to be smaller and less robust. The AIPW estimates of the consumption growth decline are around 0.1 ppts, and without a clear nonlinear pattern (Panel 2 of Figure 6). Taking this together with the nonlinear effects on credit, a tightening by less than 10 ppts appears to be more efficient in the sense that it has larger effects on

\footnotetext{
${ }^{25}$ Jácome and Mitra (2015) also use the timing assumption and report an effect on mortgage credit of 0.07 ppts in four quarters, based on data of five economies.
} 
credit but smaller side effects on consumption, although a formal welfare analysis is beyond the scope of this paper.

\section{Do Initial LTV Levels Matter?}

It is conceivable that a given change in the LTV limits could have differential impacts on macro-financial outcomes depending on whether the starting level of the LTV ratio cap is still relatively loose, or already tight. To examine this hypothesis, we estimate the effects conditioning on the level of LTV limits. The threshold levels sorting loose and tight initial levels are set to 100 percent in AEs and 90 percent in EMs, which corresponds to the median LTV level for each of these two groups. ${ }^{26}$ We then define the LTV limits to be "tight" for all observations below these thresholds (i.e. for low permissible LTV). Using different cut-off levels yields broadly similar results. We use the panel regression with the timing assumption for the results distinguishing AEs and EMDEs, while we also conduct the AIPW estimation as a robustness check without distinguishing AEs and EMDEs.

The results suggest that the initial LTV level matters, especially for household consumption, with the effect of an additional tightening on consumption larger when LTV limits are already tight. In general, a tightening of the LTV limits by one percentage point is only significantly associated with a decline in consumption if the LTV is already tight, and this result is consistent across subsamples (Panel 2 of Figure 7).

In contrast, the effects on household credit growth of a tightening of LTV limits are generally more pronounced when starting from a loose level, such as when the LTV measures are first introduced. The effects on household credit in AEs are only significant when the initial level of the LTV cap is loose (above or equal to 100 percent). In EMDEs, the effects of tightening LTV limits are also slightly stronger when the initial LTV levels are high, even if the difference is not always statistically significant, (Panel 1 of Figure 7).

These insights are corroborated when using the AIPW method. Excluding the observations with initial LTV levels higher or equal to 100 percent, the estimated effect on household credit becomes smaller but the side effect on consumption increases compared with the full sample results (Appendix VI Table 1).

Differential effects on credit (stronger when the initial level of the LTV cap is loose) and on consumption (stronger when initial level of the LTV cap is tight), can conceivably be reconciled by noting that when the starting point is a loose initial level, and when borrowers then face a tightening of the permissible LTV ratio, many borrowers will adjust to this change by reducing the size of the loan and meeting the higher required downpayment out of

\footnotetext{
${ }^{26}$ The thresholds of "tight" LTV limit are based on the distribution of the LTV levels in our sample, for AEs and EMs separately, to account for distributional differences. These thresholds represent the median LTV for each sample group.
} 
existing own funds. While this implies a drop in credit, the typical borrower will still go ahead with the home purchase, and the drop in consumption may not be pronounced. Conversely, when the initial LTV is already tight and it is further tightened, more borrowers are in a situation where they had already reduced credit (i.e., did not buy the house) and now do not reduce borrowing further, but rather increase savings to attain the new LTV limit. Thus, the decline in consumption is more substantial in this case.

Judging from the results for both household credit and consumption, we conclude that there is a tradeoff in tightening LTV limits, with the tightening of this measure having relatively more substantial side effects on consumption when initial LTV limits are already tight. This suggests that countries with tight LTV limits might be better off considering other macroprudential tools to complement the existing portfolio of tools, which is in line with international best practices (IMF-FSB-BIS, 2016).

\section{Figure 7. The Effects of One Percentage Point Tightening in LTV Limits on Household Credit and Private Consumption Growth}

1. Real Household Credit Growth

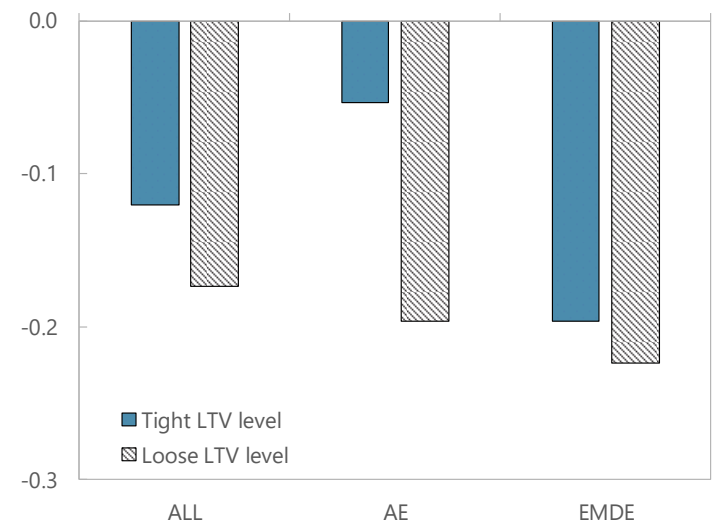

2. Real Consumption Growth

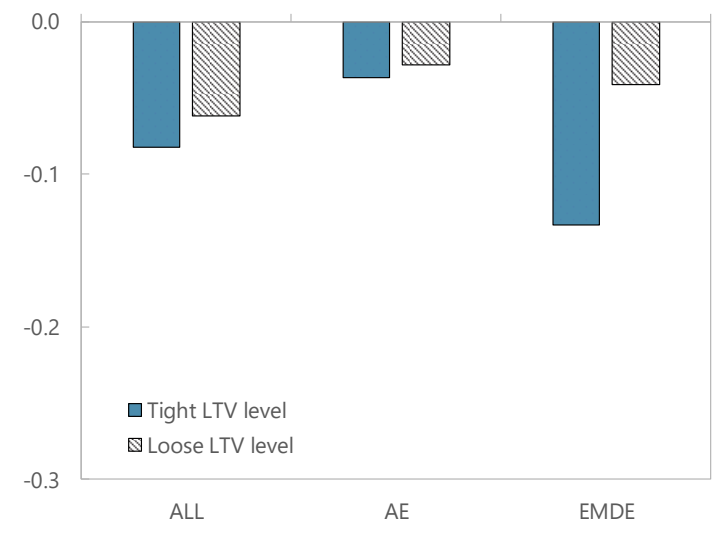

Sources: The iMaPP database, Bloomberg, BIS, OECD, others (see Appendix IV), and the authors' estimation. Note: The figure shows the cumulative effects of one-ppt LTV tightening after four quarters, conditioning on the initial LTV level, estimated by the fixed effects estimation with the timing assumption. Specifically, the bars show the cumulative sum of the $\Delta \mathrm{LTV}$ coefficients in the previous four quarters is presented for each country group. The "high LTV level" in AEs and EMDEs refers to the LTV limits greater or equal to 100 percent and 90 percent, respectively (i.e., looser limits), and the "low LTV level" refers those levels below the aforementioned thresholds (i.e., tighter limits). For more details see Appendix VIII Table 15.

\section{Conclusions}

In this paper, we presented a new comprehensive database of macroprudential policies (iMaPP) that combines information from various sources. Exploiting the unique features of this database and using a method that aims to better address endogeneity problems, we found strong and nonlinear effects on household credit of LTV changes. The effects per one percentage point (ppt) LTV tightening are diminishing with the size of the LTV adjustment, likely due to policy leakage effects. The largest per-unit impact is found for the most popular action in our sample - a tightening of less than $10 \mathrm{ppts}$ - and it indicates that a one ppt LTV tightening cumulatively reduces household credit growth by up to 0.65 ppts after one year. 
This result highlights the importance of considering nonlinearity in estimating policy effects, as well as reverse causality.

We also made progress toward assessing side effects of macroprudential policies, by investigating their impact on private consumption. These effects are statistically significant, but more moderate in size relative to effects on household credit. We also establish a nonlinearity in the effects of tightening of LTV limits on consumption, with the effect of an additional tightening larger when LTV limits are already tight.

The new iMaPP database will be updated annually with data from the IMF's new Annual Survey on Macroprudential Policies, offering many opportunities for further research. Among the issues that deserve further exploration are the quantification of the effects of other macroprudential policies and the cost-benefit analysis of macroprudential policies. ${ }^{27}$

${ }^{27}$ See Brandao and others (forthcoming) for further progress in this regard. 


\section{APPENDIX I. THE IMAPP DATABASE}

We construct the iMaPP database integrating information from major existing databases and national sources. The integrated databases are Lim and others $(2011,2013)$, the Global Macroprudential Policy Instrument (GMPI) survey conducted by the IMF in 2013, Shim and others (2013), the database by European Systemic Risk Board (ESRB), and the IMF's Annual Macroprudential Policy Survey (IMF survey). We also obtain information from national sources; the Bank for International Settlements (BIS), the Financial Stability Board (FSB), and the IMF official documents. Appendix I Figure 1 visualizes how each source contributes to the iMaPP database. Going forward, the iMaPP database will be annually updated with the IMF's Annual Macroprudential Policy Survey.

Data availability differs across time and countries, largely reflecting reporting differences. The number of observations improves over time, particularly after 2000 (Section II.D.). Also, there are relatively more observations for 65 countries (listed in Appendix I Table 1), whose information comes from several sources. Appendix I Table 2 lists the 66 economies where the average LTV limit is available.

Appendix I Table 3 lists all the categories of macroprudential instruments available in the iMaPP database, and their definitions.

\section{Appendix I Figure 1. Sources and Coverages of the iMaPP Database}

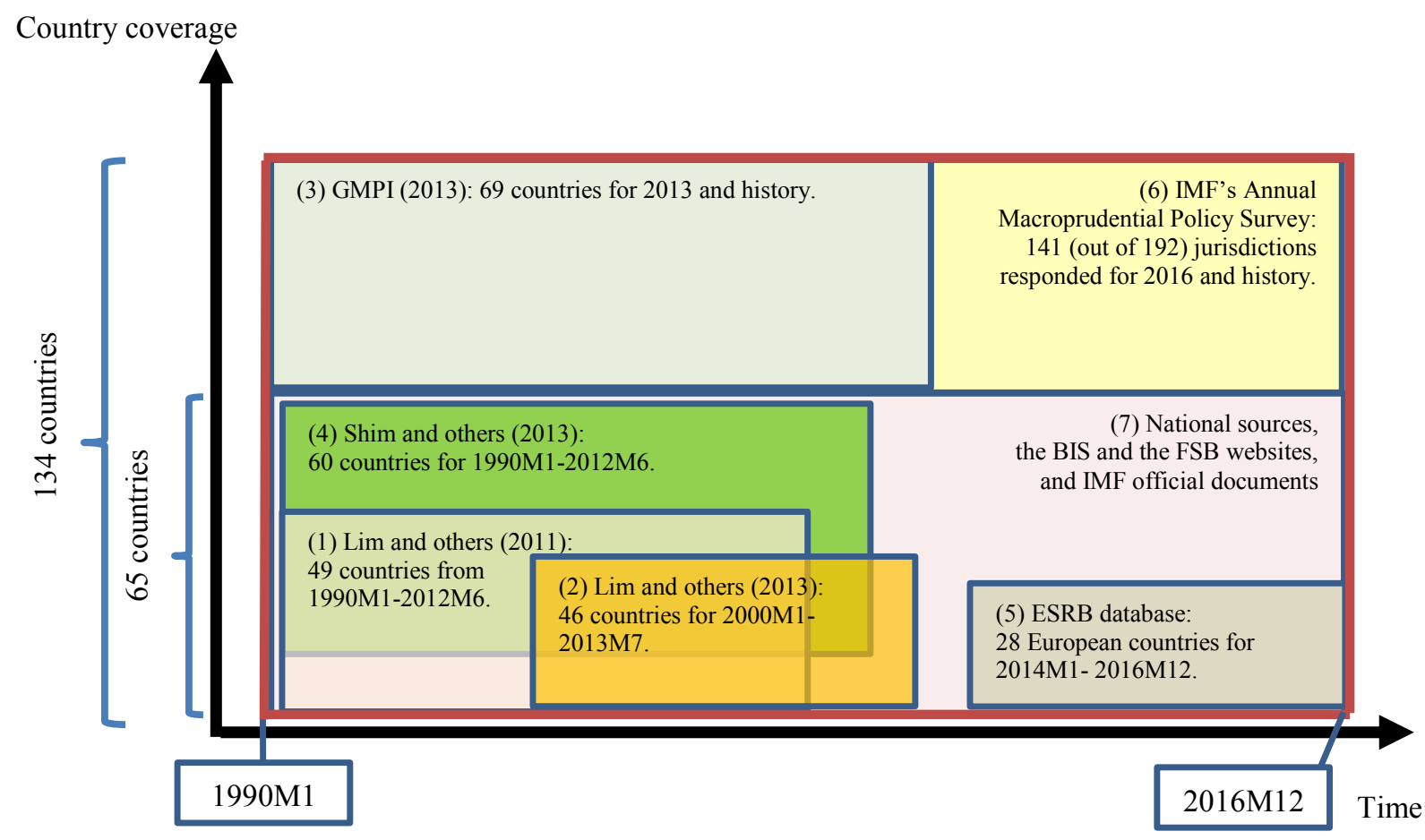

Source: Authors. 
Appendix I Table 4 shows how the iMaPP database compares with other existing databases of macroprudential policy. First, it shows that the iMaPP database has a wider coverage of instruments, countries, and sample periods. Second, it shows that the iMaPP database provides the average LTV limit as well as traditional dummy-type policy action indices, while most existing databases provide dummy-type indices only. Exceptions are Vandenbussche and others (2015) and Richter and others (2018), who provides intensityadjusted policy indices.

\title{
Appendix I Table 1. Countries Covered in the iMaPP Database
}

\author{
Advanced economies (AEs; 36) \\ Australia, Austria, Belgium, Canada, Cyprus, Czech Republic, Denmark, Estonia, Finland, \\ France, Germany, Greece, Hong Kong SAR, Iceland, Ireland, Israel, Italy, Japan, Korea, \\ Latvia, Lithuania, Luxembourg, Malta, Netherlands, New Zealand, Norway, Portugal, \\ Singapore, Slovak Republic, Slovenia, Spain, Sweden, Switzerland, Taiwan Province of \\ China, United Kingdom, United States. \\ Emerging market and developing economies (EMDEs; 98) ${ }^{2}$ \\ Albania, Algeria, Angola, Argentina, Armenia, Azerbaijan, The Bahamas, Bahrain, Bangladesh, \\ Belarus, Benin, Bhutan, Bosnia and Herzegovina, Botswana, Brazil, Brunei Darussalam, Bulgaria, \\ Burkina Faso, Burundi, Cambodia, Cabo Verde, Chile, China, Colombia, Congo Democratic \\ Republic, Costa Rica, Croatia, Cote d'Ivoire, Dominican Republic, Ecuador, El Salvador, Ethiopia, \\ Fiji, Gabon, Gambia, Georgia, Ghana, Guinea Bissau, Haiti, Honduras, Hungary, India, \\ Indonesia, Jamaica, Jordan, Kazakhstan, Kenya, Kosovo, Kyrgyz Republic, Kuwait, Lebanon, \\ Laos, Lesotho, Macedonia, Malaysia, Mali, Mauritania, Mauritius, Mexico, Moldova, Mongolia, \\ Montenegro, Morocco, Mozambique, Nepal, Niger, Nigeria, Oman, Pakistan, Paraguay, Peru, \\ Philippines, Poland, Qatar, Romania, Russia, Samoa, Saudi Arabia, Serbia, South Africa, Sri \\ Lanka, St. Kitts and Nevis, Senegal, Solomon Islands, Sudan, Tajikistan, Tanzania, Timor Leste, \\ Thailand, Togo, Tonga, Trinidad and Tobago, Tunisia, Turkey, Uganda, Ukraine, United Arab \\ Emirates, Uruguay, Vanuatu, Venezuela, Vietnam, Yemen, and Zambia. \\ Source: World Economic Outlook (IMF, 2018b). \\ Notes: The 65 economies with relatively more observations are listed in bold letters. They are 35 AEs and 30 EMDEs.
}

\section{Appendix I Table 2. Countries with the Average LTV Limit in the iMaPP Database}

\section{Economies with the average LTV limit (66 economies)}

Argentina, Australia, Austria, Belgium, Brazil, Bulgaria, Canada, Chile, China, Colombia, Croatia, Cyprus, Czech Republic, Denmark, Estonia, Finland, France, Germany, Greece, Hong Kong SAR. Hungary, Iceland, India, Indonesia, Ireland, Israel, Italy, Japan, Korea, Kuwait, Latvia, Lebanon, Lithuania, Luxembourg, Malaysia, Malta, Mexico, Mongolia, Netherlands, New Zealand, Nigeria, Norway, Peru, Philippines, Poland, Portugal, Romania, Russia, Saudi Arabia, Serbia, Singapore, Slovak Republic, Slovenia, South Africa, Spain, Sweden, Switzerland, Taiwan Province of China, Thailand, Turkey, Ukraine, United Arab Emirates, United Kingdom, United States, Uruguay, and Vietnam.

Source: Authors. 


\section{Appendix I Table 3. Definitions of Macroprudential Policy Instruments}

\begin{tabular}{|c|c|}
\hline & Definition \\
\hline $\begin{array}{l}1 \text { Countercyclical } \\
\text { Buffers (CCB) }\end{array}$ & $\begin{array}{l}\text { A requirement for banks to maintain a countercyclical capital buffer. Implementations at } 0 \% \text { are not } \\
\text { considered as a tightening in dummy-type indicators. }\end{array}$ \\
\hline 2 Conservation & $\begin{array}{l}\text { Requirements for banks to maintain a capital conservation buffer, including the one established under } \\
\text { Basel III. }\end{array}$ \\
\hline $\begin{array}{l}3 \text { Capital } \\
\text { Requirements* }\end{array}$ & $\begin{array}{l}\text { Capital requirements for banks, which include risk weights, systemic risk buffers, and minimum capital } \\
\text { requirements. Countercyclical capital buffers and capital conservation buffers are captured in their } \\
\text { sheets respectively and thus not included here. Subcategories of capital measures are also provided, } \\
\text { classifying them into household sector targeted }(\mathrm{HH}) \text {, corporate sector targeted (Corp), broad-based } \\
\text { (Gen), and FX-loan targeted ( } \mathrm{FX} \text { ) measures. }\end{array}$ \\
\hline $\begin{array}{l}4 \text { Leverage Limits } \\
\text { (LVR) }\end{array}$ & $\begin{array}{l}\text { A limit on leverage of banks, calculated by dividing a measure of capital by the bank's non-risk- } \\
\text { weighted exposures (e.g., Basel III leverage ratio). }\end{array}$ \\
\hline $\begin{array}{l}5 \text { Loan Loss } \\
\text { Provisions (LLP) }\end{array}$ & $\begin{array}{l}\text { Loan loss provision requirements for macroprudential purposes, which include dynamic provisioning } \\
\text { and sectoral provisions (e.g. housing loans). }\end{array}$ \\
\hline $\begin{array}{l}6 \text { Limits on Credit } \\
\text { Growth (LCG)* }\end{array}$ & $\begin{array}{l}\text { Limits on growth or the volume of aggregate credit, the household-sector credit, or the corporate-sector } \\
\text { credit by banks, and penalties for high credit growth. Subcategories of limits to credit growth are also } \\
\text { provided, classifying them into household sector targeted }(\mathrm{HH}) \text {, corporate sector targeted (Corp), and } \\
\text { broad-based (Gen) measures. }\end{array}$ \\
\hline $\begin{array}{l}7 \text { Loan } \\
\text { Restrictions } \\
\text { (LoanR)* }\end{array}$ & $\begin{array}{l}\text { Loan restrictions, that are more tailored than those captured in "LCG". They include loan limits and } \\
\text { prohibitions, which may be conditioned on loan characteristics (e.g., the maturity, the size, the LTV ratio } \\
\text { and the type of interest rate of loans), bank characteristics (e.g., mortgage banks), and other factors. } \\
\text { Subcategories of loan restrictions are also provided, classifying them into household sector targeted } \\
(\mathrm{HH}) \text {, and corporate sector targeted (Corp) measures. Restrictions on foreign currency lending are } \\
\text { captured in "LFC". }\end{array}$ \\
\hline $\begin{array}{l}8 \text { Limits on } \\
\text { Foreign } \\
\text { Currency (LFC) }\end{array}$ & Limits on foreign currency (FC) lending, and rules or recommendations on FC loans. \\
\hline $\begin{array}{l}9 \text { Limits on the } \\
\text { Loan-to-Value } \\
\text { Ratio (LTV) } \\
\end{array}$ & $\begin{array}{l}\text { Limits to the loan-to-value ratios, including those mostly targeted at housing loans, but also includes } \\
\text { those targeted at automobile loans, and commercial real estate loans. }\end{array}$ \\
\hline $\begin{array}{l}10 \text { Limits on the } \\
\text { Debt-Service-to- } \\
\text { Income Ratio } \\
\text { (DSTI) }\end{array}$ & $\begin{array}{l}\text { Limits to the debt-service-to-income ratio and the loan-to-income ratio, which restrict the size of debt } \\
\text { services or debt relative to income. They include those targeted at housing loans, consumer loans, and } \\
\text { commercial real estate loans. }\end{array}$ \\
\hline 11 Tax Measures & $\begin{array}{l}\text { Taxes and levies applied to specified transactions, assets, or liabilities, which include stamp duties, and } \\
\text { capital gain taxes. }\end{array}$ \\
\hline $\begin{array}{l}12 \text { Liquidity } \\
\text { Requirements }\end{array}$ & $\begin{array}{l}\text { Measures taken to mitigate systemic liquidity and funding risks, including minimum requirements for } \\
\text { liquidity coverage ratios, liquid asset ratios, net stable funding ratios, core funding ratios and external } \\
\text { debt restrictions that do not distinguish currencies. }\end{array}$ \\
\hline $\begin{array}{l}13 \text { Limits on the } \\
\text { Loan-to-Deposit } \\
\text { Ratio (LTD) }\end{array}$ & Limits to the loan-to-deposit (LTD) ratio and penalties for high LTD ratios. \\
\hline $\begin{array}{l}14 \text { Limits on } \\
\text { Foreign } \\
\text { Exchange } \\
\text { Positions (LFX) }\end{array}$ & $\begin{array}{l}\text { Limits on net or gross open foreign exchange (FX) positions, limits on FX exposures and FX funding, } \\
\text { and currency mismatch regulations. }\end{array}$ \\
\hline $\begin{array}{l}15 \text { Reserve } \\
\text { Requirements } \\
(\mathrm{RR})^{\star}\end{array}$ & $\begin{array}{l}\text { Reserve requirements (domestic or foreign currency) for macroprudential purposes. Please note that } \\
\text { this category may currently include those for monetary policy as distinguishing those for } \\
\text { macroprudential or monetary policy purposes is often not clear-cut. A subcategory of reserve } \\
\text { requirements is provided for those differentiated by currency (FCD), as they are typically used for } \\
\text { macroprudential purposes. }\end{array}$ \\
\hline 16 SIFI & $\begin{array}{l}\text { Measures taken to mitigate risks from global and domestic systemically important financial institutions } \\
\text { (SIFIs), which includes capital and liquidity surcharges. }\end{array}$ \\
\hline 17 Other & $\begin{array}{l}\text { Macroprudential measures not captured in the above categories-e.g., stress testing, restrictions on } \\
\text { profit distribution, and structural measures (e.g., limits on exposures between financial institutions). }\end{array}$ \\
\hline
\end{tabular}

Source: Authors.

Note: ${ }^{*}$ indicates that subcategories are available. 


\section{Appendix I Table 4. The iMaPP Database and Other Existing Databases}

\begin{tabular}{|c|c|c|c|c|c|c|c|}
\hline & Sources & $\begin{array}{l}\text { Sample } \\
\text { Period }\end{array}$ & $\begin{array}{l}\text { Country } \\
\text { Coverage }\end{array}$ & $\begin{array}{l}\text { Instru- } \\
\text { ments }{ }^{1 /}\end{array}$ & $\begin{array}{l}\text { Frequ- } \\
\text { ency }\end{array}$ & $\begin{array}{l}\text { Text } \\
\text { Info }\end{array}$ & MaPP Indexes ${ }^{2 /}$ \\
\hline The iMaPP database & $\begin{array}{l}\text { Databases 1-6 below, national sources, } \\
\text { IMF official documents, and websites of } \\
\text { the BIS and the FSB. }\end{array}$ & $\begin{array}{l}\text { 1990M1- } \\
\text { 2016M12 }\end{array}$ & 138 & 27 & M & Yes & $\begin{array}{l}\text { - Average LTV limit } \\
\text { - T/L indexes } \\
\text { by instrument }\end{array}$ \\
\hline \multicolumn{8}{|c|}{ Databases Integrated in the iMaPP Database } \\
\hline 1 Lim et al. (2011) & $\begin{array}{l}\text { IMF Financial Stability and } \\
\text { Macroprudential Policy Survey, } 2010\end{array}$ & $\begin{array}{l}1990- \\
2011\end{array}$ & 49 & 10 & $\begin{array}{c}\text { As } \\
\text { reported }\end{array}$ & Yes & - \\
\hline 2 Lim et al. (2013) & National sources & $\begin{array}{l}2000 \mathrm{M} 1- \\
2013 \mathrm{M} 7\end{array}$ & 39 & 12 & M & Yes & $\begin{array}{l}\text { - Institutional } \\
\text { arrangement indexes }\end{array}$ \\
\hline $\begin{array}{l}3 \text { Global Macroprudential } \\
\text { Policy Instrument (GMPI, } \\
\text { 2013) }\end{array}$ & IMF survey to authorities & $\begin{array}{c}2013 \text { and } \\
\text { history }\end{array}$ & 133 & 17 & $\begin{array}{l}\text { As } \\
\text { reported }\end{array}$ & Yes & - \\
\hline 4 Shim et al. (2013) & $\begin{array}{l}\text { National sources, and data from } \\
\text { published papers when they are verified } \\
\text { at national sources. }\end{array}$ & $\begin{array}{l}\text { 1990M1 - } \\
2012 \mathrm{M} 6\end{array}$ & 60 & 8 & M & Yes & $\begin{array}{l}\text { - T/L indexes } \\
\text { by instrument }\end{array}$ \\
\hline 5 ESRB database & Country authorities & $\begin{array}{c}\text { 2013M1- } \\
\text { latest }\end{array}$ & $\begin{array}{c}28 \\
\text { (Europe) }\end{array}$ & 18 & M & Yes & - \\
\hline $\begin{array}{l}6 \text { IMF's Annual } \\
\text { Macroprudential Policy } \\
\text { Survey }\end{array}$ & Country authorities & $\begin{array}{l}2016 \text { and } \\
\text { some } \\
\text { history }\end{array}$ & 141 & 69 & $\begin{array}{l}\text { As } \\
\text { reported }\end{array}$ & Yes & - \\
\hline \multicolumn{8}{|l|}{ Other Databases } \\
\hline $\begin{array}{l}7 \text { Crowe, Dell'Ariccia, Igan, } \\
\text { and Rabanal (2013) }\end{array}$ & $\begin{array}{l}\text { The IMF survey of central bankers and } \\
\text { bank regulators. }\end{array}$ & $\begin{array}{l}2010 \text { and } \\
\text { history }\end{array}$ & 36 & 3 & A & Yes & - \\
\hline $\begin{array}{l}8 \text { Vandenbussche et al } \\
\text { (2015) }\end{array}$ & $\begin{array}{l}\text { National sources, IMF papers, and } \\
\text { academic papers }\end{array}$ & $\begin{array}{l}\text { late '90 - } \\
2010\end{array}$ & $\begin{array}{c}16 \\
\text { (Europe) }\end{array}$ & 29 & Q & Yes & $\begin{array}{l}\text { - Intensity-adjusted } \\
\mathrm{T} / \mathrm{L} \text { indexes } \\
\text { by instrument }\end{array}$ \\
\hline $\begin{array}{l}9 \text { Dimova, Kongsamut, and } \\
\text { Vandenbussche (2016) }\end{array}$ & $\begin{array}{l}\text { Vandenbussche et al. (2015) and } \\
\text { national sources. }\end{array}$ & $\begin{array}{l}\text { 2002Q1- } \\
\text { 2012Q4 }\end{array}$ & $\begin{array}{c}4 \\
\text { (Europe) }\end{array}$ & 6 & Q & Yes & - \\
\hline 10 Kuttner and Shim (2016) & $\begin{array}{l}\text { Extended Shim et al. (2013) for 1980M1- } \\
\text { 1989M12 and added housing taxes and } \\
\text { subsidies }\end{array}$ & 1980Q1- & 60 & 9 & M & Yes & $\begin{array}{l}\text { - T/L indexes by } \\
\text { by instrument }\end{array}$ \\
\hline 11 Zhang and Zoli (2016) & Lim et al. (2013), and national sources & $\begin{array}{l}\text { 2000Q1- } \\
\text { 2013Q4 }\end{array}$ & 46 & - & Q & No & - Aggregate $T / L$ index \\
\hline $\begin{array}{l}12 \text { Bruno, Shim, and Shin } \\
\text { (2017) }\end{array}$ & Shim et al. (2013) and national sources & $\begin{array}{l}\text { 2004Q1- } \\
\text { 2013Q4 }\end{array}$ & 12 & - & Q & No & - Aggregate $T / L$ indexes \\
\hline 13 Cerutti et al. (2017a) & $\begin{array}{l}\text { The GMPI and official documents, cross- } \\
\text { checking with Kuttner and Shim (2016), } \\
\text { Crowe et al. (2011), and other surveys }\end{array}$ & $\begin{array}{r}2000- \\
2013\end{array}$ & 119 & 12 & A & No & $\begin{array}{l}\text { - Number of } \\
\text { instruments in place } \\
\text { - Indicator of the } \\
\text { use by instr. }\end{array}$ \\
\hline 14 Cerutti et al. (2017b) & The GMPI and national sources & $\begin{array}{l}\text { 2000Q1- } \\
2014 Q 4\end{array}$ & 64 & 9 & Q & Yes & $\begin{array}{l}-\mathrm{T} / \mathrm{L} \text { indexes by } \\
\text { by instrument }\end{array}$ \\
\hline $\begin{array}{l}15 \text { Akinci and Olmstead- } \\
\text { Rumsey (2018) }\end{array}$ & $\begin{array}{l}\text { Lim et al. (2011), supplemented with } \\
\text { Shim et al. (2013), national sources, the } \\
\text { GMPI (2013), and Ceruttie et al. } \\
(2017 a, b)\end{array}$ & $\begin{array}{l}\text { 2000Q1- } \\
2013 Q 4\end{array}$ & 57 & 7 & Q & No & $\begin{array}{l}-\mathrm{T} / \mathrm{L} \text { indexes } \\
\text { by instrument }\end{array}$ \\
\hline 16 Budnik and Kleibl (2018) & Country authorities & $\begin{array}{l}1995- \\
2014\end{array}$ & $\begin{array}{l}28 \mathrm{EU} \\
\text { member } \\
\text { states }\end{array}$ & 64 & M & Yes & $\begin{array}{l}\text { - NA, while } \\
\text { tightening/loosening tags } \\
\text { are available }\end{array}$ \\
\hline $\begin{array}{l}17 \text { Richter, Schularick, and } \\
\text { Shim (2018) }\end{array}$ & $\begin{array}{l}\text { Extended Shim et al. (2013), adding an } \\
\text { intensity-adjusted LTV index }\end{array}$ & $\begin{array}{l}\text { 1990Q1- } \\
\text { 2012Q2 }\end{array}$ & 56 & 7 & $Q$ & Yes & $\begin{array}{l}\text { - Intensity-adjusted } \\
\text { LTV change index } \\
\text { - T/L indexes } \\
\text { by instrument }\end{array}$ \\
\hline
\end{tabular}

Source: Authors.

Notes: 1/ The classification of instruments differs across databases. The column "Instruments" shows the number of categories, including subcategories, available in each dataset, without standardizing classification.

2/ "T/L indexes" is the dummy-type indexes for tightening and loosening actions of macroprudential policy measures. 


\section{Appendix II. Constructing the AVerage LTV Limit}

Constructing average LTV limits requires a few adjustments. First, when a country introduces a LTV limit on a new category of loans, for the periods prior to the introduction, we set the value at 100 for the category. This treatment is necessary for the average LTV limit to correctly suggest a tightening when an LTV limit is introduced for an additional loan category, as illustrated in Appendix II Table 1. When the introduced regulatory limits on LTV ratios are above 100 percent (e.g., as in Netherlands and Slovakia), we set the value at 110 for the periods prior to the introduction. ${ }^{28}$ Second, when a country does not have any LTV limits, we set the value at 100, to be consistent with the logic of the first treatment.

The average LTV limit series summarizes reasonably well regulatory developments even when there are multiple LTV limits in a country. For example, if we alternatively choose the tightest limit, instead of the simple average, there would be a risk to miss regulatory changes in another important loan category if the regulatory LTV limits in that category were not the tightest. By contrast, the simple average of regulatory LTV limits reflects changes in all categories. And empirically, its evolution exhibits a picture consistent with the dummy-type index for the developments of LTV limits.

Please note that the average LTV limit, as well as dummy-type policy action indicators, are recorded based on their effective dates, because the announcement dates are often not available. The text information in the iMaPP database contains the announcement dates when they are available.

\section{Appendix II Table 1. An Illustration on the Construction of the Average LTV Limit}

\begin{tabular}{rrrrrrrrr}
\hline & \multicolumn{2}{c}{ 1. Without the Treatment } & & \multicolumn{3}{c}{ 2. With the Treatment } \\
\cline { 2 - 3 } \cline { 6 - 8 } & $\begin{array}{c}\text { Mortgages } \\
\text { for Luxury } \\
\text { Houses }\end{array}$ & $\begin{array}{c}\text { Mortgages } \\
\text { for Other } \\
\text { Houses }\end{array}$ & $\begin{array}{c}\text { Average } \\
\text { LTV Limit }\end{array}$ & & $\begin{array}{c}\text { Mortgages } \\
\text { for Luxury } \\
\text { Houses }\end{array}$ & $\begin{array}{c}\text { Mortgages } \\
\text { for Other } \\
\text { Houses }\end{array}$ & $\begin{array}{c}\text { Average } \\
\text { LTV Limit }\end{array}$ \\
\hline Nov-99 & 70 & 70 & 70 & 100 & 85 \\
Dec-99 & 70 & & 70 & 70 & 100 & 85 \\
Jan-00 & 70 & 80 & 75 & 70 & 80 & 75 \\
Feb-00 & 70 & 80 & 75 & 70 & 80 & 75 \\
\hline
\end{tabular}

Source: Authors.

Notes: In this illustration, without any treatment, the average LTV limit mistakenly appears as a loosening when the LTV limit on "mortgages for other houses" is introduced in January 2000, although it should be a tightening. With the treatment to set the value at 100 (in red) for the periods prior to the introduction, the average LTV limit correctly indicates the event as a tightening.

\footnotetext{
${ }^{28} 110$ percent is an ad-hoc value, although average LTV ratio of all existing mortgage loans in Netherlands were about 110 percent when the LTV limits were introduced.
} 


\section{ApPendix III. Attenuation Bias in a Standard Regression Analysis}

To identify the causal effects of macroprudential policy (MaPP), previous studies typically use the timing assumption of no contemporaneous policy effects. That is, macroprudential policy does not affect macro-financial variables (e.g., credit growth) within the same quarter. This appendix shows when the approach is valid and when it fails and thus suffers from the attenuation bias.

Consider a structural form vector autoregression (VAR) with one lag (without the constant term or other controls for simplicity):

$$
\begin{gathered}
\left(\begin{array}{cc}
1 & -\beta \\
-\gamma & 1
\end{array}\right)\left(\begin{array}{c}
C_{t} \\
M P_{t}
\end{array}\right)=\left(\begin{array}{ll}
\alpha_{11} & \alpha_{12} \\
\alpha_{21} & \alpha_{22}
\end{array}\right)\left(\begin{array}{c}
C_{t-1} \\
M P_{t-1}
\end{array}\right)+\left(\begin{array}{c}
\varepsilon_{t} \\
\eta_{t}
\end{array}\right), \\
\left(\begin{array}{c}
\varepsilon_{t} \\
\eta_{t}
\end{array}\right) \sim \text { i.i.d. }\left(\left(\begin{array}{l}
0 \\
0
\end{array}\right),\left(\begin{array}{cc}
\sigma_{\varepsilon}^{2} & 0 \\
0 & \sigma_{\eta}^{2}
\end{array}\right)\right),
\end{gathered}
$$

where $C_{t}$ is credit and $M P_{t}$ is a MaPP measure, with $\beta \leq 0$ (credit reduces when MaPP tightens) and $\gamma \geq 0$ (MaPP tightens when credit increases). Then the reduced form VAR is:

$$
\left(\begin{array}{c}
C_{t} \\
M P_{t}
\end{array}\right)=\frac{1}{1-\beta \gamma}\left(\begin{array}{cc}
\alpha_{11}+\beta \alpha_{21} & \alpha_{12}+\beta \alpha_{22} \\
\gamma \alpha_{11}+\alpha_{21} & \gamma \alpha_{12}+\alpha_{22}
\end{array}\right)\left(\begin{array}{c}
C_{t-1} \\
M P_{t-1}
\end{array}\right)+\frac{1}{1-\beta \gamma}\left(\begin{array}{ccc}
\varepsilon_{t}+\beta \eta_{t} \\
\gamma \varepsilon_{t}+ & \eta_{t}
\end{array}\right) .
$$

Regressing $C_{t}$ on $\left(C_{t-1}, M P_{t-1}\right)$ provides the estimated coefficient on $M P_{t-1}$, which will converge to:

$$
\frac{\alpha_{12}+\beta \alpha_{22}}{1-\beta \gamma}
$$

where $\alpha_{12}$ captures the direct impact from $M P_{t-1}$ to $C_{t}$ and $\beta \alpha_{22}$ captures the indirect impact through $M P_{t}$, while the denominator $1-\beta \gamma$ shrinks the total impact. Thus, if $\beta \neq 0$ and $\gamma \neq$ 0 (i.e., $\beta \gamma \leq 0$ ), this lag approach ends up with an attenuation bias towards zero on the impact. This bias is severer if the contemporaneous policy effect $(\beta)$ is stronger (e.g., faster transmission, or if the reverse causality effect $(\gamma)$ is stronger (e.g., quicker policy formulation upon developments).

If $\beta=0$ (i.e., no contemporaneous policy effect), then the OLS coefficient on $M P_{t-1}$ would be the total impact of $M P_{t-1}$ on $C_{t}$. That is, the lag approach is valid when there is no contemporaneous policy effect, which is the timing assumption commonly assumed in the literature. If there is no reverse causality (i.e., $\gamma=0$ ) to begin with, then the approach is of course valid, too.

The attenuation-bias argument will still hold, even if the left-hand-side variables are $\left(C_{t+1}, M P_{t+1}\right)$, in the spirit of the local projection. The interpretation of $\alpha_{12}$ is only changed to the impact from $M P_{t-1}$ to $C_{t+1}$, instead of $C_{t}$.

The results hold for a more general setting with the constant term and any other control variables included in the regressors, because of the Frisch-Waugh-Lovell theorem. 


\section{Appendix IV. Data for the Panel Regression Analysis With DUMmy-Type INDICATORS}

Appendix IV Table 1 provides the definitions and sources of the variables used in regression analysis in Sections III and IV. Appendix IV Table 2 provides the list of sample economies used in panel regression analysis in Section III. Appendix IV Table 3 provides the summary statistics of the variables used in estimation.

MaPP variables used in Section III are the average of the net number of policy tightening over the current and past three quarters to account for potentially delayed effects. They are constructed for individual instruments and for groups of instruments. "Loan-targeted" group consists of the "Demand" and the "Supply-loans" instruments. "Demand" instruments are the limits to the loan-to-value ratio (LTV) and the limits to the debt-service-to-income (DSTI) ratio. "Supply-loans" measures are limits to credit growth (LCG), loan loss provisions (LLP), loan restrictions (LoanR), limits to the loan to deposit ratio, and limits to foreign currency loans. "Supply-general" instruments are reserve requirements, liquidity requirements, and limits to FX positions. "Supply-capital" instruments are leverage limits (LVR), countercyclical buffers (CCB), conservation buffers, and capital requirements. "MaPP index" is the sum of the dummies for all of 17 categories (see also Appendix I Table 3).

The distinction between demand-side and supply-side tools is whether the tool is on the borrowers (i.e., credit demand) or on the financial institutions (i.e., credit supply). This is in line with the classification in Kuttner and Shim (2016).

\section{Appendix IV Table 1. Variable Descriptions and Sources}

\begin{tabular}{|c|c|c|}
\hline Variables & Description & Source \\
\hline \multicolumn{3}{|l|}{ Macro-level Variables } \\
\hline Household Debt & $\begin{array}{l}\text { Credit to households and NPISHs from all sectors, in billions, } \\
\text { national currency. }\end{array}$ & $\begin{array}{l}\text { BIS; JST; CEIC; ECRI; Haver } \\
\text { Analytics; STA-SRF; Central } \\
\text { Banks. }\end{array}$ \\
\hline Real GDP & Gross domestic product, constant prices in national currency & WEO. \\
\hline Consumer Price Index & Consumer price index, all items. & IFS. \\
\hline Interest Rate & $\begin{array}{l}\text { Three-month treasury bill rate; money market rate; interbank } \\
\text { market rate (percent). }\end{array}$ & $\begin{array}{l}\text { IFS; Thomson Reuters } \\
\text { Datastream; Bloomberg Finance } \\
\text { L.P. }\end{array}$ \\
\hline Real House Price Index & House price index deflated by $\mathrm{CPI}$. & $\begin{array}{l}\text { OECD, Global Property Guide, } \\
\text { and IMF staff calculations; JST. }\end{array}$ \\
\hline \multicolumn{3}{|l|}{ Institutional Variables } \\
\hline Financial Development Index & Overall financial development index. & Svirydzenka (2016). \\
\hline Exchange Rate Regime & Foreign exchange regime. & $\begin{array}{l}\text { IMF, Ilzetzki, Reinhart and Rogoff } \\
\text { (2017). }\end{array}$ \\
\hline Debt-to-income Ratio & $\begin{array}{l}\text { Debt-to-income of lower-income borrowers (bottom } 40 \text { percent } \\
\text { of the income distribution). }\end{array}$ & Alter, Feng, and Valckx (2018). \\
\hline $\begin{array}{l}\text { Capital Openness Index } \\
\text { (Chinn-Ito Index) }\end{array}$ & $\begin{array}{l}\text { An index measuring a country's degree of capital account } \\
\text { openness. }\end{array}$ & $\begin{array}{l}\text { Chinn, Menzie D. and Hiro Ito } \\
\text { (2008). }\end{array}$ \\
\hline
\end{tabular}

Sources: Authors.

Notes: BIS = Bank for International Settlements; CEIC = CEIC Data Co., Ltd.; HPDD = Historical Public Debt Database; IFS

= IMF, International Financial Statistics Database; JST = Jordà-Schularick-Taylor Macrohistory Database; OECD =

Organisation for Economic Co-operation and Development; WEO = World Economic Outlook Database. 


\section{Appendix IV Table 2. Sample Economies for the Panel Regression Analysis}

\begin{tabular}{|c|c|c|c|}
\hline \multicolumn{2}{|c|}{ Advanced Economies (AEs) } & \multicolumn{2}{|c|}{ Emerging Market and Developing Economies (EMDEs) } \\
\hline 1 & Australia & 1 & Argentina \\
\hline 2 & Austria & 2 & Brazil \\
\hline 3 & Belgium & 3 & Bulgaria \\
\hline 4 & Canada & 4 & Chile \\
\hline 5 & Cyprus & 5 & China \\
\hline 6 & Czech Republic & 6 & Colombia \\
\hline 7 & Denmark & 7 & Costa Rica \\
\hline 8 & Estonia & 8 & Croatia \\
\hline 9 & Finland & 9 & Georgia \\
\hline 10 & France & 10 & Hungary \\
\hline 11 & Germany & 11 & India \\
\hline 12 & Greece & 12 & Indonesia \\
\hline 13 & Hong Kong & 13 & Kazakhstan \\
\hline 14 & Iceland & 14 & Macedonia \\
\hline 15 & Ireland & 15 & Malaysia \\
\hline 16 & Israel & 16 & Mexico \\
\hline 17 & Italy & 17 & Mongolia \\
\hline 18 & Japan & 18 & Morocco \\
\hline 19 & Latvia & 19 & Paraguay \\
\hline 20 & Lithuania & 20 & Philippines \\
\hline 21 & Luxembourg & 21 & Poland \\
\hline 22 & Netherlands & 22 & Romania \\
\hline 23 & New Zealand & 23 & Russia \\
\hline 24 & Norway & 24 & Saudi Arabia \\
\hline 25 & Portugal & 25 & South Africa \\
\hline 26 & Singapore & 26 & Thailand \\
\hline 27 & Slovak Republic & 27 & Turkey \\
\hline 28 & Slovenia & 28 & Ukraine \\
\hline 29 & South Korea & 29 & Uruguay \\
\hline 30 & Spain & & \\
\hline 31 & Sweden & & \\
\hline 32 & Switzerland & & \\
\hline 33 & United Kingdom & & \\
\hline 34 & United States & & \\
\hline
\end{tabular}




\section{Appendix IV Table 3. Summary Statistics}

\begin{tabular}{|c|c|c|c|c|c|c|}
\hline & \multicolumn{2}{|c|}{ ALL } & \multicolumn{2}{|c|}{$\mathrm{AE}$} & \multicolumn{2}{|c|}{ EMDE } \\
\hline & mean & sd & mean & sd & mean & sd \\
\hline \multicolumn{7}{|l|}{ Macro-financial variables } \\
\hline Household Debt (yoy, real, \%change) & 7.806 & 13.519 & 5.613 & 9.470 & 11.641 & 17.961 \\
\hline Private Consumption (yoy, real, \%chang $\epsilon$ & -0.800 & 5.848 & 0.090 & 4.091 & -2.511 & 7.958 \\
\hline House Prices (yoy, real, \%change) & 1.728 & 8.667 & 1.746 & 8.406 & 1.686 & 9.289 \\
\hline Real GDP (yoy, real, \%change) & 2.859 & 3.239 & 2.355 & 2.950 & 3.740 & 3.522 \\
\hline Short-term Interest Rates (level) & 9.705 & 9.969 & 6.480 & 3.884 & 15.346 & 14.032 \\
\hline \multicolumn{7}{|l|}{ Aggregated MaPP Indices } \\
\hline Mapp index (all measures, yoy mean) & 0.081 & 0.368 & 0.051 & 0.265 & 0.132 & 0.496 \\
\hline All Loan-related (yoy mean) & 0.033 & 0.177 & 0.030 & 0.156 & 0.039 & 0.209 \\
\hline Demand (yoy mean) & 0.019 & 0.119 & 0.018 & 0.119 & 0.020 & 0.119 \\
\hline Supply All (yoy mean) & 0.044 & 0.285 & 0.016 & 0.180 & 0.092 & 0.403 \\
\hline Supply Loan (yoy mean) & 0.014 & 0.102 & 0.011 & 0.074 & 0.019 & 0.138 \\
\hline Supply General (yoy mean) & 0.005 & 0.225 & -0.015 & 0.121 & 0.039 & 0.335 \\
\hline Supply Capital (yoy mean) & 0.029 & 0.116 & 0.021 & 0.096 & 0.043 & 0.143 \\
\hline \multicolumn{7}{|l|}{ Individual MaPP Indices } \\
\hline 1 CCB (yoy mean) & 0.001 & 0.024 & 0.002 & 0.023 & 0.000 & 0.025 \\
\hline 2 CONSERVATION B. (yoy mean) & 0.007 & 0.044 & 0.006 & 0.043 & 0.009 & 0.047 \\
\hline 3 CAPITAL (yoy mean) & 0.018 & 0.095 & 0.012 & 0.075 & 0.029 & 0.123 \\
\hline 4 LVR (yoy mean) & 0.003 & 0.026 & 0.002 & 0.020 & 0.005 & 0.034 \\
\hline 5 LLP (yoy mean) & 0.004 & 0.046 & 0.002 & 0.034 & 0.006 & 0.063 \\
\hline 6 LCG (yoy mean) & 0.000 & 0.035 & 0.000 & 0.019 & 0.000 & 0.053 \\
\hline 7 LOANR (yoy mean) & 0.007 & 0.061 & 0.005 & 0.051 & 0.011 & 0.074 \\
\hline 8 LFC (yoy mean) & 0.003 & 0.033 & 0.003 & 0.030 & 0.002 & 0.038 \\
\hline 9 LTV (yoy mean) & 0.012 & 0.089 & 0.012 & 0.087 & 0.013 & 0.094 \\
\hline 10 DSTI (yoy mean) & 0.007 & 0.054 & 0.006 & 0.054 & 0.007 & 0.052 \\
\hline 11 TAX (yoy mean) & 0.006 & 0.049 & 0.005 & 0.044 & 0.006 & 0.057 \\
\hline 12 Liquidity (yoy mean) & 0.006 & 0.063 & 0.005 & 0.049 & 0.009 & 0.082 \\
\hline 13 LTD (yoy mean) & 0.000 & 0.019 & 0.001 & 0.013 & 0.000 & 0.027 \\
\hline 14 LFX (yoy mean) & 0.002 & 0.037 & 0.001 & 0.017 & 0.005 & 0.057 \\
\hline 15 RR (yoy mean) & -0.004 & 0.218 & -0.021 & 0.109 & 0.025 & 0.328 \\
\hline 16 SIFI (yoy mean) & 0.004 & 0.029 & 0.005 & 0.034 & 0.001 & 0.017 \\
\hline 17 OT (yoy mean) & 0.005 & 0.035 & 0.005 & 0.036 & 0.004 & 0.035 \\
\hline Average LTV Limit (change, percentage $p c$ & -0.197 & 2.392 & -0.154 & 1.900 & -0.271 & 3.049 \\
\hline
\end{tabular}

Sources: The iMaPP database, Bloomberg, BIS, OECD, others (see Appendix IV), and the authors' estimation.

Notes: Individual macroprudential variables and aggregated MaPP indices are presented as the year-on-year average (yoy mean). The MaPP index consists of all 17 individual macroprudential measures. All Loan-related consists of Demand-related and Supply Loan measures. Demand-related includes debt-service-to-income (DSTI) and loan-to-value (LTV) limits. Supply All measures are divided into General, Capital, and Loan. Supply General consists of reserve requirements (RR), liquidity requirements (LR), and limits on foreign exchange positions (LFX). Supply Capital consists of capital requirements (CAPITAL), conservation buffers (CONSERVATION B), the leverage ratio (LVR), capital surcharges for systemically important financial institutions (SIFI), and countercyclical capital buffers (CCB). Supply Loan consists of limits on credit growth (LCG), loan loss provisions (LLP), loan restrictions (LOANR), and limits on foreign currency loans (LFC). For further details, see Appendix I Table 3. Summary statistics are presented for the set of 63 countries used in the regression analysis. $A E=$ advanced economies; EMDE = emerging market and developing economies. 


\section{Appendix V. Robustness of the Panel Regression Results With Dummy-Type INDICATORS}

\section{System GMM results}

The inclusion of a lag of the dependent variable may lead to biased estimates (Nickell 1981), even though the time dimension is large in in our sample. Therefore, as a robustness exercise, we use System GMM techniques, following Arellano and Bover (1995) and Blundell and Bond (1998) and executing them using xtbond 2 in Stata (Roodman, 2009), and compare the estimates with the fixed effect estimates (see Appendix VIII Tables 1-4). This robustness check confirms that our baseline results are consistent with the GMM estimates, proving that the Nickell bias is marginal in this context. In general, magnitudes and significance are slightly stronger for the GMM estimates.

\section{Quantile regressions}

Quantile regressions help us examine the effects of macroprudential policy on the whole distribution of macro-financial variables, instead of focusing on average effects as in the baseline model. ${ }^{29}$ These results could indicate whether the policy is effective in reducing the probability of high credit growth, for example.

We estimate quantile panel regressions with non-additive fixed effects (Powell 2016; 2015; Koenker 2004; Koenker and Hallock 2001), conditional on an observable vector of the lag of country-specific variables $(X)$. Specifically, for each quantile $\tau$ (i.e., $10^{\text {th }}$ and $90^{\text {th }}$ percentile, respectively), the following equation is estimated:

$$
Q\left(Y_{i, t} \mid X_{i, t-1}, \tau\right)=\alpha_{i}(\tau)+\mu_{t}(\tau)+X_{i, t-1} \beta(\tau)+\epsilon_{i, t}(\tau),
$$

where $\alpha$ and $\mu$ are country- and time- fixed effects, respectively, and $\varepsilon$ the error terms.

The effects on household credit are found to be stronger in reducing the probability of credit booms (Appendix VIII Table 5, columns 3, 6, and 9). The results seem to be particularly relevant for AEs, reducing the $90^{\text {th }}$ percentile of the credit growth distribution significantly (column 6). In general, tightening measures affecting bank capital are found to mitigate the probability of high credit growth. For example, household credit at the $90^{\text {th }}$ percentile declines by about 2.5 percent when capital requirements are tightened, although the effects are not statistically significant on the lower tail (i.e., quantile $=0.1$, column 1 ). For AEs, the DSTI limits reduces the high credit episodes, slowing the $90^{\text {th }}$ percentile credit growth by 1.5 ppts, although their effects are not significant on average (FE) or at the lower tail

\footnotetext{
${ }^{29}$ In a separate exercise, we condition our baseline panel regressions on episodes with private credit gap positive for at least three quarters, i.e., during a protracted credit boom. Those findings are similar to the quantile regressions (at the $90^{\text {th }}$ percentile).
} 
(columns 4-6). Similarly, for house prices, we find stronger effects on the right tail of the distribution for selected measures (Appendix VIII Table 7).

The side effects also seem stronger at the right tail of the private consumption distribution for AEs (Appendix VIII Table 6). They are larger in magnitude when loan-targeted and demandside measures are deployed. For instance, LTV limits reduce private consumption growth by about one ppt at the $90^{\text {th }}$ percentile of its distribution, indicating a reduction of the probability of high consumption growth. They also appear to reduce the episodes of high real output growth (Appendix VIII Table 8). 


\section{APPENDIX VI. AIPW Estimation}

\section{Baseline AIPW estimation}

In Section IV, we use a propensity-score based approach, combined with a local projection method to estimate the policy effects for different horizons (Angrist and others 2016, Jordà and Taylor, 2016, and Richter and others 2018). Among many variants of propensity-score estimators, we chose the Augmented Inverse-Propensity-Score Weighted (AIPW) estimator, which is the most efficient estimator in the class of "doubly-robust" estimators. ${ }^{30}$

The AIPW estimator of the average treatment effect (ATE) is defined as follows:

$$
\widehat{\Delta}_{j}^{h, A I P W}=\frac{1}{N T} \sum_{t, n} \hat{\Delta}_{j n t}^{h, A I P W}
$$

where

$$
\hat{\Delta}_{j n t}^{h, A I P W}=\left\{\frac{D_{j n t} \cdot \Delta^{h} y_{n t}-\left(D_{j n t}-p_{j n t}\right) \cdot m_{j}\left(\boldsymbol{X}^{\boldsymbol{o}}\right)}{p_{j n t}}\right\}-\left\{\frac{D_{0 t} \cdot \Delta^{h} y_{n t}-\left(D_{0 n t}-p_{0 n t}\right) \cdot m_{0}\left(\boldsymbol{X}^{\boldsymbol{o}}\right)}{p_{0 n t}}\right\}
$$

$h$ is the horizon, $D_{j n t}$ is the dummy variable of treatment $j$ for country $n$ and time $t$ (with $j=0$ indicating the control group - i.e., no change in the average LTV limit), $p_{j n t}$ is the propensity score of treatment $j$, and $m_{j}\left(\boldsymbol{X}^{\boldsymbol{O}}\right)$ is the predicted outcome of treatment $j$. The AIPW estimation involves estimating (1) a treatment model to obtain the propensity scores and (2) outcome models to address the distortion due to the unobserved outcomes.

Treatment model: To obtain the propensity scores $\left(p_{j n t}\right)$, we estimate the following ordered logit model with time and country dummies for fixed effects and obtain the propensity scores

$$
z^{*}=X^{T} \beta^{T}+e
$$

where $z^{*}$ : dltv (=-20, -10, 0, 10, 20), and $\boldsymbol{X}^{\boldsymbol{T}}$ includes a lag of real household debt growth, a lag of real GDP growth, a lag of the interest rate, time-dummies, and country-dummies. Each value of dltv represents one of the following groups: a tightening of more than or equal to 10 ppts and less than 25 ppts (-20); a tightening of less than 10 ppts (-10); no change (0-the control group); an easing of less than 10 ppts (10); and an easing of more than or equal to 10 ppts (20).

Estimation with country- or time-dummies may generate inconsistent estimates due to the incidental parameters problem under fixed- $T$ ( or $N$ ). The bias is small, though, when $T$ (or $N$ ) is large, as in our case. ${ }^{31}$ Nevertheless, we tried alternative specifications (such as dropping

\footnotetext{
${ }^{30}$ See Lunceford and Davidian (2004) and Jordà and Taylor (2016), for example.

${ }^{31}$ See, e.g., Wooldridge (2010, p 612), Dickerson and others (2011).
} 
time dummies and adding the VIX and quarter dummies) and found that this did not affect the results much.

The estimated distribution of the propensity score for the treated and control units overlaps reasonably well (Appendix VI Figure 1). In the baseline, we truncate the inverse of the propensity scores at 10 to avoid the instability, as in Jordà and Taylor (2016). ${ }^{32} \mathrm{We}$ also tried different truncations (e.g., at 100) but this did not affect the results significantly.

\section{Appendix VI Figure 1. The Distributions of the Treatment Propensity Scores}

A tightening by more than or equal to 10 ppts and less than 25 ppts

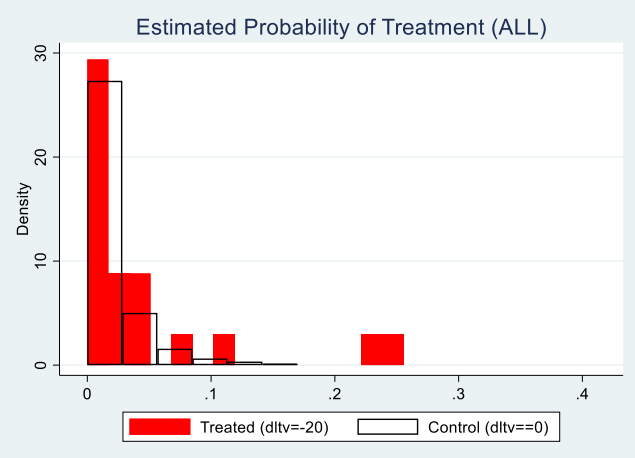

An easing by 0-10 ppts

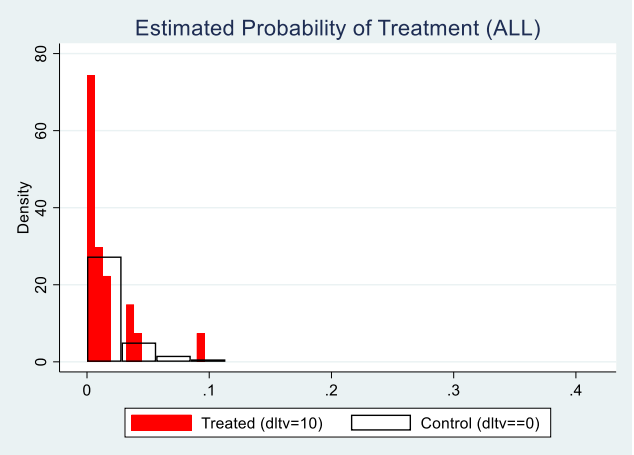

A tightening by less than 10 ppts

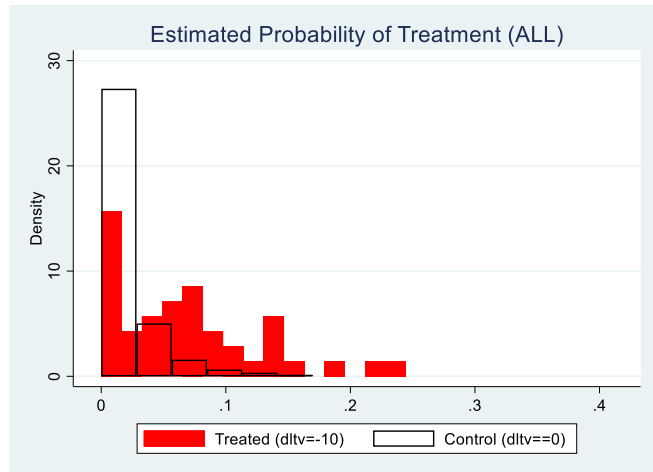

An easing by more than 10 ppts

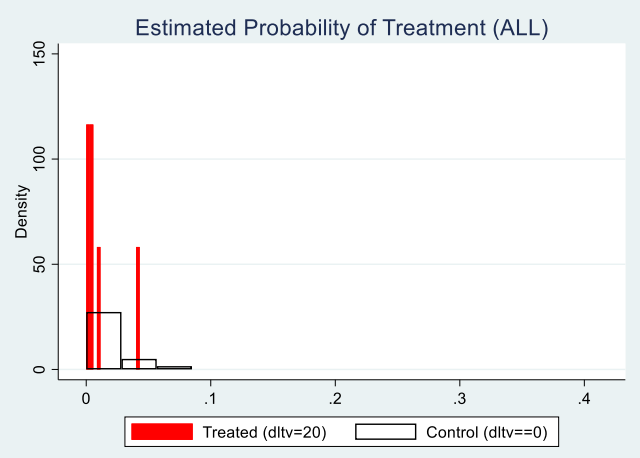

Sources: The iMaPP database, Bloomberg, BIS, OECD, others (see Appendix IV), and the authors' estimation. Notes: The propensity score is estimated using the ordered logit model. The treatment groups are (1) a tightening of greater than or equal to 10 ppts and less than 25 ppts, (2) a tightening of less than 10 ppts, (3) an easing by less than 10 ppts, and (4) an easing of greater than or equal to $10 \mathrm{ppts}$; and the control group is no change. Observations with $\Delta \mathrm{LTV}$ less than or equal to 25 ppts are excluded for the estimation to mitigate the influence of outliers. The figure shows the predicted probabilities of the specified treatment, with the red bars for the specified treatment group and the white bars for the control group.

Outcome model: To obtain the treatment-specific predicted outcomes $\left(m_{j}\left(\boldsymbol{X}^{\boldsymbol{O}}\right)\right)$, we estimate the following regression model for each treatment group and the control group:

$$
\Delta^{h} y_{t}=\sum_{s=0}^{L} \alpha_{s}^{h} \Delta y_{t-s}+\boldsymbol{X}^{\boldsymbol{o}} \boldsymbol{\beta}^{\boldsymbol{o}}+e
$$

\footnotetext{
${ }^{32}$ Since the propensity scores takes small values, the AIPW estimator could become unstable as the inverse of the propensity scores can take huge values.
} 
for horizon $(h=1,2, \ldots)$, where $y$ : outcome variable (e.g., log of real household credit), $\Delta^{h} y_{t}:=y_{t+h}-y_{t}, \Delta y_{t}:=y_{t}-y_{t-1}$, and $\boldsymbol{X}^{\boldsymbol{O}}$ includes real GDP growth (q-on-q), real shortterm interest rate, and VIX, with their one-quarter lags, as well as the dummies for AE, EMDE, and quarters. ${ }^{33} \mathrm{We}$ also tried different specifications and found that household credit and house price results are broadly robust while private consumption results are less robust.

Average treatment effect (ATE): With the predicted propensity scores $\left(p_{j n t}\right)$, and outcomes $\left(m_{j}\left(\boldsymbol{X}^{\boldsymbol{O}}\right)\right)$, the AIPW estimate of the ATE is obtained using equation (A.VI.1) for each treatment group. Specifically, we compute $\Delta_{j n t}^{h, A I P W}$ and regress it on a constant term to get the AIPW estimator and its standard error clustered by country, as in Jordà and Taylor (2016). Please note that these standard errors would miss the uncertainty in the treatmentand outcome- model estimation, and thus probably tend to be smaller-i.e., statistical significance tend to be overstated. A one-step estimation or a bootstrap method would be needed to obtain correct standard errors.

\section{AIPW estimation on the effects of initial LTV levels}

To examine whether the LTV effects differ across initial LTV levels (Section IV.C.), we estimate the AIPW model, excluding the observations with high initial LTV levels (i.e., $L T V_{t-1} \geq 100$ ), and compare it with the baseline results.

The AIPW estimates find a consistent result for the group of a tightening by less than 10 ppts. When excluding the observations with high initial LTV levels, the estimated effect on credit gets smaller but the side effect on consumption gets larger (Appendix IV Table 1). It is not feasible to provide the AIPW estimates for AEs and EMDEs, separately, due to the limited observation of LTV changes.

Appendix VI Table 1: AIPW Results - Effects of Initial LTV Levels

\begin{tabular}{|c|c|c|c|}
\hline & $\begin{array}{l}\text { Houshold } \\
\text { Credit }\end{array}$ & Consumption & $\begin{array}{c}\text { Number of } \\
\text { Observations } \\
\text { (dLTV) }\end{array}$ \\
\hline Baseline & $-0.65^{\star \star \star}$ & $-0.15^{*}$ & 46 \\
\hline w/o High Initial Levels ${ }^{1 /}$ & $-0.28^{*}$ & $0.34^{\star * *}$ & 37 \\
\hline
\end{tabular}

\footnotetext{
${ }^{33}$ Country and time fixed effect dummies cannot be used due to limited numbers of observations in some treatment groups. Instead, AE and EMDE dummies are used to control some country fixed effects, and quarter dummies and VIX are used to control some time fixed effects.
} 


\section{APPENDIX VII: QUANTIFYING THE EFFECTS OF LTV CHANGES (Identification based on the Timing Assumption)}

\section{Empirical design}

In section IV, in addition to the AIPW estimation, we also conduct panel regressions with various controls to quantify the effects of a one-percentage-point change in the LTV limit on real household credit growth and real private consumption. Specifically, we estimate the following equation:

$$
\Delta_{4} C_{i, t}=\rho \Delta_{4} C_{i, t-1}+\sum_{s=1}^{4} \beta_{s} \Delta L T V_{i, t-s}+\sum_{l=1}^{L} \gamma_{l} X_{i, t-l}+\alpha_{i}+\mu_{t}+\epsilon_{i, t},
$$

where $i$ is country, $t$ is the time (quarter). The dependent variable, $\Delta_{4} C_{i, t}$, refers to year-onyear growth rate of real household credit. $\Delta L T V_{i, t}$ is the percentage point changes in the average LTV limits in country $i$ and quarter $t$. The lags of $\Delta L T V_{i, t}$ are included to capture prolonged effects of policy changes on credit growth. When examining nonlinear effects, we replace $\Delta L T V_{i, t}$ with the interaction term $\Delta L T V_{i, t} \cdot Z_{i, t}$, where $Z_{i, t}$ is the dummy variable that takes one if $\Delta L T V_{i, t}$ is in a specified range (e.g., $\Delta L T V_{i, t} \in(-10,0)$ ) for Section IV.B.; and the initial LTV level for Section IV.C. The lag of $\Delta_{4} C_{i, t}$ is also included as a regressor to capture any autonomous dynamics in real credit growth, and a vector $\boldsymbol{X}_{i, t}$ includes other control variables, such as real GDP growth, domestic real interest rates and other macroprudential policies. Time $(t)$ and country $\left(\alpha_{i}\right)$ fixed effects capture time-varying common factors such as global risk aversion and time-invariant country-specific factors such as location or institutional characteristics.

The dependent variable refers to total private credit to household sector (in real terms), which includes both mortgage and consumer credit from all sources. ${ }^{34}$ When considering side effects, we replace the dependent variable with real private consumption growth. The identification of LTV effects is based on the timing assumption-LTV limits do not affect credit growth within the same quarter. The model is estimated with quarterly data from about 58 countries over the period 2000 Q1 to 2016 Q4 using panel regressions with fixed effects. ${ }^{35}$

To examine whether these effects differ across country characteristics, we estimate equation (A.VII.1) with country group subsamples (for instance, EMDE/AE; regions such as Asia, Europe, and Americas; among the countries with high exchange rate flexibility, high capital

\footnotetext{
${ }^{34}$ This choice is justified given that mortgage data are scarcer across countries and time than total household credit data.

${ }^{35}$ As a robustness check, we employ the system GMM technique, following Arellano and Bover (1995) and Blundell and Bond (1998). However, given our time span at the quarterly frequency, the so-called Nickell bias (Nickell 1981) should be less of a concern. For this robustness exercise see Appendix VIII Tables 13 and 14.
} 
openness, high financial development; countries with high debt-to-income ratios among lowincome borrowers), or conditioning on a positive credit gap. ${ }^{36}$

\section{Results: The effects of changes in the LTV limits}

First, we examine the effects of $\Delta \mathrm{LTV}$ limit on real household credit. Our main focus is the sum of the $\Delta \mathrm{LTV}$ coefficients, which encompasses the cumulative effects of the previous 4 lags (Appendix VIII Table 9). These effects are found significant for EMDEs, Asia and Pacific region, in countries with high indebtedness level of the low-income borrowers, as well as when credit gap is positive in EMDEs. The magnitude of a one ppt tightening of LTV limit on real household credit varies from about 0.07 ppts to 0.37 ppts. These estimates are similar to those presented in the previous sections. In addition, our results are comparable with those by Richter et al (2018).

Turning to the control variables, the positive and close-to-unity estimates of the lagged credit growth suggest a high degree of persistence in yearly credit growth. This coefficient ranges from a minimum of 0.82 for North and Latin American countries to a maximum of 0.97 in countries with high indebtedness level of the low-income borrowers. As expected, higher short-term interest rates are found to negatively impact future household credit growth. These interest rate effects are found slightly stronger in EMDEs than in AEs. Unsurprisingly, this relationship holds well for European countries, where the common monetary policy, trade and economic integration translates into a homogenous negative relationship. Lastly, the state of the business cycle is proxied by the past output growth, which is found to be positively associated with credit growth.

We also assess the impact of $\triangle \mathrm{LTV}$ on real private consumption (see Appendix VIII Table 10). The effects are significant when all countries are considered, as well as for the EMDE group, for countries with highly indebted low-income borrowers, and when EMDEs experience a credit boom. The magnitude of one ppt tightening of LTV limit on real private consumption vary from about 0.08 ppts to 0.18 ppts. ${ }^{37}$

These results are robust to controlling for other macroprudential policies (Appendix VIII Tables 11-12), and to the use of the Arellano-Bover-Blundell-Bond system GMM estimator (Appendix VIII Tables 13-14).

\footnotetext{
${ }^{36}$ Using micro-level household surveys, countries are split into high/low indebtedness of low-income borrowers if the average debt-to-income ratio of the bottom 40 percent households by income is above/below the median.

${ }^{37}$ Likewise, robustness checks show broadly significant and equal magnitudes for all countries, the EMDE group, or when EMDEs experience credit booms, when controlling for other macroprudential measures or using GMM techniques (see Appendix VIII Tables 12 and 14).
} 


\section{APPENDiX VIII. TABLES-REgRESSION ANALYSIS}

\section{Appendix VIII Table 1. Robustness: The Effects of Macroprudential Policies on Real Household Credit Growth}

\begin{tabular}{|c|c|c|c|c|c|c|}
\hline \multirow{4}{*}{$\begin{array}{l}\text { Group } \\
\text { Method }\end{array}$} & (1) & (2) & (3) & (4) & (5) & (6) \\
\hline & \multicolumn{6}{|c|}{ Dependent Variable: Real Household Credit (yoy growth) } \\
\hline & \multicolumn{2}{|c|}{ ALL } & \multicolumn{2}{|c|}{$\mathrm{AE}$} & \multicolumn{2}{|c|}{ EMDE } \\
\hline & $\mathrm{FE}$ & GMM & FE & GMM & FE & GMM \\
\hline MaPP (All, Sum) & $\begin{array}{c}-0.842^{* * *} \\
(0.296)\end{array}$ & $\begin{array}{c}-1.061^{* * *} \\
(0.321)\end{array}$ & $\begin{array}{l}-0.257 \\
(0.309)\end{array}$ & $\begin{array}{l}-0.382 \\
(0.316)\end{array}$ & $\begin{array}{c}-1.388^{* * *} \\
(0.395)\end{array}$ & $\begin{array}{c}-1.608^{\star \star *} \\
(0.388)\end{array}$ \\
\hline MaPP (Loan, Sum) & $\begin{array}{c}-1.883^{* * *} \\
(0.506)\end{array}$ & $\begin{array}{c}-2.443^{* * *} \\
(0.639)\end{array}$ & $\begin{array}{c}-1.043^{\star *} \\
(0.485)\end{array}$ & $\begin{array}{c}-1.301^{* *} \\
(0.515)\end{array}$ & $\begin{array}{c}-2.925^{\star * *} \\
(0.880)\end{array}$ & $\begin{array}{c}-3.564^{\star * *} \\
(1.081)\end{array}$ \\
\hline MaPP (Demand, Sum) & $\begin{array}{c}-1.994^{* * *} \\
(0.680)\end{array}$ & $\begin{array}{c}-2.706^{\star * *} \\
(0.844)\end{array}$ & $\begin{array}{l}-0.607 \\
(0.569)\end{array}$ & $\begin{array}{l}-0.740 \\
(0.637)\end{array}$ & $\begin{array}{c}-4.926^{* * *} \\
(1.709)\end{array}$ & $\begin{array}{c}-6.041^{* * *} \\
(1.729)\end{array}$ \\
\hline MaPP (Supply All, Sum) & $\begin{array}{l}-0.824^{*} \\
(0.418)\end{array}$ & $\begin{array}{c}-1.033^{* *} \\
(0.456)\end{array}$ & $\begin{array}{c}0.395 \\
(0.515)\end{array}$ & $\begin{array}{c}0.181 \\
(0.521)\end{array}$ & $\begin{array}{c}-1.511^{* * *} \\
(0.523)\end{array}$ & $\begin{array}{c}-1.747^{* * *} \\
(0.514)\end{array}$ \\
\hline MaPP (Supply Loans, Sum) & $\begin{array}{c}-2.931^{* * *} \\
(0.975)\end{array}$ & $\begin{array}{c}-3.801^{* * *} \\
(1.253)\end{array}$ & $\begin{array}{c}-3.028^{\star *} \\
(1.224)\end{array}$ & $\begin{array}{c}-4.314^{\star \star \star} \\
(1.457)\end{array}$ & $\begin{array}{c}-3.005^{\star *} \\
(1.182)\end{array}$ & $\begin{array}{c}-3.741^{\star * *} \\
(1.451)\end{array}$ \\
\hline MaPP (Supply General, Sum) & $\begin{array}{l}-0.602 \\
(0.627)\end{array}$ & $\begin{array}{l}-0.943 \\
(0.606)\end{array}$ & $\begin{array}{c}0.958 \\
(0.589)\end{array}$ & $\begin{array}{c}0.671 \\
(0.523)\end{array}$ & $\begin{array}{l}-1.354^{*} \\
(0.732)\end{array}$ & $\begin{array}{c}-1.683^{* *} \\
(0.679)\end{array}$ \\
\hline MaPP (Supply Capital, Sum) & $\begin{array}{l}-1.009 \\
(0.668)\end{array}$ & $\begin{array}{c}-1.667^{* *} \\
(0.796)\end{array}$ & $\begin{array}{c}0.221 \\
(0.607)\end{array}$ & $\begin{array}{c}0.304 \\
(0.728)\end{array}$ & $\begin{array}{l}-1.959^{*} \\
(0.960)\end{array}$ & $\begin{array}{c}-2.539^{\star * *} \\
(0.927)\end{array}$ \\
\hline dsti & $\begin{array}{c}-2.648^{\star \star \star} \\
(0.988)\end{array}$ & $\begin{array}{c}-3.015^{\star *} \\
(1.360)\end{array}$ & $\begin{array}{l}-1.231 \\
(1.028)\end{array}$ & $\begin{array}{l}-1.182 \\
(1.048)\end{array}$ & $\begin{array}{c}-6.173^{\star *} \\
(2.565)\end{array}$ & $\begin{array}{c}-7.245^{\star \star \star} \\
(2.465)\end{array}$ \\
\hline Itv & $\begin{array}{c}-2.557^{* *} \\
(1.060)\end{array}$ & $\begin{array}{c}-3.658^{* *} \\
(1.519)\end{array}$ & $\begin{array}{l}-0.654 \\
(1.035)\end{array}$ & $\begin{array}{l}-0.710 \\
(1.333)\end{array}$ & $\begin{array}{c}-5.797^{\star * *} \\
(1.718)\end{array}$ & $\begin{array}{c}-7.043^{* * *} \\
(1.911)\end{array}$ \\
\hline $\operatorname{tax}$ & $\begin{array}{c}-0.988 \\
(1.127)\end{array}$ & $\begin{array}{c}-0.807 \\
(1.080)\end{array}$ & $\begin{array}{l}-1.514 \\
(2.163)\end{array}$ & $\begin{array}{l}-1.091 \\
(1.855)\end{array}$ & $\begin{array}{l}-0.860 \\
(0.910)\end{array}$ & $\begin{array}{l}-0.837 \\
(0.898)\end{array}$ \\
\hline $\operatorname{lcg}$ & $\begin{array}{l}-4.620 \\
(3.229)\end{array}$ & $\begin{array}{c}-4.962 \\
(3.663)\end{array}$ & $\begin{array}{l}-2.142 \\
(1.412)\end{array}$ & $\begin{array}{l}-2.906 \\
(1.814)\end{array}$ & $\begin{array}{l}-6.562^{*} \\
(3.609)\end{array}$ & $\begin{array}{l}-6.738^{*} \\
(4.071)\end{array}$ \\
\hline$\| p$ & $\begin{array}{c}-5.865^{\star * *} \\
(2.037)\end{array}$ & $\begin{array}{c}-5.096^{* *} \\
(2.541)\end{array}$ & $\begin{array}{l}-4.161 \\
(2.675)\end{array}$ & $\begin{array}{l}-4.982^{*} \\
(2.733)\end{array}$ & $\begin{array}{c}-6.656^{\star \star *} \\
(2.363)\end{array}$ & $\begin{array}{c}-5.554^{* *} \\
(2.374)\end{array}$ \\
\hline loanr & $\begin{array}{c}-3.489^{* *} \\
(1.451)\end{array}$ & $\begin{array}{c}-6.056^{\star * \star} \\
(1.560)\end{array}$ & $\begin{array}{c}-4.592^{\star *} \\
(1.923)\end{array}$ & $\begin{array}{c}-5.023^{\star *} \\
(2.024)\end{array}$ & $\begin{array}{l}-2.885 \\
(2.128)\end{array}$ & $\begin{array}{l}-3.799^{*} \\
(2.090)\end{array}$ \\
\hline capital & $\begin{array}{l}-1.091 \\
(0.899)\end{array}$ & $\begin{array}{l}-1.675^{*} \\
(0.905)\end{array}$ & $\begin{array}{l}0.0547 \\
(0.869)\end{array}$ & $\begin{array}{c}0.303 \\
(0.980)\end{array}$ & $\begin{array}{c}-1.803 \\
(1.233)\end{array}$ & $\begin{array}{l}-2.284^{*} \\
(1.166)\end{array}$ \\
\hline Observations & 4,492 & 4,492 & 2,858 & 2,858 & 1,634 & 1,634 \\
\hline$N$ (countries) & 63 & 63 & 34 & 34 & 29 & 29 \\
\hline R-squared (avg) & 0.884 & & 0.873 & & 0.903 & \\
\hline AR(1) Test (avg) & & $8.48 \mathrm{e}-05$ & & 0.022 & & 0.000 \\
\hline AR(2) Test (avg) & & 0.179 & & 0.285 & & 0.351 \\
\hline
\end{tabular}

Sources: The iMaPP database, Bloomberg, BIS, OECD, others (see Appendix IV), and the authors' estimation. Notes: The table reports the cumulative effects of the specified macroprudential tightening on real household credit growth after four quarters, obtained by the fixed effects (FE) estimation and the Arellano-Bover-Blundell-Bond system GMM estimation, both with the timing assumption. In addition to country and time fixed effects, each specification includes the lagged dependent variable, real output growth (lag), and domestic interest rates (lag). Each macroprudential policy indicator is the average over the previous four quarters and is considered individually. Period sample: 1991Q1-2016Q4. AE = advanced economies; and EMDE = emerging market and developing economies. P-values of the Arellano-Bond tests for $A R(1)$ and $A R(2)$ in first differences are reported. Standard errors clustered at the country-level are reported in parentheses. Confidence levels: ${ }^{* * *}$ $p<0.01,{ }^{* *} p<0.05,{ }^{*} p<0.1$ 


\section{Appendix VIII Table 2. Robustness: The Effects of Macroprudential Policies on Real Private Consumption Growth}

\begin{tabular}{|c|c|c|c|c|c|c|}
\hline \multirow{4}{*}{$\begin{array}{l}\text { Group } \\
\text { Method }\end{array}$} & (1) & (2) & (3) & (4) & (5) & (6) \\
\hline & \multicolumn{6}{|c|}{ Dependent Variable: Real Consumption (yoy growth) } \\
\hline & \multicolumn{2}{|c|}{ ALL } & \multicolumn{2}{|c|}{$\mathrm{AE}$} & \multicolumn{2}{|c|}{ EMDE } \\
\hline & $\mathrm{FE}$ & GMM & FE & GMM & FE & GMM \\
\hline MaPP (All, Sum) & $\begin{array}{l}-0.150 \\
(0.151)\end{array}$ & $\begin{array}{l}-0.133 \\
(0.174)\end{array}$ & $\begin{array}{l}-0.170 \\
(0.134)\end{array}$ & $\begin{array}{c}-0.182 \\
(0.144)\end{array}$ & $\begin{array}{l}-0.197 \\
(0.239)\end{array}$ & $\begin{array}{l}-0.145 \\
(0.225)\end{array}$ \\
\hline MaPP (Loan, Sum) & $\begin{array}{c}-0.999^{* * *} \\
(0.308)\end{array}$ & $\begin{array}{c}-0.990^{* * *} \\
(0.382)\end{array}$ & $\begin{array}{c}-0.888^{* *} \\
(0.323)\end{array}$ & $\begin{array}{c}-0.981^{\star \star *} \\
(0.372)\end{array}$ & $\begin{array}{l}-0.914 \\
(0.539)\end{array}$ & $\begin{array}{l}-1.049 \\
(0.699)\end{array}$ \\
\hline MaPP (Demand, Sum) & $\begin{array}{l}-0.649^{*} \\
(0.342)\end{array}$ & $\begin{array}{l}-0.723^{*} \\
(0.424)\end{array}$ & $\begin{array}{l}-0.527^{*} \\
(0.266)\end{array}$ & $\begin{array}{l}-0.496 \\
(0.391)\end{array}$ & $\begin{array}{l}-0.607 \\
(0.958)\end{array}$ & $\begin{array}{l}-0.133 \\
(0.929)\end{array}$ \\
\hline MaPP (Supply All, Sum) & $\begin{array}{l}0.0964 \\
(0.224)\end{array}$ & $\begin{array}{c}0.161 \\
(0.257)\end{array}$ & $\begin{array}{c}0.476 \\
(0.350)\end{array}$ & $\begin{array}{c}0.574 \\
(0.408)\end{array}$ & $\begin{array}{l}-0.176 \\
(0.287)\end{array}$ & $\begin{array}{l}-0.107 \\
(0.262)\end{array}$ \\
\hline MaPP (Supply Loans, Sum) & $\begin{array}{c}-2.006^{* *} \\
(0.760)\end{array}$ & $\begin{array}{c}-1.950^{* *} \\
(0.851)\end{array}$ & $\begin{array}{l}-2.707^{* *} \\
(1.042)\end{array}$ & $\begin{array}{c}-3.356^{\star \star *} \\
(1.056)\end{array}$ & $\begin{array}{l}-1.370 \\
(0.923)\end{array}$ & $\begin{array}{l}-1.711^{*} \\
(0.996)\end{array}$ \\
\hline MaPP (Supply General, Sum) & $\begin{array}{c}0.359 \\
(0.307)\end{array}$ & $\begin{array}{c}0.252 \\
(0.336)\end{array}$ & $\begin{array}{l}0.998^{*} \\
(0.492)\end{array}$ & $\begin{array}{l}0.990^{*} \\
(0.540)\end{array}$ & $\begin{array}{l}0.0276 \\
(0.408)\end{array}$ & $\begin{array}{l}0.0211 \\
(0.411)\end{array}$ \\
\hline MaPP (Supply Capital, Sum) & $\begin{array}{l}-0.137 \\
(0.454)\end{array}$ & $\begin{array}{c}0.488 \\
(0.647)\end{array}$ & $\begin{array}{l}-0.0225 \\
(0.644)\end{array}$ & $\begin{array}{c}0.387 \\
(0.781)\end{array}$ & $\begin{array}{l}-0.453 \\
(0.734)\end{array}$ & $\begin{array}{c}0.106 \\
(0.954)\end{array}$ \\
\hline dsti & $\begin{array}{l}-1.054 \\
(1.120)\end{array}$ & $\begin{array}{l}-0.0933 \\
(1.105)\end{array}$ & $\begin{array}{l}-1.066 \\
(0.973)\end{array}$ & $\begin{array}{l}-1.206 \\
(1.076)\end{array}$ & $\begin{array}{l}-1.569 \\
(2.917)\end{array}$ & $\begin{array}{l}-0.420 \\
(2.939)\end{array}$ \\
\hline Itv & $\begin{array}{l}-0.778^{*} \\
(0.437)\end{array}$ & $\begin{array}{c}-1.243^{* *} \\
(0.604)\end{array}$ & $\begin{array}{l}-0.573 \\
(0.382)\end{array}$ & $\begin{array}{l}-0.492 \\
(0.523)\end{array}$ & $\begin{array}{l}-0.378 \\
(0.935)\end{array}$ & $\begin{array}{l}0.0559 \\
(1.083)\end{array}$ \\
\hline $\operatorname{tax}$ & $\begin{array}{l}-1.446 \\
(0.973)\end{array}$ & $\begin{array}{l}-1.387 \\
(1.048)\end{array}$ & $\begin{array}{l}-1.685 \\
(1.545)\end{array}$ & $\begin{array}{l}-1.333 \\
(1.651)\end{array}$ & $\begin{array}{c}-1.394^{* *} \\
(0.612)\end{array}$ & $\begin{array}{l}-1.518^{* *} \\
(0.760)\end{array}$ \\
\hline $\operatorname{lcg}$ & $\begin{array}{c}0.638 \\
(0.991)\end{array}$ & $\begin{array}{c}0.575 \\
(0.953)\end{array}$ & $\begin{array}{c}0.513 \\
(0.553)\end{array}$ & $\begin{array}{c}-0.557 \\
(1.170)\end{array}$ & $\begin{array}{c}0.377 \\
(1.195)\end{array}$ & $\begin{array}{c}0.430 \\
(1.471)\end{array}$ \\
\hline$\| p$ & $\begin{array}{l}-2.153 \\
(1.293)\end{array}$ & $\begin{array}{l}-1.966 \\
(1.244)\end{array}$ & $\begin{array}{l}-2.193^{*} \\
(1.276)\end{array}$ & $\begin{array}{l}-2.461^{*} \\
(1.398)\end{array}$ & $\begin{array}{l}-2.176 \\
(1.433)\end{array}$ & $\begin{array}{l}-2.061 \\
(1.384)\end{array}$ \\
\hline loanr & $\begin{array}{c}-3.841^{* * *} \\
(1.344)\end{array}$ & $\begin{array}{c}-4.346^{* * *} \\
(1.320)\end{array}$ & $\begin{array}{l}-4.267^{* *} \\
(1.610)\end{array}$ & $\begin{array}{c}-5.009^{* * *} \\
(1.671)\end{array}$ & $\begin{array}{l}-2.486 \\
(2.223)\end{array}$ & $\begin{array}{l}-3.628^{*} \\
(2.183)\end{array}$ \\
\hline capital & $\begin{array}{r}-0.0605 \\
(0.562)\end{array}$ & $\begin{array}{c}0.440 \\
(0.750)\end{array}$ & $\begin{array}{c}0.175 \\
(0.861)\end{array}$ & $\begin{array}{c}0.403 \\
(1.001)\end{array}$ & $\begin{array}{l}-0.318 \\
(0.836)\end{array}$ & $\begin{array}{c}0.133 \\
(1.138)\end{array}$ \\
\hline Observations & 4,639 & 4,639 & 2,863 & 2,863 & 1,776 & 1,776 \\
\hline $\mathrm{N}$ (countries) & 55 & 55 & 31 & 31 & 24 & 24 \\
\hline R-squared (avg) & 0.775 & & 0.771 & & 0.792 & \\
\hline AR(1) Test (avg) & & $5.28 \mathrm{e}-05$ & & 0.000 & & 0.003 \\
\hline AR(2) Test (avg) & & 0.0893 & & 0.713 & & 0.075 \\
\hline
\end{tabular}

Sources: The iMaPP database, Bloomberg, BIS, OECD, others (see Appendix IV), and the authors' estimation. Notes: The table reports the cumulative effects of the specified macroprudential tightening after four quarters, obtained by the fixed effects (FE) estimation and the Arellano-Bover-Blundell-Bond system GMM estimation, both with the timing assumption. In addition to country and time fixed effects, each specification includes the lagged dependent variable, real output growth (lag), and domestic interest rates (lag). Each macroprudential policy indicator is the average over the previous four quarters and is considered individually. Period sample: 1991Q1 - 2016Q4. AE = advanced economies; and EMDE = emerging market and developing economies. P-values of the Arellano-Bond tests for $A R(1)$ and $A R(2)$ in first differences are reported. Standard errors clustered at the country-level are reported in parentheses. Confidence levels: ${ }^{\star \star \star} p<0.01,{ }^{* \star} p<0.05,{ }^{*} p<0.1$ 


\section{Appendix VIII Table 3. Robustness: The Effects of Macroprudential Policies on Real House Price Growth}

\begin{tabular}{|c|c|c|c|c|c|c|}
\hline \multirow{4}{*}{$\frac{\text { Group }}{\text { Method }}$} & (1) & (2) & (3) & (4) & (5) & $(6)$ \\
\hline & \multicolumn{6}{|c|}{ Dependent Variable: Real Consumption (yoy growth) } \\
\hline & \multicolumn{2}{|c|}{ ALL } & \multicolumn{2}{|c|}{$\mathrm{AE}$} & \multicolumn{2}{|c|}{ EMDE } \\
\hline & $\mathrm{FE}$ & GMM & $\mathrm{FE}$ & GMM & $\mathrm{FE}$ & GMM \\
\hline MaPP (All, Sum) & $\begin{array}{l}-0.0877 \\
(0.199)\end{array}$ & -0.120 & $-0.898^{* *}$ & $-0.945^{\star}$ & 0.0619 & 0.0501 \\
\hline MaPP (Loan, Sum) & $\begin{array}{c}-1.066^{\star *} \\
(0.478)\end{array}$ & $\begin{array}{c}-1.337^{\star *} \\
(0.578)\end{array}$ & $\begin{array}{c}-1.667^{\star *} \\
(0.752)\end{array}$ & $\begin{array}{c}-1.850^{* *} \\
(0.876)\end{array}$ & $\begin{array}{l}-0.615 \\
(0.759)\end{array}$ & $\begin{array}{l}-0.625 \\
(0.670)\end{array}$ \\
\hline MaPP (Demand, Sum) & $\begin{array}{c}-1.406^{\star *} \\
(0.625)\end{array}$ & $\begin{array}{c}-1.774^{* *} \\
(0.702)\end{array}$ & $\begin{array}{c}-2.049^{* *} \\
(0.822)\end{array}$ & $\begin{array}{c}-2.146^{* *} \\
(0.960)\end{array}$ & $\begin{array}{c}-0.213 \\
(1.497)\end{array}$ & $\begin{array}{l}-0.0351 \\
(1.344)\end{array}$ \\
\hline MaPP (Supply All, Sum) & $\begin{array}{c}0.253 \\
(0.293)\end{array}$ & $\begin{array}{c}0.317 \\
(0.326)\end{array}$ & $\begin{array}{l}0.0116 \\
(0.474)\end{array}$ & $\begin{array}{c}0.115 \\
(0.544)\end{array}$ & $\begin{array}{c}0.00789 \\
(0.356)\end{array}$ & $\begin{array}{c}0.330 \\
(0.511)\end{array}$ \\
\hline MaPP (Supply Loans, Sum) & $\begin{array}{l}-1.191 \\
(0.774)\end{array}$ & $\begin{array}{c}-1.797^{*} \\
(0.942)\end{array}$ & $\begin{array}{l}-1.970 \\
(1.242)\end{array}$ & $\begin{array}{c}-2.718^{* *} \\
(1.172)\end{array}$ & $\begin{array}{l}-1.191 \\
(0.891)\end{array}$ & $\begin{array}{l}-1.429 \\
(0.886)\end{array}$ \\
\hline MaPP (Supply General, Sum) & $\begin{array}{c}0.485 \\
(0.400)\end{array}$ & $\begin{array}{c}0.782^{*} \\
(0.455)\end{array}$ & $\begin{array}{l}0.0313 \\
(0.546)\end{array}$ & $\begin{array}{c}0.357 \\
(0.529)\end{array}$ & $\begin{array}{c}0.175 \\
(0.528)\end{array}$ & $\begin{array}{c}0.254 \\
(0.544)\end{array}$ \\
\hline MaPP (Supply Capital, Sum) & $\begin{array}{c}0.270 \\
(0.706)\end{array}$ & $\begin{array}{l}-0.562 \\
(0.896)\end{array}$ & $\begin{array}{l}0.0689 \\
(1.192)\end{array}$ & $\begin{array}{l}-0.468 \\
(1.528)\end{array}$ & $\begin{array}{c}0.459 \\
(0.916)\end{array}$ & $\begin{array}{l}-0.442 \\
(1.049)\end{array}$ \\
\hline dsti & $\begin{array}{l}-1.455 \\
(1.681)\end{array}$ & $\begin{array}{l}-1.923 \\
(1.914)\end{array}$ & $\begin{array}{l}-3.167 \\
(2.577)\end{array}$ & $\begin{array}{l}-2.534 \\
(2.640)\end{array}$ & $\begin{array}{c}2.537 \\
(2.285)\end{array}$ & $\begin{array}{c}2.205 \\
(1.802)\end{array}$ \\
\hline Itv & $\begin{array}{c}-1.952^{* * *} \\
(0.708)\end{array}$ & $\begin{array}{c}-2.127^{* * *} \\
(0.723)\end{array}$ & $\begin{array}{c}-2.627^{* * *} \\
(0.632)\end{array}$ & $\begin{array}{c}-2.894^{* * *} \\
(0.689)\end{array}$ & $\begin{array}{l}-1.020 \\
(1.956)\end{array}$ & $\begin{array}{l}-0.573 \\
(1.888)\end{array}$ \\
\hline $\operatorname{tax}$ & $\begin{array}{l}-0.597 \\
(2.131)\end{array}$ & $\begin{array}{l}-0.682 \\
(2.476)\end{array}$ & $\begin{array}{c}-5.159^{* *} \\
(2.492)\end{array}$ & $\begin{array}{c}-5.540^{* *} \\
(2.489)\end{array}$ & $\begin{array}{c}3.235^{\star * *} \\
(0.768)\end{array}$ & $\begin{array}{r}4.761^{* * *} \\
(1.365)\end{array}$ \\
\hline $\operatorname{lcg}$ & $\begin{array}{l}-1.965 \\
(2.313)\end{array}$ & $\begin{array}{l}-1.433 \\
(2.809)\end{array}$ & $\begin{array}{l}-0.0586 \\
(0.759)\end{array}$ & $\begin{array}{l}-0.203 \\
(1.396)\end{array}$ & $\begin{array}{l}-2.436 \\
(2.284)\end{array}$ & $\begin{array}{l}-1.190 \\
(2.510)\end{array}$ \\
\hline$\| p$ & $\begin{array}{c}-2.987^{* *} \\
(1.191)\end{array}$ & $\begin{array}{c}-3.733^{\star * *} \\
(1.184)\end{array}$ & $\begin{array}{l}-1.510 \\
(1.145)\end{array}$ & $\begin{array}{l}-1.104 \\
(1.517)\end{array}$ & $\begin{array}{c}-4.529^{* *} \\
(1.938)\end{array}$ & $\begin{array}{c}-5.712^{* \star *} \\
(2.115)\end{array}$ \\
\hline loanr & $\begin{array}{l}-1.385 \\
(1.542)\end{array}$ & $\begin{array}{l}-2.379 \\
(1.590)\end{array}$ & $\begin{array}{l}-4.164^{*} \\
(2.208)\end{array}$ & $\begin{array}{c}-5.895^{\star *} \\
(2.305)\end{array}$ & $\begin{array}{l}-0.262 \\
(2.247)\end{array}$ & $\begin{array}{r}-0.0207 \\
(2.029)\end{array}$ \\
\hline capital & $\begin{array}{c}0.304 \\
(0.898)\end{array}$ & $\begin{array}{l}-0.671 \\
(1.050)\end{array}$ & $\begin{array}{l}-0.157 \\
(1.501)\end{array}$ & $\begin{array}{l}-0.293 \\
(1.742)\end{array}$ & $\begin{array}{c}0.582 \\
(1.093)\end{array}$ & $\begin{array}{l}-0.719 \\
(1.277)\end{array}$ \\
\hline Observations & 4,111 & 4,111 & 2,780 & 2,780 & 1,331 & 1,331 \\
\hline$N$ (countries) & 55 & 55 & 34 & 34 & 21 & 21 \\
\hline R-squared (avg) & 0.812 & & 0.846 & & 0.786 & \\
\hline AR(1) Test (avg) & & 0.007 & & 0.091 & & 0.013 \\
\hline AR(2) Test (avg) & & 0.610 & & 0.693 & & 0.644 \\
\hline
\end{tabular}

Sources: The iMaPP database, Bloomberg, BIS, OECD, others (see Appendix IV), and the authors' estimation. Notes: The table reports the cumulative effects of the specified macroprudential tightening after four quarters, obtained by the fixed effects (FE) estimation and the Arellano-Bover-Blundell-Bond system GMM estimation, both with the timing assumption. In addition to country and time fixed effects, each specification includes the lagged dependent variable, real output growth (lag), and domestic interest rates (lag). Each macroprudential policy indicator is the average over the previous four quarters and is considered individually. Period sample: 1991Q1 - 2016Q4. AE = advanced economies; and EMDE = emerging market and developing economies. P-values of the Arellano-Bond tests for $A R(1)$ and $A R(2)$ in first differences are reported. Standard errors clustered at the country-level are reported in parentheses. Confidence levels: ${ }^{* \star *} p<0.01,{ }^{* \star} p<0.05,{ }^{*} p<0.1$ 


\section{Appendix VIII Table 4. Robustness: The Effects of Macroprudential Policies on Real GDP Growth}

\begin{tabular}{|c|c|c|c|c|c|c|}
\hline \multirow{4}{*}{$\begin{array}{l}\text { Group } \\
\text { Method }\end{array}$} & (1) & (2) & (3) & (4) & (5) & (6) \\
\hline & \multicolumn{6}{|c|}{ Dependent Variable: Real GDP (yoy growth) } \\
\hline & \multicolumn{2}{|c|}{ ALL } & \multicolumn{2}{|c|}{$\mathrm{AE}$} & \multicolumn{2}{|c|}{ EMDE } \\
\hline & FE & GMM & FE & GMM & FE & GMM \\
\hline \multirow[t]{2}{*}{ MaPP (All, Sum) } & 0.0466 & 0.0108 & -0.0414 & -0.0647 & 0.0427 & -0.00523 \\
\hline & $(0.0558)$ & $(0.0720)$ & $(0.0657)$ & $(0.0853)$ & $(0.0757)$ & $(0.0818)$ \\
\hline \multirow[t]{2}{*}{ MaPP (Loan, Sum) } & -0.0729 & -0.165 & -0.119 & -0.192 & -0.0582 & -0.194 \\
\hline & $(0.119)$ & $(0.174)$ & $(0.147)$ & $(0.192)$ & $(0.177)$ & $(0.192)$ \\
\hline \multirow[t]{2}{*}{ MaPP (Demand, Sum) } & -0.112 & -0.248 & -0.131 & -0.190 & -0.138 & -0.224 \\
\hline & $(0.120)$ & $(0.191)$ & $(0.166)$ & $(0.211)$ & $(0.191)$ & $(0.234)$ \\
\hline \multirow[t]{2}{*}{ MaPP (Supply All, Sum) } & 0.0885 & 0.0612 & -0.0131 & -0.0354 & 0.0737 & 0.0351 \\
\hline & $(0.0826)$ & $(0.0958)$ & $(0.164)$ & $(0.180)$ & $(0.0989)$ & $(0.111)$ \\
\hline \multirow[t]{2}{*}{ MaPP (Supply Loans, Sum) } & -0.0633 & -0.203 & -0.179 & -0.346 & -0.0301 & -0.269 \\
\hline & $(0.243)$ & $(0.329)$ & $(0.352)$ & $(0.438)$ & $(0.301)$ & $(0.348)$ \\
\hline \multirow[t]{2}{*}{ MaPP (Supply General, Sum) } & 0.164 & 0.105 & -0.0314 & -0.105 & 0.163 & 0.141 \\
\hline & $(0.124)$ & $(0.138)$ & $(0.246)$ & $(0.273)$ & $(0.152)$ & $(0.161)$ \\
\hline \multirow[t]{2}{*}{ MaPP (Supply Capital, Sum) } & -0.118 & -0.108 & 0.103 & 0.239 & -0.360 & $-0.578^{*}$ \\
\hline & $(0.178)$ & $(0.250)$ & $(0.274)$ & $(0.374)$ & $(0.230)$ & $(0.306)$ \\
\hline \multirow[t]{2}{*}{ dsti } & -0.191 & -0.162 & -0.207 & -0.155 & -0.134 & -0.135 \\
\hline & $(0.343)$ & $(0.430)$ & $(0.532)$ & $(0.523)$ & $(0.277)$ & $(0.467)$ \\
\hline \multirow[t]{2}{*}{ Itv } & -0.127 & -0.326 & -0.163 & -0.244 & -0.176 & -0.285 \\
\hline & $(0.155)$ & $(0.272)$ & $(0.172)$ & $(0.218)$ & $(0.281)$ & $(0.333)$ \\
\hline \multirow[t]{2}{*}{$\operatorname{tax}$} & -0.0490 & -0.335 & -0.315 & -0.268 & 0.146 & -0.375 \\
\hline & $(0.233)$ & $(0.355)$ & $(0.360)$ & $(0.312)$ & $(0.262)$ & $(0.437)$ \\
\hline \multirow[t]{2}{*}{$\operatorname{lcg}$} & 0.197 & 0.105 & $-0.800^{* *}$ & $-0.775^{*}$ & 0.513 & 0.328 \\
\hline & (0.695) & $(0.762)$ & $(0.327)$ & $(0.395)$ & $(0.654)$ & $(0.766)$ \\
\hline \multirow[t]{2}{*}{$\| p$} & -0.482 & -0.417 & -0.614 & $-0.858^{*}$ & -0.482 & -0.625 \\
\hline & $(0.292)$ & $(0.375)$ & $(0.437)$ & $(0.454)$ & $(0.327)$ & $(0.388)$ \\
\hline \multirow[t]{2}{*}{ loanr } & 0.00843 & -0.252 & -0.0258 & -0.294 & -0.0511 & -0.400 \\
\hline & $(0.445)$ & $(0.605)$ & $(0.647)$ & $(0.788)$ & $(0.571)$ & (0.598) \\
\hline \multirow[t]{2}{*}{ capital } & 0.0150 & 0.0501 & 0.162 & 0.302 & -0.147 & -0.306 \\
\hline & $(0.221)$ & $(0.293)$ & $(0.393)$ & $(0.509)$ & $(0.264)$ & $(0.327)$ \\
\hline Observations & 5,416 & 5,416 & 3,125 & 3,125 & 2,291 & 2,291 \\
\hline $\mathrm{N}$ (countries) & 64 & 64 & 34 & 34 & 30 & 30 \\
\hline R-squared (avg) & 0.912 & & 0.931 & & 0.900 & \\
\hline AR(1) Test (avg) & & 0.0187 & & 0.051 & & 0.089 \\
\hline AR(2) Test (avg) & & 0.0706 & & 0.840 & & 0.072 \\
\hline
\end{tabular}

Sources: The iMaPP database, Bloomberg, BIS, OECD, others (see Appendix IV), and the authors' estimation. Notes: The table reports the cumulative effects of the specified macroprudential tightening after four quarters, obtained by the fixed effects (FE) estimation and the Arellano-Bover-Blundell-Bond system GMM estimation, both with the timing assumption. In addition to country and time fixed effects, each specification includes the lagged dependent variable, real output growth (lag), and domestic interest rates (lag). Each macroprudential policy indicator is the average over the previous four quarters and is considered individually. Period sample: 1991Q1 - 2016Q4. AE = advanced economies; and EMDE = emerging market and developing economies. P-values of the Arellano-Bond tests for $\operatorname{AR}(1)$ and $A R(2)$ in first differences are reported. Standard errors clustered at the country-level are reported in parentheses. Confidence levels: ${ }^{* *} p<0.01,{ }^{* *} p<0.05,{ }^{*} p<0.1$ 


\section{Appendix VIII Table 5. Baseline: The Effects of Macroprudential Policies on Real Household Credit Growth}

\begin{tabular}{|c|c|c|c|c|c|c|c|c|c|}
\hline \multirow{4}{*}{$\begin{array}{l}\text { Group: } \\
\text { Quantile/OLS: }\end{array}$} & (1) & (2) & (3) & (4) & (5) & (6) & (7) & (8) & (9) \\
\hline & \multicolumn{9}{|c|}{ Depdendent Variable: Real Household Credit (yoy growth) } \\
\hline & \multicolumn{3}{|c|}{ ALL } & \multicolumn{3}{|c|}{$A E$} & \multicolumn{3}{|c|}{ EMDE } \\
\hline & .1 & FE & .9 & .1 & $\mathrm{FE}$ & .9 & .1 & FE & .9 \\
\hline MaPP (All, Sum) & $\begin{array}{l}-0.550^{*} \\
(0.292)\end{array}$ & $\begin{array}{c}-0.842^{* * *} \\
(0.298)\end{array}$ & $\begin{array}{c}-0.843^{* * *} \\
(0.240)\end{array}$ & $\begin{array}{l}-0.0717 \\
(0.501)\end{array}$ & $\begin{array}{l}-0.257 \\
(0.311)\end{array}$ & $\begin{array}{c}-0.620^{* * *} \\
(0.113)\end{array}$ & $\begin{array}{l}-1.376^{*} \\
(0.788)\end{array}$ & $\begin{array}{c}-1.388^{* * *} \\
(0.398)\end{array}$ & $\begin{array}{c}-1.220 * * \\
(0.580)\end{array}$ \\
\hline MaPP (Loan, Sum) & $\begin{array}{l}-1.538 \\
(2.180)\end{array}$ & $\begin{array}{c}-1.883^{* * *} \\
(0.510)\end{array}$ & $\begin{array}{c}-1.458^{* * *} \\
(0.394)\end{array}$ & $\begin{array}{l}-1.145 \\
(1.146)\end{array}$ & $\begin{array}{c}-1.043^{* *} \\
(0.488)\end{array}$ & $\begin{array}{c}-0.834^{* * *} \\
(0.283)\end{array}$ & $\begin{array}{c}-2.702^{* * *} \\
(0.889)\end{array}$ & $\begin{array}{c}-2.925^{\star \star *} \\
(0.888)\end{array}$ & $\begin{array}{l}-2.864^{* *} \\
(1.265)\end{array}$ \\
\hline MaPP (Demand, Sum) & $\begin{array}{l}-1.939^{*} \\
(1.152)\end{array}$ & $\begin{array}{c}-1.994^{* * *} \\
(0.684)\end{array}$ & $\begin{array}{c}-1.320^{* *} \\
(0.599)\end{array}$ & $\begin{array}{l}-0.380 \\
(0.847)\end{array}$ & $\begin{array}{l}-0.607 \\
(0.572)\end{array}$ & $\begin{array}{c}-0.852^{* * *} \\
(0.263)\end{array}$ & $\begin{array}{c}-3.999^{* *} \\
(1.776)\end{array}$ & $\begin{array}{c}-4.926^{\star * *} \\
(1.725)\end{array}$ & $\begin{array}{l}-3.803^{*} \\
(2.181)\end{array}$ \\
\hline MaPP (Supply All, Sum) & $\begin{array}{l}-0.734 \\
(0.756)\end{array}$ & $\begin{array}{l}-0.824^{*} \\
(0.421)\end{array}$ & $\begin{array}{c}-1.034^{* *} \\
(0.421)\end{array}$ & $\begin{array}{c}0.375 \\
(0.427)\end{array}$ & $\begin{array}{c}0.395 \\
(0.518)\end{array}$ & $\begin{array}{l}-0.366 \\
(0.285)\end{array}$ & $\begin{array}{l}-1.728 \\
(1.239)\end{array}$ & $\begin{array}{c}-1.511^{* \star *} \\
(0.528)\end{array}$ & $\begin{array}{l}-1.438 \\
(1.092)\end{array}$ \\
\hline MaPP (Supply Loans, Sum) & $\begin{array}{c}-1.902^{* *} \\
(0.889)\end{array}$ & $\begin{array}{c}-2.931^{* * *} \\
(0.982)\end{array}$ & $\begin{array}{c}-3.010^{* * *} \\
(0.929)\end{array}$ & $\begin{array}{c}-4.564^{* * *} \\
(1.225)\end{array}$ & $\begin{array}{c}-3.028^{* *} \\
(1.231)\end{array}$ & $\begin{array}{l}-1.065 \\
(0.669)\end{array}$ & $\begin{array}{c}-3.243^{\star * *} \\
(1.144)\end{array}$ & $\begin{array}{c}-3.005^{\star *} \\
(1.193)\end{array}$ & $\begin{array}{l}-1.535 \\
(1.308)\end{array}$ \\
\hline MaPP (Supply General, Sum) & $\begin{array}{l}0.0745 \\
(1.267)\end{array}$ & $\begin{array}{l}-0.602 \\
(0.631)\end{array}$ & $\begin{array}{l}-0.297 \\
(0.636)\end{array}$ & $\begin{array}{l}1.246^{* *} \\
(0.496)\end{array}$ & $\begin{array}{c}0.958 \\
(0.593)\end{array}$ & $\begin{array}{c}1.044^{*} \\
(0.570)\end{array}$ & $\begin{array}{l}-1.673^{*} \\
(0.981)\end{array}$ & $\begin{array}{l}-1.354^{*} \\
(0.739)\end{array}$ & $\begin{array}{l}-1.180 \\
(0.829)\end{array}$ \\
\hline MaPP (Supply Capital, Sum) & $\begin{array}{l}-1.239 \\
(1.424)\end{array}$ & $\begin{array}{l}-1.009 \\
(0.673)\end{array}$ & $\begin{array}{l}-1.407 \\
(0.903)\end{array}$ & $\begin{array}{c}0.110 \\
(0.727)\end{array}$ & $\begin{array}{c}0.221 \\
(0.611)\end{array}$ & $\begin{array}{c}-0.980^{* * *} \\
(0.362) \\
\end{array}$ & $\begin{array}{c}-3.329^{\star * *} \\
(1.203)\end{array}$ & $\begin{array}{l}-1.959^{*} \\
(0.969)\end{array}$ & $\begin{array}{l}-3.368 \\
(2.152)\end{array}$ \\
\hline dsti & $\begin{array}{c}-4.485^{\star *} \\
(1.964)\end{array}$ & $\begin{array}{c}-2.648^{* * *} \\
(0.995)\end{array}$ & $\begin{array}{c}-1.713^{* * *} \\
(0.558)\end{array}$ & $\begin{array}{l}-1.133 \\
(1.669)\end{array}$ & $\begin{array}{l}-1.231 \\
(1.034)\end{array}$ & $\begin{array}{c}-1.530^{* * *} \\
(0.393)\end{array}$ & $\begin{array}{c}-5.785^{\star * *} \\
(1.966)\end{array}$ & $\begin{array}{c}-6.173^{* *} \\
(2.589)\end{array}$ & $\begin{array}{l}-1.490 \\
(1.892)\end{array}$ \\
\hline Itv & $\begin{array}{l}-1.840^{*} \\
(1.098)\end{array}$ & $\begin{array}{c}-2.557^{* *} \\
(1.067)\end{array}$ & $\begin{array}{c}-2.057^{* * *} \\
(0.765)\end{array}$ & $\begin{array}{l}-0.800 \\
(0.988)\end{array}$ & $\begin{array}{c}-0.654 \\
(1.041)\end{array}$ & $\begin{array}{l}-0.855^{*} \\
(0.463)\end{array}$ & $\begin{array}{c}-5.763^{\star \star *} \\
(2.212)\end{array}$ & $\begin{array}{c}-5.797^{* * *} \\
(1.734)\end{array}$ & $\begin{array}{l}-5.812 \\
(3.951)\end{array}$ \\
\hline $\operatorname{tax}$ & $\begin{array}{c}-0.206 \\
(1.345)\end{array}$ & $\begin{array}{l}-0.619 \\
(0.988)\end{array}$ & $\begin{array}{c}0.751 \\
(0)\end{array}$ & $\begin{array}{c}-2.253^{* *} \\
(1.083)\end{array}$ & $\begin{array}{l}-1.837 \\
(1.782)\end{array}$ & $\begin{array}{c}-3.764^{\star * *} \\
(0.318)\end{array}$ & $\begin{array}{l}6.214^{*} \\
(3.613)\end{array}$ & $\begin{array}{c}0.351 \\
(0.972)\end{array}$ & $\begin{array}{c}11.92 \\
(9.060)\end{array}$ \\
\hline $\operatorname{lcg}$ & $\begin{array}{c}-3.572 \\
(29.78)\end{array}$ & $\begin{array}{l}-4.620 \\
(3.252)\end{array}$ & $\begin{array}{c}-12.39^{* * *} \\
(3.931)\end{array}$ & $\begin{array}{c}-4.818 \\
(0)\end{array}$ & $\begin{array}{l}-2.142 \\
(1.420)\end{array}$ & $\begin{array}{c}2.301 \\
(0)\end{array}$ & $\begin{array}{c}-6.620^{\star * *} \\
(1.444)\end{array}$ & $\begin{array}{l}-6.562^{*} \\
(3.642)\end{array}$ & $\begin{array}{l}-4.101 \\
(3.285)\end{array}$ \\
\hline$\| p$ & $\begin{array}{l}-4.022^{*} \\
(2.280)\end{array}$ & $\begin{array}{c}-5.865^{\star * *} \\
(2.052)\end{array}$ & $\begin{array}{c}-5.730^{* *} \\
(2.319)\end{array}$ & $\begin{array}{l}-7.673 \\
(5.325)\end{array}$ & $\begin{array}{l}-4.161 \\
(2.691)\end{array}$ & $\begin{array}{l}-0.786 \\
(2.134)\end{array}$ & $\begin{array}{l}-4.642 \\
(2.912)\end{array}$ & $\begin{array}{c}-6.656^{\star \star *} \\
(2.384)\end{array}$ & $\begin{array}{l}-2.699 \\
(4.477)\end{array}$ \\
\hline loanr & $\begin{array}{l}-4.509 \\
(2.841)\end{array}$ & $\begin{array}{c}-3.489^{* *} \\
(1.461)\end{array}$ & $\begin{array}{c}1.334 \\
(4.398)\end{array}$ & $\begin{array}{l}-2.065 \\
(1.848)\end{array}$ & $\begin{array}{c}-4.592^{* *} \\
(1.935)\end{array}$ & $\begin{array}{l}-1.379^{*} \\
(0.815)\end{array}$ & $\begin{array}{l}-3.165 \\
(4.131)\end{array}$ & $\begin{array}{l}-2.885 \\
(2.148)\end{array}$ & $\begin{array}{c}3.890 \\
(8.942)\end{array}$ \\
\hline capital & $\begin{array}{c}-1.642 \\
(1.134) \\
\end{array}$ & $\begin{array}{l}-1.091 \\
(0.905) \\
\end{array}$ & $\begin{array}{c}-2.358^{* *} \\
(0.940) \\
\end{array}$ & $\begin{array}{l}-0.146 \\
(1.348) \\
\end{array}$ & $\begin{array}{l}0.0547 \\
(0.874) \\
\end{array}$ & $\begin{array}{c}-0.985^{* * *} \\
(0.377) \\
\end{array}$ & $\begin{array}{l}-2.173 \\
(2.299) \\
\end{array}$ & $\begin{array}{l}-1.803 \\
(1.244) \\
\end{array}$ & $\begin{array}{c}-5.523^{\star * *} \\
(2.054)\end{array}$ \\
\hline Observations & 4,492 & 4,492 & 4,492 & 2,858 & 2,858 & 2,858 & 1,634 & 1,634 & 1,634 \\
\hline Number of groups & 63 & 63 & 63 & 34 & 34 & 34 & 29 & 29 & 29 \\
\hline R-squared (avg) & & 0.905 & & & 0.890 & & & 0.916 & \\
\hline
\end{tabular}

Sources: The iMaPP database, Bloomberg, BIS, OECD, others (see Appendix IV), and the authors' estimation.

Notes: The table reports the cumulative effects of the specified macroprudential tightening after four quarters, obtained by the fixed effects (FE) estimation with the timing assumption. In addition to country and time fixed effects, each specification includes the lagged dependent variable, real output growth (lag), and domestic interest rates (lag). Each macroprudential policy indicator is the average over the previous four quarters and is considered individually. Quantile regressions refer to $10^{\text {th }}$ and $90^{\text {th }}$ percentile, respectively. Period sample: $1991 \mathrm{Q} 1-2016 \mathrm{Q} 4$. AE = advanced economies; and EMDE $=$ emerging market and developing economies. Standard errors clustered at the country-level are reported in parentheses. Confidence levels: ${ }^{* * *}$ $p<0.01,{ }^{* *} p<0.05,{ }^{*} p<0.1$ 


\section{Appendix VIII Table 6. Baseline: The Effects of Macroprudential Policies on Real Private Consumption Growth}

\begin{tabular}{|c|c|c|c|c|c|c|c|c|c|}
\hline \multirow{4}{*}{$\begin{array}{l}\text { Group: } \\
\text { Quantile/OLS: }\end{array}$} & (1) & (2) & (3) & (4) & (5) & (6) & (7) & (8) & (9) \\
\hline & \multicolumn{9}{|c|}{ Depdendent Variable: Real Consumption (yoy growth) } \\
\hline & \multicolumn{3}{|c|}{ ALL } & \multicolumn{3}{|c|}{$\mathrm{AE}$} & \multicolumn{3}{|c|}{ EMDE } \\
\hline & .1 & $\mathrm{FE}$ & .9 & .1 & $\mathrm{FE}$ & .9 & .1 & $\mathrm{FE}$ & .9 \\
\hline MaPP (All, Sum) & $\begin{array}{l}-0.139 \\
(0.286)\end{array}$ & $\begin{array}{l}-0.150 \\
(0.152)\end{array}$ & $\begin{array}{c}-0.197 \\
(0.283)\end{array}$ & $\begin{array}{l}0.0459 \\
(0.322)\end{array}$ & $\begin{array}{c}-0.170 \\
(0.135)\end{array}$ & $\begin{array}{c}-0.401 \\
(0.277)\end{array}$ & $\begin{array}{l}-0.666^{*} \\
(0.394)\end{array}$ & $\begin{array}{c}-0.197 \\
(0.240)\end{array}$ & $\begin{array}{c}-0.361 \\
(0.333)\end{array}$ \\
\hline MaPP (Loan, Sum) & $\begin{array}{c}-0.861 \\
(0.561)\end{array}$ & $\begin{array}{c}-0.999^{* * *} \\
(0.310)\end{array}$ & $\begin{array}{l}-0.983^{*} \\
(0.529)\end{array}$ & $\begin{array}{c}-0.516 \\
(0.528)\end{array}$ & $\begin{array}{c}-0.888^{* *} \\
(0.325)\end{array}$ & $\begin{array}{c}-0.758^{* * *} \\
(0.283)\end{array}$ & $\begin{array}{c}-1.245^{\star * *} \\
(0.335)\end{array}$ & $\begin{array}{c}-0.914 \\
(0.542)\end{array}$ & $\begin{array}{c}-0.958 \\
(0.683)\end{array}$ \\
\hline MaPP (Demand, Sum) & $\begin{array}{l}-0.838 \\
(8.090)\end{array}$ & $\begin{array}{l}-0.649^{*} \\
(0.344)\end{array}$ & $\begin{array}{l}-0.618^{*} \\
(0.357)\end{array}$ & $\begin{array}{c}-0.224 \\
(0.633)\end{array}$ & $\begin{array}{l}-0.527^{*} \\
(0.268)\end{array}$ & $\begin{array}{l}-0.767^{*} \\
(0.416)\end{array}$ & $\begin{array}{l}-1.744 \\
(1.544)\end{array}$ & $\begin{array}{l}-0.607 \\
(0.965)\end{array}$ & $\begin{array}{c}-0.468 \\
(1.455)\end{array}$ \\
\hline MaPP (Supply All, Sum) & $\begin{array}{c}0.205 \\
(0.357)\end{array}$ & $\begin{array}{l}0.0964 \\
(0.226)\end{array}$ & $\begin{array}{c}0.502^{*} \\
(0.297)\end{array}$ & $\begin{array}{c}0.557 \\
(0.469)\end{array}$ & $\begin{array}{c}0.476 \\
(0.352)\end{array}$ & $\begin{array}{l}0.0524 \\
(0.392)\end{array}$ & $\begin{array}{l}-0.461 \\
(0.556)\end{array}$ & $\begin{array}{c}-0.176 \\
(0.289)\end{array}$ & $\begin{array}{c}-0.209 \\
(1.259)\end{array}$ \\
\hline MaPP (Supply Loans, Sum) & $\begin{array}{l}-1.491 \\
(0.996)\end{array}$ & $\begin{array}{c}-2.006^{* *} \\
(0.765)\end{array}$ & $\begin{array}{c}-2.016^{\star * *} \\
(0.731)\end{array}$ & $\begin{array}{c}-1.319 \\
(0.928)\end{array}$ & $\begin{array}{c}-2.707^{* *} \\
(1.048)\end{array}$ & $\begin{array}{l}-2.134 \\
(1.664)\end{array}$ & $\begin{array}{l}-1.769 \\
(1.083)\end{array}$ & $\begin{array}{l}-1.370 \\
(0.929)\end{array}$ & $\begin{array}{l}-1.054 \\
(1.360)\end{array}$ \\
\hline MaPP (Supply General, Sum) & $\begin{array}{c}0.962 \\
(0.765)\end{array}$ & $\begin{array}{c}0.359 \\
(0.309)\end{array}$ & $\begin{array}{c}0.472 \\
(0.491)\end{array}$ & $\begin{array}{c}2.002^{* * *} \\
(0.503)\end{array}$ & $\begin{array}{c}0.998^{*} \\
(0.494)\end{array}$ & $\begin{array}{c}1.136 \\
(0.742)\end{array}$ & $\begin{array}{c}-0.00939 \\
(3.044)\end{array}$ & $\begin{array}{c}0.0276 \\
(0.411)\end{array}$ & $\begin{array}{c}-0.649 \\
(1.150)\end{array}$ \\
\hline MaPP (Supply Capital, Sum) & $\begin{array}{l}-0.504 \\
(0.767)\end{array}$ & $\begin{array}{l}-0.137 \\
(0.456)\end{array}$ & $\begin{array}{c}0.685 \\
(0.750)\end{array}$ & $\begin{array}{c}-0.0986 \\
(0.792)\end{array}$ & $\begin{array}{r}-0.0225 \\
(0.647)\end{array}$ & $\begin{array}{l}-0.433 \\
(0.387)\end{array}$ & $\begin{array}{l}-1.266 \\
(1.277)\end{array}$ & $\begin{array}{c}-0.453 \\
(0.739)\end{array}$ & $\begin{array}{c}0.207 \\
(1.311)\end{array}$ \\
\hline dsti & $\begin{array}{c}-0.262 \\
(1.434)\end{array}$ & $\begin{array}{c}-1.054 \\
(1.127)\end{array}$ & $\begin{array}{c}-1.603 \\
(1.043)\end{array}$ & $\begin{array}{c}-0.500 \\
(2.105)\end{array}$ & $\begin{array}{c}-1.066 \\
(0.978)\end{array}$ & $\begin{array}{c}-0.589 \\
(0.760)\end{array}$ & $\begin{array}{l}-1.801 \\
(4.112)\end{array}$ & $\begin{array}{l}-1.569 \\
(2.937)\end{array}$ & $\begin{array}{c}-0.890 \\
(1.253)\end{array}$ \\
\hline Itv & $\begin{array}{l}-1.043 \\
(0.954)\end{array}$ & $\begin{array}{l}-0.778^{*} \\
(0.439)\end{array}$ & $\begin{array}{l}-0.735 \\
(8.713)\end{array}$ & $\begin{array}{c}-0.0824 \\
(0.601)\end{array}$ & $\begin{array}{l}-0.573 \\
(0.384)\end{array}$ & $\begin{array}{c}-1.104^{* *} \\
(0.495)\end{array}$ & $\begin{array}{l}-3.310 \\
(2.031)\end{array}$ & $\begin{array}{l}-0.378 \\
(0.941)\end{array}$ & $\begin{array}{c}-0.528 \\
(1.267)\end{array}$ \\
\hline $\operatorname{tax}$ & $\begin{array}{l}-0.802 \\
(2.144)\end{array}$ & $\begin{array}{c}-1.204 \\
(1.025)\end{array}$ & $\begin{array}{l}-2.537 \\
(2.261)\end{array}$ & $\begin{array}{c}-2.019 \\
(1.643)\end{array}$ & $\begin{array}{l}-1.940 \\
(1.415)\end{array}$ & $\begin{array}{c}0.915 \\
(7.176)\end{array}$ & $\begin{array}{c}4.473 \\
(3.466)\end{array}$ & $\begin{array}{c}-0.661 \\
(0.601)\end{array}$ & $\begin{array}{c}-4.154 \\
(6.041)\end{array}$ \\
\hline $\operatorname{lcg}$ & $\begin{array}{c}1.219 \\
(1.690)\end{array}$ & $\begin{array}{c}0.638 \\
(0.997)\end{array}$ & $\begin{array}{c}3.312 \\
(2.933)\end{array}$ & $\begin{array}{c}3.768^{* * *} \\
(0.826)\end{array}$ & $\begin{array}{c}0.513 \\
(0.556)\end{array}$ & $\begin{array}{c}-5.396^{* * *} \\
(0.301)\end{array}$ & $\begin{array}{c}-2.204 \\
(1.436)\end{array}$ & $\begin{array}{c}0.377 \\
(1.204)\end{array}$ & $\begin{array}{c}0.0573 \\
(1.944)\end{array}$ \\
\hline Ilp & $\begin{array}{l}-1.294^{*} \\
(0.705)\end{array}$ & $\begin{array}{l}-2.153 \\
(1.301)\end{array}$ & $\begin{array}{l}-1.795^{*} \\
(1.071)\end{array}$ & $\begin{array}{l}-1.441 \\
(1.172)\end{array}$ & $\begin{array}{l}-2.193^{*} \\
(1.283)\end{array}$ & $\begin{array}{l}-1.122 \\
(1.644)\end{array}$ & $\begin{array}{l}-2.326 \\
(2.467)\end{array}$ & $\begin{array}{l}-2.176 \\
(1.443)\end{array}$ & $\begin{array}{c}-0.229 \\
(2.967)\end{array}$ \\
\hline loanr & $\begin{array}{c}-3.727^{* *} \\
(1.657)\end{array}$ & $\begin{array}{c}-3.841^{\star \star *} \\
(1.353)\end{array}$ & $\begin{array}{c}-3.956^{\star * *} \\
(0.551)\end{array}$ & $\begin{array}{l}-4.249^{*} \\
(2.536)\end{array}$ & $\begin{array}{c}-4.267^{\star *} \\
(1.619)\end{array}$ & $\begin{array}{c}-2.505^{\star *} \\
(1.135)\end{array}$ & $\begin{array}{l}-1.318 \\
(8.297)\end{array}$ & $\begin{array}{l}-2.486 \\
(2.238)\end{array}$ & $\begin{array}{l}-2.520 \\
(4.001)\end{array}$ \\
\hline capital & $\begin{array}{l}-1.299 \\
(1.031) \\
\end{array}$ & $\begin{array}{r}-0.0605 \\
(0.565) \\
\end{array}$ & $\begin{array}{c}0.979 \\
(0.822) \\
\end{array}$ & $\begin{array}{c}0.134 \\
(0.803) \\
\end{array}$ & $\begin{array}{c}0.175 \\
(0.866) \\
\end{array}$ & $\begin{array}{c}-0.147 \\
(0.624) \\
\end{array}$ & $\begin{array}{l}-2.328^{*} \\
(1.400)\end{array}$ & $\begin{array}{c}-0.318 \\
(0.842) \\
\end{array}$ & $\begin{array}{r}1.989 \\
(1.354) \\
\end{array}$ \\
\hline Observations & 4,639 & 4,639 & 4,639 & 2,863 & 2,863 & 2,863 & 1,776 & 1,776 & 1,776 \\
\hline Number of groups & 55 & 55 & 55 & 31 & 31 & 31 & 24 & 24 & 24 \\
\hline R-squared (avg) & & 0.816 & & & 0.788 & & & 0.824 & \\
\hline
\end{tabular}

Sources: The iMaPP database, Bloomberg, BIS, OECD, others (see Appendix IV), and the authors' estimation.

Notes: The table reports the cumulative effects of the specified macroprudential tightening after four quarters, obtained by the fixed effects (FE) estimation with the timing assumption. In addition to country and time fixed effects, each specification includes the lagged dependent variable, real output growth (lag), and domestic interest rates (lag). Each macroprudential policy indicator is the average over the previous four quarters and is considered individually. Quantile regressions refer to $10^{\text {th }}$ and $90^{\text {th }}$ percentile, respectively. Period sample: $1991 \mathrm{Q} 1-2016 \mathrm{Q} 4$. AE = advanced economies; and EMDE $=$ emerging market and developing economies. Standard errors clustered at the country-level are reported in parentheses. Confidence levels: ${ }^{* * *}$ $p<0.01,{ }^{* *} p<0.05,{ }^{*} p<0.1$ 


\section{Appendix VIII Table 7. Baseline: The Effects of Macroprudential Policies on Real House Prices Growth}

\begin{tabular}{|c|c|c|c|c|c|c|c|c|c|}
\hline \multirow{4}{*}{$\begin{array}{l}\text { Group: } \\
\text { Quantile/OLS: }\end{array}$} & (1) & $(2)$ & (3) & $(4)$ & (5) & (6) & (7) & $(8)$ & (9) \\
\hline & \multicolumn{9}{|c|}{ Depdendent Variable: Real House Prices (yoy growth) } \\
\hline & \multicolumn{3}{|c|}{ ALL } & \multicolumn{3}{|c|}{$\mathrm{AE}$} & \multicolumn{3}{|c|}{ EMDE } \\
\hline & .1 & $\mathrm{FE}$ & .9 & .1 & $\mathrm{FE}$ & .9 & .1 & $\mathrm{FE}$ & .9 \\
\hline MaPP (All, Sum) & $\begin{array}{c}-0.713^{*} \\
(0.368)\end{array}$ & $\begin{array}{r}-0.0877 \\
(0.201)\end{array}$ & $\begin{array}{c}-0.234 \\
(0.176)\end{array}$ & $\begin{array}{l}-0.727 \\
(0.466)\end{array}$ & $\begin{array}{c}-0.898^{* *} \\
(0.420)\end{array}$ & $\begin{array}{c}-1.129^{* * *} \\
(0.281)\end{array}$ & $\begin{array}{l}-0.524 \\
(0.556)\end{array}$ & $\begin{array}{l}0.0619 \\
(0.330)\end{array}$ & $\begin{array}{r}-0.0631 \\
(0.274)\end{array}$ \\
\hline MaPP (Loan, Sum) & $\begin{array}{l}-1.154 \\
(0.751)\end{array}$ & $\begin{array}{c}-1.066^{\star *} \\
(0.482)\end{array}$ & $\begin{array}{l}-0.509 \\
(0.418)\end{array}$ & $\begin{array}{l}-1.161 \\
(0.731)\end{array}$ & $\begin{array}{c}-1.667^{\star *} \\
(0.757)\end{array}$ & $\begin{array}{c}-1.374^{* *} \\
(0.582)\end{array}$ & $\begin{array}{l}-1.042 \\
(0.660)\end{array}$ & $\begin{array}{l}-0.615 \\
(0.765)\end{array}$ & $\begin{array}{c}-0.566^{* *} \\
(0.257)\end{array}$ \\
\hline MaPP (Demand, Sum) & $\begin{array}{l}-0.637 \\
(0.745)\end{array}$ & $\begin{array}{c}-1.406^{* *} \\
(0.630)\end{array}$ & $\begin{array}{l}-0.768 \\
(0.964)\end{array}$ & $\begin{array}{c}-1.332^{* * *} \\
(0.515)\end{array}$ & $\begin{array}{c}-2.049^{* *} \\
(0.827)\end{array}$ & $\begin{array}{l}-1.402 \\
(0.933)\end{array}$ & $\begin{array}{c}0.00370 \\
(1.655)\end{array}$ & $\begin{array}{l}-0.213 \\
(1.509)\end{array}$ & $\begin{array}{c}-0.274 \\
(1.204)\end{array}$ \\
\hline MaPP (Supply All, Sum) & $\begin{array}{l}-0.588 \\
(0.819)\end{array}$ & $\begin{array}{c}0.253 \\
(0.295)\end{array}$ & $\begin{array}{c}-0.00772 \\
(0.728)\end{array}$ & $\begin{array}{l}-0.364 \\
(1.031)\end{array}$ & $\begin{array}{l}0.0116 \\
(0.477)\end{array}$ & $\begin{array}{l}-1.010^{*} \\
(0.576)\end{array}$ & $\begin{array}{l}-0.717 \\
(0.630)\end{array}$ & $\begin{array}{c}0.00789 \\
(0.359)\end{array}$ & $\begin{array}{l}0.0208 \\
(0.654)\end{array}$ \\
\hline MaPP (Supply Loans, Sum) & $\begin{array}{l}-2.511^{*} \\
(1.372)\end{array}$ & $\begin{array}{l}-1.191 \\
(0.779)\end{array}$ & $\begin{array}{c}-0.0899 \\
(1.259)\end{array}$ & $\begin{array}{l}-2.677 \\
(2.006)\end{array}$ & $\begin{array}{l}-1.970 \\
(1.250)\end{array}$ & $\begin{array}{l}-1.634^{*} \\
(0.838)\end{array}$ & $\begin{array}{c}-1.719 * * * \\
(0.546)\end{array}$ & $\begin{array}{l}-1.191 \\
(0.898)\end{array}$ & $\begin{array}{c}1.010 \\
(1.893)\end{array}$ \\
\hline MaPP (Supply General, Sum) & $\begin{array}{l}-0.492 \\
(0.743)\end{array}$ & $\begin{array}{c}0.485 \\
(0.402)\end{array}$ & $\begin{array}{c}0.626 \\
(0.867)\end{array}$ & $\begin{array}{l}-0.820 \\
(1.310)\end{array}$ & $\begin{array}{l}0.0313 \\
(0.549)\end{array}$ & $\begin{array}{c}0.128 \\
(0.562)\end{array}$ & $\begin{array}{l}-0.549 \\
(1.059)\end{array}$ & $\begin{array}{c}0.175 \\
(0.533)\end{array}$ & $\begin{array}{c}0.572 \\
(1.230)\end{array}$ \\
\hline MaPP (Supply Capital, Sum) & $\begin{array}{r}-0.0375 \\
(0.951) \\
\end{array}$ & $\begin{array}{c}0.270 \\
(0.711)\end{array}$ & $\begin{array}{l}-1.093 \\
(0.847)\end{array}$ & $\begin{array}{c}0.303 \\
(1.178)\end{array}$ & $\begin{array}{l}0.0689 \\
(1.199)\end{array}$ & $\begin{array}{l}-1.784 \\
(1.794)\end{array}$ & $\begin{array}{c}0.775 \\
(1.389)\end{array}$ & $\begin{array}{c}0.459 \\
(0.924)\end{array}$ & $\begin{array}{c}1.250 \\
(1.561)\end{array}$ \\
\hline dsti & $\begin{array}{c}0.278 \\
(1.049)\end{array}$ & $\begin{array}{l}-1.455 \\
(1.693)\end{array}$ & $\begin{array}{l}-1.498 \\
(3.034)\end{array}$ & $\begin{array}{l}-1.664 \\
(1.295)\end{array}$ & $\begin{array}{l}-3.167 \\
(2.594)\end{array}$ & $\begin{array}{l}-0.942 \\
(2.610)\end{array}$ & $\begin{array}{c}4.891 \\
(2.988)\end{array}$ & $\begin{array}{c}2.537 \\
(2.304)\end{array}$ & $\begin{array}{c}3.329^{*} \\
(1.870)\end{array}$ \\
\hline Itv & $\begin{array}{l}-2.243 \\
(1.400)\end{array}$ & $\begin{array}{c}-1.952^{* * *} \\
(0.713)\end{array}$ & $\begin{array}{c}-0.491 \\
(0.831)\end{array}$ & $\begin{array}{c}-2.872^{* * *} \\
(0.984)\end{array}$ & $\begin{array}{c}-2.627^{* * *} \\
(0.636)\end{array}$ & $\begin{array}{l}-1.817 \\
(1.377)\end{array}$ & $\begin{array}{l}-1.480 \\
(2.702)\end{array}$ & $\begin{array}{l}-1.020 \\
(1.972)\end{array}$ & $\begin{array}{l}-1.487 \\
(0.924)\end{array}$ \\
\hline $\operatorname{tax}$ & $\begin{array}{l}-3.809 \\
(6.667)\end{array}$ & $\begin{array}{l}-0.680 \\
(2.649)\end{array}$ & $\begin{array}{l}-4.320^{*} \\
(2.276)\end{array}$ & $\begin{array}{l}-8.465 \\
(14.77)\end{array}$ & $\begin{array}{c}-6.479^{\star * *} \\
(2.274)\end{array}$ & $\begin{array}{c}-7.237^{\star * *} \\
(1.465)\end{array}$ & $\begin{array}{l}7.609^{* *} \\
(3.832)\end{array}$ & $\begin{array}{c}4.372^{*} \\
(2.167)\end{array}$ & $\begin{array}{c}2.927 \\
(2.952)\end{array}$ \\
\hline $\operatorname{lcg}$ & $\begin{array}{l}-3.882 \\
(3.607)\end{array}$ & $\begin{array}{l}-1.965 \\
(2.329)\end{array}$ & $\begin{array}{l}-1.657 \\
(6.231)\end{array}$ & $\begin{array}{c}7.433^{* * *} \\
(1.247)\end{array}$ & $\begin{array}{c}-0.0586 \\
(0.764)\end{array}$ & $\begin{array}{c}0.0987 \\
(0)\end{array}$ & $\begin{array}{l}-4.249 \\
(8.567)\end{array}$ & $\begin{array}{l}-2.436 \\
(2.303)\end{array}$ & $\begin{array}{c}-0.871 \\
(2.946)\end{array}$ \\
\hline IIp & $\begin{array}{c}-1.538^{*} \\
(0.835)\end{array}$ & $\begin{array}{c}-2.987^{\star *} \\
(1.199)\end{array}$ & $\begin{array}{l}-1.629 \\
(2.037)\end{array}$ & $\begin{array}{l}-0.392 \\
(1.389)\end{array}$ & $\begin{array}{l}-1.510 \\
(1.152)\end{array}$ & $\begin{array}{c}-2.124 \\
(8.577)\end{array}$ & $\begin{array}{c}-3.289^{* *} \\
(1.316)\end{array}$ & $\begin{array}{c}-4.529^{\star *} \\
(1.954)\end{array}$ & $\begin{array}{c}-4.618^{* * *} \\
(1.396)\end{array}$ \\
\hline loanr & $\begin{array}{c}-4.538^{\star * *} \\
(1.613)\end{array}$ & $\begin{array}{l}-1.385 \\
(1.552)\end{array}$ & $\begin{array}{c}0.166 \\
(2.326)\end{array}$ & $\begin{array}{c}-7.895^{* * *} \\
(2.890)\end{array}$ & $\begin{array}{l}-4.164^{*} \\
(2.222)\end{array}$ & $\begin{array}{l}-1.756 \\
(3.310)\end{array}$ & $\begin{array}{c}-3.352^{\star *} \\
(1.466)\end{array}$ & $\begin{array}{c}-0.262 \\
(2.266)\end{array}$ & $\begin{array}{c}2.963 \\
(4.392)\end{array}$ \\
\hline capital & $\begin{array}{l}-0.652 \\
(1.141)\end{array}$ & $\begin{array}{c}0.304 \\
(0.904)\end{array}$ & $\begin{array}{l}-1.056 \\
(1.005)\end{array}$ & $\begin{array}{c}-0.371 \\
(1.649)\end{array}$ & $\begin{array}{l}-0.157 \\
(1.510)\end{array}$ & $\begin{array}{l}-1.774 \\
(1.319)\end{array}$ & $\begin{array}{c}0.450 \\
(1.306)\end{array}$ & $\begin{array}{c}0.582 \\
(1.102)\end{array}$ & $\begin{array}{l}-1.632 \\
(2.405)\end{array}$ \\
\hline Observations & 4,111 & 4,111 & 4,111 & 2,780 & 2,780 & 2,780 & 1,331 & 1,331 & 1,331 \\
\hline Number of groups & 55 & 55 & 55 & 34 & 34 & 34 & 21 & 21 & 21 \\
\hline R-squared (avg) & & 0.823 & & & 0.855 & & & 0.800 & \\
\hline
\end{tabular}

Sources: The iMaPP database, Bloomberg, BIS, OECD, others (see Appendix IV), and the authors' estimation.

Notes: The table reports the cumulative effects of the specified macroprudential tightening after four quarters, obtained by the fixed effects (FE) estimation with the timing assumption. In addition to country and time fixed effects, each specification includes the lagged dependent variable, real output growth (lag), and domestic interest rates (lag). Each macroprudential policy indicator is the average over the previous four quarters and is considered individually. Quantile regressions refer to $10^{\text {th }}$ and $90^{\text {th }}$ percentile, respectively. Period sample: $1991 \mathrm{Q} 1-2016 \mathrm{Q} 4$. AE = advanced economies; and EMDE $=$ emerging market and developing economies. Standard errors clustered at the country-level are reported in parentheses. Confidence levels: ${ }^{* * *}$ $p<0.01,{ }^{* *} p<0.05,{ }^{*} p<0.1$ 


\section{Appendix VIII Table 8. Baseline: The Effects of Macroprudential Policies on Real GDP Growth}

\begin{tabular}{|c|c|c|c|c|c|c|c|c|c|}
\hline \multirow{4}{*}{$\begin{array}{l}\text { Group: } \\
\text { Quantile/OLS: }\end{array}$} & (1) & $(2)$ & (3) & (4) & (5) & (6) & (7) & (8) & (9) \\
\hline & \multicolumn{9}{|c|}{ Depdendent Variable: Real GDP (yoy growth) } \\
\hline & \multicolumn{3}{|c|}{ ALL } & \multicolumn{3}{|c|}{$\mathrm{AE}$} & \multicolumn{3}{|c|}{ EMDE } \\
\hline & .1 & FE & .9 & .1 & FE & .9 & .1 & $\mathrm{FE}$ & .9 \\
\hline MaPP (All, Sum) & $\begin{array}{c}0.0651 \\
(0.0620)\end{array}$ & $\begin{array}{c}0.0466 \\
(0.0562)\end{array}$ & $\begin{array}{l}-0.0158 \\
(0.0483)\end{array}$ & $\begin{array}{l}0.0289 \\
(0.102)\end{array}$ & $\begin{array}{l}-0.0414 \\
(0.0660)\end{array}$ & $\begin{array}{l}-0.147^{\star \star} \\
(0.0746)\end{array}$ & $\begin{array}{c}-0.0670 \\
(0.203)\end{array}$ & $\begin{array}{c}0.0427 \\
(0.0762)\end{array}$ & $\begin{array}{l}-0.0179 \\
(0.0617)\end{array}$ \\
\hline MaPP (Loan, Sum) & $\begin{array}{r}-0.0143 \\
(0.123)\end{array}$ & $\begin{array}{l}-0.0729 \\
(0.120)\end{array}$ & $\begin{array}{l}-0.132 \\
(0.195)\end{array}$ & $\begin{array}{r}-0.0580 \\
(0.181)\end{array}$ & $\begin{array}{l}-0.119 \\
(0.147)\end{array}$ & $\begin{array}{l}-0.255^{\star \star} \\
(0.120)\end{array}$ & $\begin{array}{l}0.0830 \\
(0.112)\end{array}$ & $\begin{array}{l}-0.0582 \\
(0.178)\end{array}$ & $\begin{array}{l}-0.147 \\
(0.111)\end{array}$ \\
\hline MaPP (Demand, Sum) & $\begin{array}{c}-0.0903 \\
(0.205)\end{array}$ & $\begin{array}{l}-0.112 \\
(0.121)\end{array}$ & $\begin{array}{c}-0.254 \\
(0.195)\end{array}$ & $\begin{array}{r}-0.0764 \\
(0.223)\end{array}$ & $\begin{array}{l}-0.131 \\
(0.167)\end{array}$ & $\begin{array}{l}-0.144 \\
(0.216)\end{array}$ & $\begin{array}{l}0.0440 \\
(0.276)\end{array}$ & $\begin{array}{l}-0.138 \\
(0.193)\end{array}$ & $\begin{array}{c}-0.337^{\star \star *} \\
(0.119)\end{array}$ \\
\hline MaPP (Supply All, Sum) & $\begin{array}{c}0.0850 \\
(0.0890)\end{array}$ & $\begin{array}{c}0.0885 \\
(0.0831)\end{array}$ & $\begin{array}{l}-0.0178 \\
(0.0664)\end{array}$ & $\begin{array}{l}0.0540 \\
(0.182)\end{array}$ & $\begin{array}{l}-0.0131 \\
(0.164)\end{array}$ & $\begin{array}{l}-0.192 \\
(0.157)\end{array}$ & $\begin{array}{l}-0.102 \\
(0.265)\end{array}$ & $\begin{array}{c}0.0737 \\
(0.0995)\end{array}$ & $\begin{array}{c}0.0161 \\
(0.0870)\end{array}$ \\
\hline MaPP (Supply Loans, Sum) & $\begin{array}{c}0.138 \\
(0.168)\end{array}$ & $\begin{array}{c}-0.0633 \\
(0.245)\end{array}$ & $\begin{array}{l}-0.362 \\
(0.223)\end{array}$ & $\begin{array}{l}-0.142 \\
(0.338)\end{array}$ & $\begin{array}{l}-0.179 \\
(0.354)\end{array}$ & $\begin{array}{l}-0.835^{\star} \\
(0.431)\end{array}$ & $\begin{array}{c}0.116 \\
(0.180)\end{array}$ & $\begin{array}{l}-0.0301 \\
(0.303)\end{array}$ & $\begin{array}{l}-0.188 \\
(0.262)\end{array}$ \\
\hline MaPP (Supply General, Sum) & $\begin{array}{c}0.204 \\
(0.133)\end{array}$ & $\begin{array}{c}0.164 \\
(0.124)\end{array}$ & $\begin{array}{c}0.0675 \\
(0.0838)\end{array}$ & $\begin{array}{l}0.0573 \\
(0.362)\end{array}$ & $\begin{array}{l}-0.0314 \\
(0.247)\end{array}$ & $\begin{array}{c}-0.0166 \\
(0.179)\end{array}$ & $\begin{array}{l}0.0815 \\
(0.280)\end{array}$ & $\begin{array}{c}0.163 \\
(0.153)\end{array}$ & $\begin{array}{c}0.241 \\
(0.207)\end{array}$ \\
\hline MaPP (Supply Capital, Sum) & $\begin{array}{l}-0.292 \\
(0.334)\end{array}$ & $\begin{array}{l}-0.118 \\
(0.179)\end{array}$ & $\begin{array}{l}-0.0669 \\
(0.261) \\
\end{array}$ & $\begin{array}{l}0.0937 \\
(0.311)\end{array}$ & $\begin{array}{c}0.103 \\
(0.275) \\
\end{array}$ & $\begin{array}{c}-0.439^{\star \star \star} \\
(0.126) \\
\end{array}$ & $\begin{array}{c}-0.826^{\star *} \\
(0.343)\end{array}$ & $\begin{array}{l}-0.360 \\
(0.232)\end{array}$ & $\begin{array}{l}-0.0104 \\
(0.301)\end{array}$ \\
\hline dsti & $\begin{array}{l}-0.175 \\
(0.553)\end{array}$ & $\begin{array}{l}-0.191 \\
(0.345)\end{array}$ & $\begin{array}{c}0.197 \\
(0.474)\end{array}$ & $\begin{array}{c}-0.0514 \\
(0.461)\end{array}$ & $\begin{array}{l}-0.207 \\
(0.535)\end{array}$ & $\begin{array}{l}0.826^{\star *} \\
(0.417)\end{array}$ & $\begin{array}{c}0.775 \\
(0.474)\end{array}$ & $\begin{array}{l}-0.134 \\
(0.278)\end{array}$ & $\begin{array}{c}-1.122^{\star \star \star} \\
(0.384)\end{array}$ \\
\hline Itv & $\begin{array}{l}-0.125 \\
(0.295)\end{array}$ & $\begin{array}{l}-0.127 \\
(0.156)\end{array}$ & $\begin{array}{l}-0.379^{*} \\
(0.197)\end{array}$ & $\begin{array}{r}-0.0106 \\
(0.483)\end{array}$ & $\begin{array}{l}-0.163 \\
(0.173)\end{array}$ & $\begin{array}{c}-0.445^{\star *} \\
(0.204)\end{array}$ & $\begin{array}{r}-0.0392 \\
(0.317)\end{array}$ & $\begin{array}{l}-0.176 \\
(0.283)\end{array}$ & $\begin{array}{l}-0.222 \\
(0.226)\end{array}$ \\
\hline $\operatorname{tax}$ & $\begin{array}{l}-0.746 \\
(0.550)\end{array}$ & $\begin{array}{l}-0.298 \\
(0.399)\end{array}$ & $\begin{array}{l}-0.463 \\
(0.737)\end{array}$ & $\begin{array}{l}-1.119 \\
(0.730)\end{array}$ & $\begin{array}{l}-0.888^{*} \\
(0.509)\end{array}$ & $\begin{array}{l}-0.908^{*} \\
(0.509)\end{array}$ & $\begin{array}{c}0.523 \\
(2.476)\end{array}$ & $\begin{array}{c}0.297 \\
(0.546)\end{array}$ & $\begin{array}{l}1.141^{\star *} \\
(0.576)\end{array}$ \\
\hline $\operatorname{lcg}$ & $\begin{array}{c}0.122 \\
(0.299)\end{array}$ & $\begin{array}{c}0.197 \\
(0.699)\end{array}$ & $\begin{array}{l}0.0124 \\
(2.206)\end{array}$ & $\begin{array}{c}-1.583 \\
(0)\end{array}$ & $\begin{array}{c}-0.800^{\star *} \\
(0.329)\end{array}$ & $\begin{array}{c}-1.745 \\
(0)\end{array}$ & $\begin{array}{c}-0.0310 \\
(0.547)\end{array}$ & $\begin{array}{c}0.513 \\
(0.658)\end{array}$ & $\begin{array}{c}1.432 \\
(1.131)\end{array}$ \\
\hline$\| p$ & $\begin{array}{l}-0.125 \\
(0.668)\end{array}$ & $\begin{array}{l}-0.482 \\
(0.294)\end{array}$ & $\begin{array}{l}-0.781^{* * *} \\
(0.219)\end{array}$ & $\begin{array}{l}-0.436 \\
(2.826)\end{array}$ & $\begin{array}{l}-0.614 \\
(0.439)\end{array}$ & $\begin{array}{l}-1.284 \\
(2.084)\end{array}$ & $\begin{array}{l}0.604^{*} \\
(0.318)\end{array}$ & $\begin{array}{l}-0.482 \\
(0.330)\end{array}$ & $\begin{array}{l}-0.466 \\
(0.452)\end{array}$ \\
\hline loanr & $\begin{array}{l}0.0964 \\
(0.301)\end{array}$ & $\begin{array}{l}0.00843 \\
(0.448)\end{array}$ & $\begin{array}{l}-0.285 \\
(0.248)\end{array}$ & $\begin{array}{r}-0.0691 \\
(0.794)\end{array}$ & $\begin{array}{l}-0.0258 \\
(0.651)\end{array}$ & $\begin{array}{l}-0.866 \\
(0.701)\end{array}$ & $\begin{array}{c}0.149 \\
(0.469)\end{array}$ & $\begin{array}{l}-0.0511 \\
(0.575)\end{array}$ & $\begin{array}{l}-0.175 \\
(0.227)\end{array}$ \\
\hline capital & $\begin{array}{l}-0.155 \\
(0.391) \\
\end{array}$ & $\begin{array}{l}0.0150 \\
(0.222)\end{array}$ & $\begin{array}{c}-0.00611 \\
(0.298) \\
\end{array}$ & $\begin{array}{c}0.110 \\
(0.408)\end{array}$ & $\begin{array}{c}0.162 \\
(0.395) \\
\end{array}$ & $\begin{array}{c}-0.258 \\
(0.233) \\
\end{array}$ & $\begin{array}{c}-0.567^{\star *} \\
(0.258)\end{array}$ & $\begin{array}{l}-0.147 \\
(0.266)\end{array}$ & $\begin{array}{c}-0.0115 \\
(0.247)\end{array}$ \\
\hline Observations & 5,416 & 5,416 & 5,416 & 3,125 & 3,125 & 3,125 & 2,291 & 2,291 & 2,291 \\
\hline $\begin{array}{l}\text { Number of groups } \\
\text { R-squared (avg) }\end{array}$ & 64 & $\begin{array}{c}64 \\
0.932\end{array}$ & 64 & 34 & $\begin{array}{c}34 \\
0.943\end{array}$ & 34 & 30 & $\begin{array}{c}30 \\
0.920\end{array}$ & 30 \\
\hline
\end{tabular}

Sources: The iMaPP database, Bloomberg, BIS, OECD, others (see Appendix IV), and the authors' estimation.

Notes: The table reports the cumulative effects of the specified macroprudential tightening after four quarters, obtained by the fixed effects (FE) estimation with the timing assumption. In addition to country and time fixed effects, each specification includes the lagged dependent variable and domestic interest rates (lag). Each macroprudential policy indicator is the average over the previous four quarters and is considered individually. Quantile regressions refer to $10^{\text {th }}$ and $90^{\text {th }}$ percentile, respectively. Period sample: 1991Q1 - 2016Q4. AE = advanced economies; and EMDE = emerging market and developing economies. Standard errors clustered at the country-level are reported in parentheses. Confidence levels: ${ }^{* *} p<0.01,{ }^{* *} p<0.05,{ }^{*} p<0.1$. 


\section{Appendix VIII Table 9. Baseline: The Effects of $\Delta$ LTV Limits on Real Household Credit Growth}

\begin{tabular}{|c|c|c|c|c|c|c|c|c|c|c|c|c|}
\hline \multirow[b]{3}{*}{ Group } & \multirow[t]{2}{*}{ (1) } & \multirow[t]{2}{*}{$(2)$} & \multirow[t]{2}{*}{ (3) } & $(4)$ & (5) & $(6)$ & (7) & \multirow[t]{2}{*}{$(8)$} & \multirow{2}{*}{$\begin{array}{l}(9) \\
\text { al) }\end{array}$} & \multirow[t]{2}{*}{$(10)$} & \multirow[t]{2}{*}{$(11)$} & \multirow[t]{2}{*}{$(12)$} \\
\hline & & & & & endent Var & iable: Househ & old Credit $(\%$ & & & & & \\
\hline & ALL & $\mathrm{AE}$ & EMDE & ASIA & EUROPE & AMERICAS & $\begin{array}{c}\mathrm{Hi} F X \\
\text { Regime } \\
\text { Flexibility } \\
\end{array}$ & $\begin{array}{l}\text { Hi Capital } \\
\text { Openness }\end{array}$ & $\begin{array}{l}\text { Hi Financial } \\
\text { Development }\end{array}$ & $\begin{array}{l}\text { Hi DTI Low- } \\
\text { Income } \\
\text { Borrowers }\end{array}$ & $\begin{array}{l}\text { Positive } \\
\text { Credit Gap }\end{array}$ & $\begin{array}{c}\text { Positive } \\
\text { Credit Gap \& } \\
\text { EMDE only }\end{array}$ \\
\hline Household credit ( $\%$ change, yoy, real, lag=1q) & $\begin{array}{l}0.890^{* * *} \\
(0.0179)\end{array}$ & $\begin{array}{l}0.885^{* * *} \\
(0.0444)\end{array}$ & $\begin{array}{l}0.895^{* * *} \\
(0.0134)\end{array}$ & $\begin{array}{l}0.836^{* * *} \\
(0.0342)\end{array}$ & $\begin{array}{l}0.910^{* * *} \\
(0.0210)\end{array}$ & $\begin{array}{l}0.820^{* * *} \\
(0.0199)\end{array}$ & $\begin{array}{l}0.886^{* * *} \\
(0.0230)\end{array}$ & $\begin{array}{l}0.907^{* * *} \\
(0.0355)\end{array}$ & $\begin{array}{l}0.835^{* * *} \\
(0.0421)\end{array}$ & $\begin{array}{l}0.967^{* * *} \\
(0.0101)\end{array}$ & $\begin{array}{l}0.842^{* * *} \\
(0.0337)\end{array}$ & $\begin{array}{l}0.855^{* * *} \\
(0.0263)\end{array}$ \\
\hline Short-term interest rate $(\mathrm{lag}=1 \mathrm{q})$ & $\begin{array}{c}-0.0917^{* * *} \\
(0.0207)\end{array}$ & $\begin{array}{l}-0.0992 \\
(0.0783)\end{array}$ & $\begin{array}{l}-0.110^{* * *} \\
(0.0314)\end{array}$ & $\begin{array}{l}-0.371 \\
(0.317)\end{array}$ & $\begin{array}{l}-0.101^{* * *} \\
(0.0155)\end{array}$ & $\begin{array}{l}-0.0577^{*} \\
(0.0264)\end{array}$ & $\begin{array}{l}-0.0902^{* * *} \\
(0.0225)\end{array}$ & $\begin{array}{c}-0.0471^{* * *} \\
(0.0149)\end{array}$ & $\begin{array}{l}-0.137 \\
(0.107)\end{array}$ & $\begin{array}{l}-0.101^{* *} \\
(0.0302)\end{array}$ & $\begin{array}{l}-0.148^{\star *} \\
(0.0587)\end{array}$ & $\begin{array}{l}-0.145^{\star *} \\
(0.0652)\end{array}$ \\
\hline GDP growth (real, lag=1q) & $\begin{array}{l}0.153^{* * *} \\
(0.0529)\end{array}$ & $\begin{array}{l}0.147^{* *} \\
(0.0675)\end{array}$ & $\begin{array}{l}0.181^{* *} \\
(0.0824)\end{array}$ & $\begin{array}{l}0.0614 \\
(0.115)\end{array}$ & $\begin{array}{c}0.0825 \\
(0.0658)\end{array}$ & $\begin{array}{l}0.339^{\star *} \\
(0.0995)\end{array}$ & $\begin{array}{c}0.146^{*} \\
(0.0738)\end{array}$ & $\begin{array}{c}0.0817 \\
(0.0619)\end{array}$ & $\begin{array}{c}0.150^{*} \\
(0.0723)\end{array}$ & $\begin{array}{l}0.0118 \\
(0.0306)\end{array}$ & $\begin{array}{c}0.144^{*} \\
(0.0861)\end{array}$ & $\begin{array}{l}-0.0982 \\
(0.119)\end{array}$ \\
\hline $\begin{array}{l}\text { LTV level (change, lag=1q) } \\
\qquad(-/+=\text { tightening/loosening) }\end{array}$ & $\begin{array}{c}0.0204 \\
(0.0336)\end{array}$ & $\begin{array}{c}0.0347 \\
(0.0309)\end{array}$ & $\begin{array}{c}0.0406 \\
(0.0612)\end{array}$ & $\begin{array}{l}0.0695^{*} \\
(0.0369)\end{array}$ & $\begin{array}{l}-0.0342 \\
(0.0543)\end{array}$ & $\begin{array}{c}0.158^{* *} \\
(0.0471)\end{array}$ & $\begin{array}{l}0.00833 \\
(0.0435)\end{array}$ & $\begin{array}{c}0.0292 \\
(0.0193)\end{array}$ & $\begin{array}{c}0.0592 \\
(0.0364)\end{array}$ & $\begin{array}{c}0.0464 \\
(0.0393)\end{array}$ & $\begin{array}{l}-0.0529 \\
(0.0472)\end{array}$ & $\begin{array}{l}-0.0570 \\
(0.0717)\end{array}$ \\
\hline LTV level (change, lag $=2 q$ ) & $\begin{array}{c}0.0392 \\
(0.0444)\end{array}$ & $\begin{array}{c}-0.0180 \\
(0.0621)\end{array}$ & $\begin{array}{l}0.133^{\star * *} \\
(0.0401)\end{array}$ & $\begin{array}{l}0.0792^{* *} \\
(0.0342)\end{array}$ & $\begin{array}{c}0.0453 \\
(0.0652)\end{array}$ & $\begin{array}{l}0.0346 \\
(0.151)\end{array}$ & $\begin{array}{c}0.0456 \\
(0.0630)\end{array}$ & $\begin{array}{c}0.0148 \\
(0.0200)\end{array}$ & $\begin{array}{c}0.0330 \\
(0.0355)\end{array}$ & $\begin{array}{l}0.0720^{*} \\
(0.0351)\end{array}$ & $\begin{array}{c}0.0468 \\
(0.0481)\end{array}$ & $\begin{array}{l}0.108^{* * *} \\
(0.0356)\end{array}$ \\
\hline LTV level (change, lag=3q) & $\begin{array}{c}0.0522 \\
(0.0347)\end{array}$ & $\begin{array}{c}0.0398 \\
(0.0335)\end{array}$ & $\begin{array}{c}0.106^{* *} \\
(0.0430)\end{array}$ & $\begin{array}{c}0.0881^{* * *} \\
(0.0268)\end{array}$ & $\begin{array}{c}0.0508 \\
(0.0582)\end{array}$ & $\begin{array}{c}0.153 \\
(0.0888)\end{array}$ & $\begin{array}{c}0.0649 \\
(0.0505)\end{array}$ & $\begin{array}{c}0.0319 \\
(0.0240)\end{array}$ & $\begin{array}{c}0.0419 \\
(0.0345)\end{array}$ & $\begin{array}{c}0.0786 \\
(0.0680)\end{array}$ & $\begin{array}{c}0.0682 \\
(0.0625)\end{array}$ & $\begin{array}{c}0.121^{*} \\
(0.0619)\end{array}$ \\
\hline LTV level (change, lag=4q) & $\begin{array}{c}0.0352 \\
(0.0247)\end{array}$ & $\begin{array}{c}0.0133 \\
(0.0216)\end{array}$ & $\begin{array}{c}0.0940^{\star * *} \\
(0.0277)\end{array}$ & $\begin{array}{l}0.0631^{*} \\
(0.0340)\end{array}$ & $\begin{array}{c}0.0239 \\
(0.0313)\end{array}$ & $\begin{array}{c}0.109 \\
(0.164)\end{array}$ & $\begin{array}{c}0.0537 \\
(0.0406)\end{array}$ & $\begin{array}{l}0.00418 \\
(0.0266)\end{array}$ & $\begin{array}{c}0.0343 \\
(0.0309)\end{array}$ & $\begin{array}{c}0.131^{* *} \\
(0.0482)\end{array}$ & $\begin{array}{c}0.0569 \\
(0.0354)\end{array}$ & $\begin{array}{l}0.117^{\star \star *} \\
(0.0288)\end{array}$ \\
\hline Constant & $\begin{array}{l}-1.413 \\
(1.898)\end{array}$ & $\begin{array}{c}1.249 \\
(1.055)\end{array}$ & $\begin{array}{l}-8.069 \\
(6.149)\end{array}$ & $\begin{array}{c}3.212 \\
(2.474)\end{array}$ & $\begin{array}{l}-0.830 \\
(2.510)\end{array}$ & $\begin{array}{l}-5.999 \\
(6.956)\end{array}$ & $\begin{array}{c}-2.835 \\
(3.090)\end{array}$ & $\begin{array}{c}0.995 \\
(0.736)\end{array}$ & $\begin{array}{c}0.799 \\
(0.815)\end{array}$ & $\begin{array}{c}0.249 \\
(0.388)\end{array}$ & $\begin{array}{l}-6.147 \\
(4.273)\end{array}$ & $\begin{array}{l}-20.05^{*} \\
(11.10)\end{array}$ \\
\hline Observations & 3,236 & 2,018 & 1,262 & 674 & 1,883 & 479 & 1,799 & 1,790 & 1,302 & 435 & 1,513 & 526 \\
\hline R-squared & 0.918 & 0.912 & 0.934 & 0.877 & 0.945 & 0.893 & 0.907 & 0.933 & 0.854 & 0.986 & 0.902 & 0.940 \\
\hline Sum coeff LTV level & 0.15 & 0.07 & 0.37 & 0.30 & 0.09 & 0.45 & 0.17 & 0.08 & 0.17 & 0.33 & 0.12 & 0.29 \\
\hline F-test $p$-value & 0.19 & 0.58 & $0.01^{* * *}$ & $0.03^{* *}$ & 0.60 & 0.32 & 0.28 & 0.25 & 0.21 & $0.03^{* *}$ & 0.43 & $0.07^{*}$ \\
\hline Country no & 58 & 34 & 24 & 13 & 32 & 8 & 31 & 31 & 22 & 7 & 57 & 24 \\
\hline
\end{tabular}

Sources: The iMaPP database, Bloomberg, BIS, OECD, others (see Appendix IV), and the authors' estimation.

Notes: The table reports the effects of a one-ppt LTV tightening, obtained by the fixed effects estimation with the timing assumption. The row labeled as "Sum coeff LTV level" shows the cumulative effects after four quarters. All specifications include country and time fixed effects. Period sample: 2000Q1 - 2016Q4. The p-value of the F-test regarding the sum of the LTV level

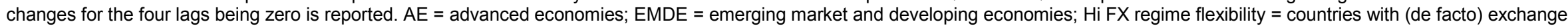

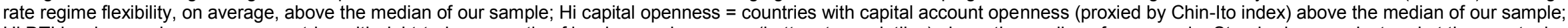

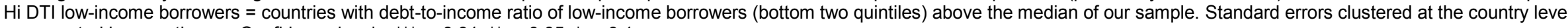
are reported in parentheses. Confidence levels: ${ }^{* * *} p<0.01,{ }^{* *} p<0.05,{ }^{*} p<0.1$ 


\section{Appendix VIII Table 10. Baseline: The Effects of $\Delta$ LTV Limits on Real Private Consumption Growth}

\begin{tabular}{|c|c|c|c|c|c|c|c|c|c|c|c|c|}
\hline \multirow[b]{3}{*}{ Group } & \multirow[t]{2}{*}{ (1) } & \multirow[t]{2}{*}{$(2)$} & \multirow[t]{2}{*}{ (3) } & (4) & $(5)$ & (6) & (7) & \multirow{2}{*}{\multicolumn{2}{|c|}{$\begin{array}{cr}(8) & (9) \\
\text { change, yoy, real) }\end{array}$}} & \multirow[t]{2}{*}{$(10)$} & \multirow[t]{2}{*}{$(11)$} & \multirow[t]{2}{*}{$(12)$} \\
\hline & & & & Dep & dent Variab & ble: Private $\mathrm{C}$ & onsumptic & & & & & \\
\hline & ALL & $\mathrm{AE}$ & EMDE & ASIA & EUROPE & AMERICAS & $\begin{array}{c}\text { Hi FX } \\
\text { Regime } \\
\text { Flexibility } \\
\end{array}$ & $\begin{array}{l}\text { Hi Capital } \\
\text { Openness }\end{array}$ & $\begin{array}{l}\text { Hi Financial } \\
\text { Development }\end{array}$ & $\begin{array}{l}\text { Hi DTI Low- } \\
\text { Income } \\
\text { Borrowers }\end{array}$ & $\begin{array}{l}\text { Positive } \\
\text { Credit Gap }\end{array}$ & $\begin{array}{c}\text { Positive } \\
\text { Credit Gap \& } \\
\text { EMDE only }\end{array}$ \\
\hline Private consumption ( $\%$ change, yoy, real, lag=1q) & $\begin{array}{l}0.830^{* * *} \\
(0.0217)\end{array}$ & $\begin{array}{l}0.842^{* * *} \\
(0.0239)\end{array}$ & $\begin{array}{l}0.827^{\star * *} \\
(0.0279)\end{array}$ & $\begin{array}{l}0.687^{* * *} \\
(0.0499)\end{array}$ & $\begin{array}{l}0.846^{* * *} \\
(0.0251)\end{array}$ & $\begin{array}{l}0.822^{* * *} \\
(0.0521)\end{array}$ & $\begin{array}{l}0.839^{* * *} \\
(0.0258)\end{array}$ & $\begin{array}{l}0.843^{* * *} \\
(0.0304)\end{array}$ & $\begin{array}{l}0.758^{* * *} \\
(0.0355)\end{array}$ & $\begin{array}{l}0.833^{* * *} \\
(0.0207)\end{array}$ & $\begin{array}{l}0.822^{* * *} \\
(0.0251)\end{array}$ & $\begin{array}{l}0.785^{* * *} \\
(0.0270)\end{array}$ \\
\hline Short-term interest rate $(\mathrm{lag}=1 \mathrm{q})$ & $\begin{array}{c}-0.0856^{* * *} \\
(0.0245)\end{array}$ & $\begin{array}{l}-0.0825^{* *} \\
(0.0359)\end{array}$ & $\begin{array}{c}-0.0843^{* * *} \\
(0.0269)\end{array}$ & $\begin{array}{l}-0.211^{* \star} \\
(0.0732)\end{array}$ & $\begin{array}{c}-0.0596^{* * *} \\
(0.0134)\end{array}$ & $\begin{array}{l}-0.119 \\
(0.102)\end{array}$ & $\begin{array}{l}-0.0864^{* * *} \\
(0.0284)\end{array}$ & $\begin{array}{l}-0.0714^{* *} \\
(0.0295)\end{array}$ & $\begin{array}{l}-0.0176 \\
(0.0294)\end{array}$ & $\begin{array}{l}-0.0953 \\
(0.0558)\end{array}$ & $\begin{array}{l}-0.112^{* * *} \\
(0.0204)\end{array}$ & $\begin{array}{l}-0.133^{* * *} \\
(0.0261)\end{array}$ \\
\hline GDP growth (real, lag=1q) & $\begin{array}{l}-0.0370 \\
(0.0277)\end{array}$ & $\begin{array}{l}-0.0623 \\
(0.0405)\end{array}$ & $\begin{array}{l}-0.0268 \\
(0.0417)\end{array}$ & $\begin{array}{l}-0.0616 \\
(0.0559)\end{array}$ & $\begin{array}{l}-0.0346 \\
(0.0323)\end{array}$ & $\begin{array}{l}-0.0578 \\
(0.0659)\end{array}$ & $\begin{array}{l}-0.108^{\star \star *} \\
(0.0332)\end{array}$ & $\begin{array}{l}-0.0310 \\
(0.0377)\end{array}$ & $\begin{array}{l}-0.0430 \\
(0.0366)\end{array}$ & $\begin{array}{l}0.00525 \\
(0.0272)\end{array}$ & $\begin{array}{l}-0.141^{* \star *} \\
(0.0463)\end{array}$ & $\begin{array}{l}-0.158^{*} \\
(0.0856)\end{array}$ \\
\hline $\begin{array}{l}\text { LTV level (change, lag=1q) } \\
\quad(-/+=\text { tightening/loosening) }\end{array}$ & $\begin{array}{c}-0.000850 \\
(0.0178)\end{array}$ & $\begin{array}{c}0.0157 \\
(0.0251)\end{array}$ & $\begin{array}{l}0.00237 \\
(0.0261)\end{array}$ & $\begin{array}{c}0.0112 \\
(0.0304)\end{array}$ & $\begin{array}{l}-0.0145 \\
(0.0244)\end{array}$ & $\begin{array}{l}0.0147 \\
(0.100)\end{array}$ & $\begin{array}{l}-0.00105 \\
(0.0255)\end{array}$ & $\begin{array}{c}0.0151 \\
(0.0222)\end{array}$ & $\begin{array}{c}0.0169 \\
(0.0215)\end{array}$ & $\begin{array}{c}0.0683 \\
(0.0964)\end{array}$ & $\begin{array}{l}-0.0208 \\
(0.0277)\end{array}$ & $\begin{array}{c}0.0142 \\
(0.0362)\end{array}$ \\
\hline LTV level (change, lag=2q) & $\begin{array}{c}0.0219 \\
(0.0193)\end{array}$ & $\begin{array}{l}0.00790 \\
(0.0148)\end{array}$ & $\begin{array}{c}0.0311 \\
(0.0321)\end{array}$ & $\begin{array}{l}-0.0158 \\
(0.0165)\end{array}$ & $\begin{array}{c}0.0104 \\
(0.0318)\end{array}$ & $\begin{array}{c}0.0181 \\
(0.0766)\end{array}$ & $\begin{array}{c}0.0188 \\
(0.0186)\end{array}$ & $\begin{array}{c}0.0346 \\
(0.0346)\end{array}$ & $\begin{array}{l}-0.0179 \\
(0.0168)\end{array}$ & $\begin{array}{c}0.0403 \\
(0.0643)\end{array}$ & $\begin{array}{l}0.0520^{*} \\
(0.0307)\end{array}$ & $\begin{array}{l}0.0773^{*} \\
(0.0395)\end{array}$ \\
\hline LTV level (change, lag=3q) & $\begin{array}{c}0.0130 \\
(0.0139)\end{array}$ & $\begin{array}{c}0.0179 \\
(0.0159)\end{array}$ & $\begin{array}{l}0.00427 \\
(0.0214)\end{array}$ & $\begin{array}{l}0.00823 \\
(0.0204)\end{array}$ & $\begin{array}{c}0.0174 \\
(0.0221)\end{array}$ & $\begin{array}{c}0.158 \\
(0.105)\end{array}$ & $\begin{array}{l}0.0311^{* *} \\
(0.0125)\end{array}$ & $\begin{array}{l}0.00600 \\
(0.0187)\end{array}$ & $\begin{array}{c}0.0190 \\
(0.0177)\end{array}$ & $\begin{array}{r}-0.00263 \\
(0.0335)\end{array}$ & $\begin{array}{l}0.00369 \\
(0.0194)\end{array}$ & $\begin{array}{l}0.00988 \\
(0.0283)\end{array}$ \\
\hline LTV level (change, lag=4q) & $\begin{array}{l}0.0422^{*} \\
(0.0236)\end{array}$ & $\begin{array}{r}-0.00592 \\
(0.0174)\end{array}$ & $\begin{array}{l}0.0767^{* *} \\
(0.0360)\end{array}$ & $\begin{array}{c}0.0396 \\
(0.0222)\end{array}$ & $\begin{array}{c}0.0398 \\
(0.0350)\end{array}$ & $\begin{array}{l}-0.0294 \\
(0.0477)\end{array}$ & $\begin{array}{c}0.0259 \\
(0.0250)\end{array}$ & $\begin{array}{c}0.0312 \\
(0.0395)\end{array}$ & $\begin{array}{l}-0.00845 \\
(0.0257)\end{array}$ & $\begin{array}{c}0.271 \\
(0.187)\end{array}$ & $\begin{array}{c}0.0500 \\
(0.0325)\end{array}$ & $\begin{array}{l}0.0766^{\star} \\
(0.0414)\end{array}$ \\
\hline Constant & $\begin{array}{c}0.111 \\
(0.473)\end{array}$ & $\begin{array}{l}0.0345 \\
(0.440)\end{array}$ & $\begin{array}{c}0.171 \\
(0.891)\end{array}$ & $\begin{array}{l}2.096^{*} \\
(1.057)\end{array}$ & $\begin{array}{l}-0.447 \\
(0.533)\end{array}$ & $\begin{array}{c}1.487 \\
(2.057)\end{array}$ & $\begin{array}{c}0.546 \\
(0.579)\end{array}$ & $\begin{array}{l}-0.0593 \\
(0.326)\end{array}$ & $\begin{array}{l}-0.0153 \\
(0.410)\end{array}$ & $\begin{array}{c}0.105 \\
(0.725)\end{array}$ & $\begin{array}{c}0.408 \\
(0.777)\end{array}$ & $\begin{array}{c}1.025 \\
(1.549)\end{array}$ \\
\hline Observations & 3,187 & 1,953 & 1,360 & 693 & 1,817 & 468 & 1,854 & 1,764 & 1,197 & 441 & 1,400 & 545 \\
\hline R-squared & 0.824 & 0.814 & 0.841 & 0.724 & 0.837 & 0.874 & 0.851 & 0.808 & 0.778 & 0.840 & 0.833 & 0.858 \\
\hline Sum coeff LTV level & 0.08 & 0.04 & 0.11 & 0.04 & 0.05 & 0.16 & 0.07 & 0.09 & 0.01 & 0.38 & 0.08 & 0.18 \\
\hline F-test p-value & $0.08^{*}$ & 0.48 & $0.09^{*}$ & 0.57 & 0.43 & 0.40 & 0.16 & 0.27 & 0.89 & 0.17 & 0.21 & $0.06^{*}$ \\
\hline Country no & 54 & 31 & 23 & 11 & 29 & 8 & 30 & 29 & 19 & 7 & 51 & 23 \\
\hline
\end{tabular}

Sources: The iMaPP database, Bloomberg, BIS, OECD, others (see Appendix IV), and the authors' estimation.

Notes: The table reports the effects of a one-ppt LTV tightening, obtained by the fixed effects estimation with the timing assumption. The row labeled as "Sum coeff LTV level" shows the cumulative effects after four quarters. All specifications include country and time fixed effects. Period sample: 2000Q1-2016Q4. The p-value of the F-test regarding the sum of the LTV level changes for the four lags being zero is reported. $\mathrm{AE}=$ advanced economies; $\mathrm{EMDE}=$ emerging market and developing economies; Hi $\mathrm{FX}$ regime flexibility $=$ countries with (de facto)

exchange rate regime flexibility, on average, above the median of our sample; Hi capital openness = countries with capital account openness (proxied by Chin-Ito index) above the median of our sample; Hi DTI low-income borrowers = countries with debt-to-income ratio of low-income borrowers (bottom two quintiles) above the median of our sample. Standard errors clustered at the country level are reported in parentheses. Confidence levels: ${ }^{* *} p<0.01,{ }^{\star *} p<0.05,{ }^{*} p<0.1$. 
Appendix VIII Table 11. Robustness (Control f. other MaPPs): Effects of $\Delta$ LTV Limits on Real Household Credit Growth

\begin{tabular}{|c|c|c|c|c|c|c|c|c|c|c|c|c|}
\hline \multirow[b]{3}{*}{ Group } & \multirow[t]{2}{*}{ (1) } & \multirow[t]{2}{*}{ (2) } & \multirow[t]{2}{*}{ (3) } & \multirow{2}{*}{\multicolumn{6}{|c|}{$\begin{array}{lcccc}(4) & (5) & (7) & (8) & (9) \\
& \text { Dependent Variable: Household Credit }(\% \text { change, yoy, real) } \\
\end{array}$}} & \multirow[t]{2}{*}{ (10) } & \multirow[t]{2}{*}{ (11) } & \multirow{3}{*}{$\begin{array}{c}\text { (12) } \\
\text { Positive } \\
\text { Credit Gap } 8 \\
\text { EMDE only }\end{array}$} \\
\hline & & & & & & & & & & & & \\
\hline & ALL & $\mathrm{AE}$ & EMDE & ASIA & EUROPE & \multicolumn{2}{|c|}{$\begin{array}{cc} & H i \text { FX } \\
& \text { Regime } \\
\text { AMERICAS } & \text { Flexibility } \\
\end{array}$} & $\begin{array}{l}\text { Hi Capital } \\
\text { Openness }\end{array}$ & $\begin{array}{l}\text { Hi Financial } \\
\text { Development }\end{array}$ & $\begin{array}{l}\text { Hi DTI Low- } \\
\text { Income } \\
\text { Borrowers }\end{array}$ & $\begin{array}{l}\text { Positive } \\
\text { Credit Gap }\end{array}$ & \\
\hline Household credit ( $\%$ change, yoy, real, lag=1q) & $\begin{array}{l}0.898^{\star \star *} \\
(0.0163)\end{array}$ & $\begin{array}{l}0.910^{* \star *} \\
(0.0408)\end{array}$ & $\begin{array}{l}0.894^{* \star *} \\
(0.0137)\end{array}$ & $\begin{array}{l}0.841^{* * *} \\
(0.0288)\end{array}$ & $\begin{array}{l}0.911^{* * *} \\
(0.0212)\end{array}$ & $\begin{array}{l}0.820^{\star \star \star} \\
(0.0192)\end{array}$ & $\begin{array}{l}0.886^{* \star *} \\
(0.0231)\end{array}$ & $\begin{array}{l}0.906^{\star * *} \\
(0.0368)\end{array}$ & $\begin{array}{l}0.900^{\star \star *} \\
(0.0385)\end{array}$ & $\begin{array}{l}0.965^{\star \star \star} \\
(0.00929)\end{array}$ & $\begin{array}{l}0.867^{\star \star *} \\
(0.0270)\end{array}$ & $\begin{array}{l}0.855^{\star \star *} \\
(0.0265)\end{array}$ \\
\hline Short-term interest rate $(\mathrm{lag}=1 \mathrm{q})$ & $\begin{array}{c}-0.0857^{* * *} \\
(0.0225)\end{array}$ & $\begin{array}{c}-0.101 \\
(0.0765)\end{array}$ & $\begin{array}{l}-0.0995^{\star *} \\
(0.0356)\end{array}$ & $\begin{array}{l}-0.413 \\
(0.302)\end{array}$ & $\begin{array}{l}-0.101^{* * *} \\
(0.0151)\end{array}$ & $\begin{array}{l}-0.0525 \\
(0.0307)\end{array}$ & $\begin{array}{c}-0.0859^{* * *} \\
(0.0240)\end{array}$ & $\begin{array}{c}-0.0459^{* * *} \\
(0.0136)\end{array}$ & $\begin{array}{l}-0.129^{*} \\
(0.0721)\end{array}$ & $\begin{array}{l}-0.0993^{* *} \\
(0.0292)\end{array}$ & $\begin{array}{l}-0.145^{\star \star} \\
(0.0599)\end{array}$ & $\begin{array}{l}-0.141^{* *} \\
(0.0681)\end{array}$ \\
\hline GDP growth (real, lag=1q) & $\begin{array}{l}0.147^{\star \star *} \\
(0.0522)\end{array}$ & $\begin{array}{c}0.112^{*} \\
(0.0643)\end{array}$ & $\begin{array}{c}0.201^{* *} \\
(0.0823)\end{array}$ & $\begin{array}{l}0.0717 \\
(0.132)\end{array}$ & $\begin{array}{c}0.0971 \\
(0.0680)\end{array}$ & $\begin{array}{l}0.345^{\star * *} \\
(0.0868)\end{array}$ & $\begin{array}{l}0.156^{\star *} \\
(0.0725)\end{array}$ & $\begin{array}{c}0.0937 \\
(0.0673)\end{array}$ & $\begin{array}{c}0.105 \\
(0.0639)\end{array}$ & $\begin{array}{c}0.0144 \\
(0.0282)\end{array}$ & $\begin{array}{c}0.0747 \\
(0.0729)\end{array}$ & $\begin{array}{l}-0.0909 \\
(0.125)\end{array}$ \\
\hline $\begin{array}{l}\text { LTV level (change, lag=1q) } \\
\quad(-/+=\text { tightening/loosening) }\end{array}$ & $\begin{array}{l}0.00808 \\
(0.0354)\end{array}$ & $\begin{array}{c}0.0337 \\
(0.0335)\end{array}$ & $\begin{array}{c}0.0194 \\
(0.0610)\end{array}$ & $\begin{array}{l}0.0629^{*} \\
(0.0310)\end{array}$ & $\begin{array}{l}-0.0519 \\
(0.0608)\end{array}$ & $\begin{array}{l}0.163^{\star * \star} \\
(0.0352)\end{array}$ & $\begin{array}{c}0.0109 \\
(0.0455)\end{array}$ & $\begin{array}{l}0.0298 \\
(0.0211)\end{array}$ & $\begin{array}{c}0.0590 \\
(0.0353)\end{array}$ & $\begin{array}{l}0.0288 \\
(0.0315)\end{array}$ & $\begin{array}{l}-0.0442 \\
(0.0476)\end{array}$ & $\begin{array}{l}-0.0599 \\
(0.0692)\end{array}$ \\
\hline LTV level (change, lag=2q) & $\begin{array}{l}0.0187 \\
(0.0476)\end{array}$ & $\begin{array}{l}-0.0365 \\
(0.0701)\end{array}$ & $\begin{array}{c}0.100^{\star *} \\
(0.0447)\end{array}$ & $\begin{array}{c}0.0614 \\
(0.0360)\end{array}$ & $\begin{array}{c}0.0207 \\
(0.0698)\end{array}$ & $\begin{array}{l}0.0250 \\
(0.130)\end{array}$ & $\begin{array}{c}0.0404 \\
(0.0644)\end{array}$ & $\begin{array}{l}0.0129 \\
(0.0193)\end{array}$ & $\begin{array}{l}0.00285 \\
(0.0395)\end{array}$ & $\begin{array}{l}0.0735 \\
(0.0412)\end{array}$ & $\begin{array}{l}0.0516 \\
(0.0479)\end{array}$ & $\begin{array}{l}0.0992^{\star * *} \\
(0.0305)\end{array}$ \\
\hline LTV level (change, lag=3q) & $\begin{array}{c}0.0310 \\
(0.0374)\end{array}$ & $\begin{array}{c}0.0284 \\
(0.0358)\end{array}$ & $\begin{array}{l}0.0795^{\star} \\
(0.0434)\end{array}$ & $\begin{array}{l}0.0687^{\star *} \\
(0.0310)\end{array}$ & $\begin{array}{c}0.0257 \\
(0.0610)\end{array}$ & $\begin{array}{c}0.158 \\
(0.0917)\end{array}$ & $\begin{array}{c}0.0526 \\
(0.0508)\end{array}$ & $\begin{array}{c}0.0234 \\
(0.0236)\end{array}$ & $\begin{array}{l}0.0107 \\
(0.0404)\end{array}$ & $\begin{array}{c}0.0587 \\
(0.0681)\end{array}$ & $\begin{array}{c}0.0641 \\
(0.0621)\end{array}$ & $\begin{array}{c}0.107^{*} \\
(0.0582)\end{array}$ \\
\hline LTV level (change, lag=4q) & $\begin{array}{c}0.0215 \\
(0.0278)\end{array}$ & $\begin{array}{l}0.00261 \\
(0.0201)\end{array}$ & $\begin{array}{l}0.0797^{* *} \\
(0.0300)\end{array}$ & $\begin{array}{c}0.0493 \\
(0.0421)\end{array}$ & $\begin{array}{c}0.0139 \\
(0.0343)\end{array}$ & $\begin{array}{l}0.0803 \\
(0.200)\end{array}$ & $\begin{array}{c}0.0402 \\
(0.0398)\end{array}$ & $\begin{array}{l}0.00950 \\
(0.0294)\end{array}$ & $\begin{array}{l}-0.000995 \\
(0.0375)\end{array}$ & $\begin{array}{l}0.132^{\star *} \\
(0.0432)\end{array}$ & $\begin{array}{l}0.0599^{*} \\
(0.0352)\end{array}$ & $\begin{array}{l}0.115^{\star * *} \\
(0.0334)\end{array}$ \\
\hline $\begin{array}{c}\text { Other MPPs (except LTV, lag=1q) } \\
\quad(+/-=\text { tightening/loosening) }\end{array}$ & $\begin{array}{l}-0.0836 \\
(0.163)\end{array}$ & $\begin{array}{l}0.0185 \\
(0.164)\end{array}$ & $\begin{array}{l}-0.261 \\
(0.230)\end{array}$ & $\begin{array}{l}-0.251 \\
(0.189)\end{array}$ & $\begin{array}{l}0.0383 \\
(0.215)\end{array}$ & $\begin{array}{l}-0.0660 \\
(0.323)\end{array}$ & $\begin{array}{c}0.108 \\
(0.222)\end{array}$ & $\begin{array}{c}0.169 \\
(0.188)\end{array}$ & $\begin{array}{c}-0.260^{* *} \\
(0.112)\end{array}$ & $\begin{array}{l}-0.185 \\
(0.145)\end{array}$ & $\begin{array}{c}0.296 \\
(0.197)\end{array}$ & $\begin{array}{l}0.0323 \\
(0.227)\end{array}$ \\
\hline Other MPPs (except LTV, lag=2q) & $\begin{array}{c}-0.380^{\star *} \\
(0.162)\end{array}$ & $\begin{array}{c}-0.194^{*} \\
(0.0987)\end{array}$ & $\begin{array}{c}-0.480^{\star *} \\
(0.230)\end{array}$ & $\begin{array}{l}-0.408 \\
(0.302)\end{array}$ & $\begin{array}{l}-0.468^{*} \\
(0.248)\end{array}$ & $\begin{array}{l}-0.191 \\
(0.222)\end{array}$ & $\begin{array}{l}-0.164 \\
(0.127)\end{array}$ & $\begin{array}{l}-0.260 \\
(0.156)\end{array}$ & $\begin{array}{c}-0.480^{\star \star \star} \\
(0.166)\end{array}$ & $\begin{array}{c}-0.0993 \\
(0.157)\end{array}$ & $\begin{array}{l}-0.0488 \\
(0.203)\end{array}$ & $\begin{array}{l}-0.192 \\
(0.214)\end{array}$ \\
\hline Other MPPs (except LTV, lag=3q) & $\begin{array}{l}-0.233^{*} \\
(0.132)\end{array}$ & $\begin{array}{l}-0.153 \\
(0.155)\end{array}$ & $\begin{array}{l}-0.270 \\
(0.169)\end{array}$ & $\begin{array}{l}-0.302^{*} \\
(0.163)\end{array}$ & $\begin{array}{l}-0.276 \\
(0.219)\end{array}$ & $\begin{array}{c}0.118 \\
(0.119)\end{array}$ & $\begin{array}{l}-0.111 \\
(0.139)\end{array}$ & $\begin{array}{c}0.158 \\
(0.157)\end{array}$ & $\begin{array}{c}-0.430^{\star \star *} \\
(0.0956)\end{array}$ & $\begin{array}{l}0.0583 \\
(0.135)\end{array}$ & $\begin{array}{l}-0.0172 \\
(0.168)\end{array}$ & $\begin{array}{l}-0.206 \\
(0.234)\end{array}$ \\
\hline Other MPPs (except LTV, lag=4q) & $\begin{array}{l}-0.307^{*} \\
(0.161)\end{array}$ & $\begin{array}{c}-0.449^{\star *} \\
(0.211)\end{array}$ & $\begin{array}{l}-0.263 \\
(0.194)\end{array}$ & $\begin{array}{l}-0.479 \\
(0.283)\end{array}$ & $\begin{array}{l}-0.188 \\
(0.186)\end{array}$ & $\begin{array}{l}-0.435 \\
(0.753)\end{array}$ & $\begin{array}{l}-0.354 \\
(0.229)\end{array}$ & $\begin{array}{l}-0.568 \\
(0.354)\end{array}$ & $\begin{array}{c}-0.521^{* *} \\
(0.226)\end{array}$ & $\begin{array}{l}-0.160 \\
(0.350)\end{array}$ & $\begin{array}{l}0.0676 \\
(0.141)\end{array}$ & $\begin{array}{c}-0.0219 \\
(0.288)\end{array}$ \\
\hline Constant & $\begin{array}{l}-1.634 \\
(1.957)\end{array}$ & $\begin{array}{c}1.193 \\
(0.988)\end{array}$ & $\begin{array}{l}-8.423 \\
(6.197)\end{array}$ & $\begin{array}{c}3.451 \\
(2.311)\end{array}$ & $\begin{array}{l}-0.928 \\
(2.514)\end{array}$ & $\begin{array}{l}-6.183 \\
(7.052)\end{array}$ & $\begin{array}{l}-2.975 \\
(3.090)\end{array}$ & $\begin{array}{c}0.923 \\
(0.717)\end{array}$ & $\begin{array}{c}0.587 \\
(0.515)\end{array}$ & $\begin{array}{c}0.185 \\
(0.296)\end{array}$ & $\begin{array}{l}-6.284 \\
(4.296)\end{array}$ & $\begin{array}{l}-20.27^{*} \\
(11.18)\end{array}$ \\
\hline Observations & 3,118 & 1,900 & 1,262 & 612 & 1,883 & 479 & 1,799 & 1,728 & 1,184 & 435 & 1,455 & 526 \\
\hline R-squared & 0.927 & 0.938 & 0.935 & 0.882 & 0.945 & 0.893 & 0.907 & 0.934 & 0.929 & 0.986 & 0.926 & 0.940 \\
\hline Sum coeff LTV level & 0.08 & 0.03 & 0.28 & 0.24 & 0.01 & 0.43 & 0.14 & 0.08 & 0.07 & 0.29 & 0.13 & 0.26 \\
\hline F-test $p$-value & 0.51 & 0.84 & $0.04^{* *}$ & $0.05^{\star}$ & 0.96 & 0.33 & 0.36 & 0.30 & 0.60 & $0.03^{\star *}$ & 0.38 & $0.08^{*}$ \\
\hline Countries & 56 & 32 & 24 & 12 & 32 & 8 & 31 & 30 & 20 & 7 & 55 & 24 \\
\hline
\end{tabular}

Sources: The iMaPP database, Bloomberg, BIS, OECD, others (see Appendix IV), and the authors' estimation.

Notes: The table reports the effects of a one-ppt LTV tightening when additionally controlling for other macroprudential policy actions, obtained by the fixed effects estimation with the timing assumption. The row labeled as "Sum coeff LTV level" shows the cumulative effects after four quarters. All specifications include country and time fixed effects. Period sample: $2000 \mathrm{Q} 1-$ 2016Q4. AE = advanced economies; and EMDE = emerging market and developing economies. The p-value of the F-test regarding the sum of the LTV level changes for the four lags being zero is reported. Standard errors clustered at the country level are reported in parentheses. Confidence levels: ${ }^{* * *} p<0.01,{ }^{* *} p<0.05,{ }^{*} p<0.1$. 


\section{Appendix VIII Table 12. Robustness (Control for Other MaPPs): The Effects of $\Delta$ LTV Limits on Real Private Consumption Growth}

\begin{tabular}{|c|c|c|c|c|c|c|c|c|c|c|c|c|}
\hline \multirow[b]{3}{*}{ Group } & \multirow[t]{2}{*}{$(1)$} & \multirow[t]{2}{*}{$(2)$} & \multirow[t]{2}{*}{ (3) } & (4) & (5) & (6) & $(7)$ & \multirow{2}{*}{\multicolumn{2}{|c|}{$\begin{array}{cr}(8) & (9) \\
\text { change, yoy, real) }\end{array}$}} & \multirow[t]{2}{*}{$(10)$} & \multirow[t]{2}{*}{$(11)$} & \multirow[t]{2}{*}{$(12)$} \\
\hline & & & & Dep & ndent Varia & ble: Private C & onsumption & & & & & \\
\hline & ALL & $\mathrm{AE}$ & EMDE & ASIA & EUROPE & AMERICAS & $\begin{array}{c}\text { Hi FX } \\
\text { Regime } \\
\text { Flexibility } \\
\end{array}$ & $\begin{array}{l}\text { Hi Capital } \\
\text { Openness }\end{array}$ & $\begin{array}{l}\text { Hi Financial } \\
\text { Development }\end{array}$ & $\begin{array}{l}\text { Hi DTI Low- } \\
\text { Income } \\
\text { Borrowers }\end{array}$ & $\begin{array}{l}\text { Positive } \\
\text { Credit Gap }\end{array}$ & $\begin{array}{c}\text { Positive } \\
\text { Credit Gap \& } \\
\text { EMDE only }\end{array}$ \\
\hline Private consumption ( $\%$ change, yoy, real, lag=1q) & $\begin{array}{l}0.832^{* * *} \\
(0.0218)\end{array}$ & $\begin{array}{l}0.845^{\star * *} \\
(0.0236)\end{array}$ & $\begin{array}{l}0.828^{* * *} \\
(0.0283)\end{array}$ & $\begin{array}{l}0.681^{\star * *} \\
(0.0575)\end{array}$ & $\begin{array}{l}0.847^{* * *} \\
(0.0254)\end{array}$ & $\begin{array}{l}0.824^{* * *} \\
(0.0542)\end{array}$ & $\begin{array}{l}0.839^{* * *} \\
(0.0259)\end{array}$ & $\begin{array}{l}0.847^{* \star *} \\
(0.0294)\end{array}$ & $\begin{array}{l}0.766^{* * *} \\
(0.0391)\end{array}$ & $\begin{array}{l}0.823^{* * *} \\
(0.0191)\end{array}$ & $\begin{array}{l}0.821^{* * *} \\
(0.0251)\end{array}$ & $\begin{array}{l}0.789^{* * *} \\
(0.0262)\end{array}$ \\
\hline Short-term interest rate $(\mathrm{lag}=1 \mathrm{q})$ & $\begin{array}{c}-0.0851^{\star \star *} \\
(0.0246)\end{array}$ & $\begin{array}{l}-0.0852^{* *} \\
(0.0364)\end{array}$ & $\begin{array}{c}-0.0843^{\star \star \star} \\
(0.0270)\end{array}$ & $\begin{array}{l}-0.281^{* \star *} \\
(0.0695)\end{array}$ & $\begin{array}{c}-0.0594^{\star \star *} \\
(0.0136)\end{array}$ & $\begin{array}{l}-0.127 \\
(0.105)\end{array}$ & $\begin{array}{c}-0.0852^{\star \star *} \\
(0.0280)\end{array}$ & $\begin{array}{c}-0.0743^{* *} \\
(0.0309)\end{array}$ & $\begin{array}{l}-0.0305 \\
(0.0263)\end{array}$ & $\begin{array}{l}-0.0937 \\
(0.0540)\end{array}$ & $\begin{array}{l}-0.114^{\star * *} \\
(0.0207)\end{array}$ & $\begin{array}{l}-0.133^{\star \star *} \\
(0.0274)\end{array}$ \\
\hline GDP growth (real, lag=1q) & $\begin{array}{l}-0.0380 \\
(0.0279)\end{array}$ & $\begin{array}{l}-0.0633 \\
(0.0407)\end{array}$ & $\begin{array}{l}-0.0280 \\
(0.0412)\end{array}$ & $\begin{array}{l}-0.0923 \\
(0.0536)\end{array}$ & $\begin{array}{l}-0.0328 \\
(0.0315)\end{array}$ & $\begin{array}{l}-0.0634 \\
(0.0641)\end{array}$ & $\begin{array}{l}-0.105^{\star \star \star} \\
(0.0327)\end{array}$ & $\begin{array}{l}-0.0304 \\
(0.0393)\end{array}$ & $\begin{array}{l}-0.0434 \\
(0.0390)\end{array}$ & $\begin{array}{c}0.0127 \\
(0.0277)\end{array}$ & $\begin{array}{l}-0.156^{\star \star \star} \\
(0.0471)\end{array}$ & $\begin{array}{l}-0.170^{\star} \\
(0.0934)\end{array}$ \\
\hline $\begin{array}{l}\text { LTV level (change, lag=1q) } \\
\quad(-/+=\text { tightening/loosening })\end{array}$ & $\begin{array}{l}0.000548 \\
(0.0189)\end{array}$ & $\begin{array}{l}0.0209 \\
(0.0276)\end{array}$ & $\begin{array}{l}-0.00172 \\
(0.0288)\end{array}$ & $\begin{array}{c}0.0207 \\
(0.0365)\end{array}$ & $\begin{array}{l}-0.0142 \\
(0.0267)\end{array}$ & $\begin{array}{l}0.00836 \\
(0.124)\end{array}$ & $\begin{array}{l}0.00140 \\
(0.0257)\end{array}$ & $\begin{array}{l}0.0181 \\
(0.0257)\end{array}$ & $\begin{array}{c}0.0233 \\
(0.0232)\end{array}$ & $\begin{array}{l}0.0429 \\
(0.100)\end{array}$ & $\begin{array}{l}-0.0163 \\
(0.0304)\end{array}$ & $\begin{array}{c}0.0113 \\
(0.0405)\end{array}$ \\
\hline LTV level (change, lag=2q) & $\begin{array}{c}0.0242 \\
(0.0203)\end{array}$ & $\begin{array}{l}0.00979 \\
(0.0160)\end{array}$ & $\begin{array}{l}0.0318 \\
(0.0343)\end{array}$ & $\begin{array}{l}-0.0165 \\
(0.0149)\end{array}$ & $\begin{array}{l}0.0127 \\
(0.0336)\end{array}$ & $\begin{array}{l}0.0503 \\
(0.0827)\end{array}$ & $\begin{array}{c}0.0217 \\
(0.0195)\end{array}$ & $\begin{array}{c}0.0357 \\
(0.0369)\end{array}$ & $\begin{array}{l}-0.0199 \\
(0.0159)\end{array}$ & $\begin{array}{c}0.0427 \\
(0.0619)\end{array}$ & $\begin{array}{l}0.0616^{*} \\
(0.0321)\end{array}$ & $\begin{array}{l}0.0794^{*} \\
(0.0424)\end{array}$ \\
\hline LTV level (change, lag=3q) & $\begin{array}{c}0.0142 \\
(0.0140)\end{array}$ & $\begin{array}{l}0.00923 \\
(0.0179)\end{array}$ & $\begin{array}{c}0.0145 \\
(0.0232)\end{array}$ & $\begin{array}{c}0.0106 \\
(0.0249)\end{array}$ & $\begin{array}{c}0.0167 \\
(0.0221)\end{array}$ & $\begin{array}{c}0.154 \\
(0.107)\end{array}$ & $\begin{array}{l}0.0320^{\star *} \\
(0.0141)\end{array}$ & $\begin{array}{l}-0.00492 \\
(0.0206)\end{array}$ & $\begin{array}{l}0.00882 \\
(0.0175)\end{array}$ & $\begin{array}{l}-0.0537 \\
(0.0390)\end{array}$ & $\begin{array}{c}0.0132 \\
(0.0215)\end{array}$ & $\begin{array}{c}0.0253 \\
(0.0317)\end{array}$ \\
\hline LTV level (change, lag=4q) & $\begin{array}{l}0.0423^{*} \\
(0.0244)\end{array}$ & $\begin{array}{l}-0.00959 \\
(0.0164)\end{array}$ & $\begin{array}{l}0.0821^{* *} \\
(0.0374)\end{array}$ & $\begin{array}{l}0.0451^{*} \\
(0.0216)\end{array}$ & $\begin{array}{c}0.0362 \\
(0.0363)\end{array}$ & $\begin{array}{l}-0.0126 \\
(0.0380)\end{array}$ & $\begin{array}{c}0.0169 \\
(0.0223)\end{array}$ & $\begin{array}{l}0.0306 \\
(0.0384)\end{array}$ & $\begin{array}{l}-0.0125 \\
(0.0242)\end{array}$ & $\begin{array}{l}0.270 \\
(0.192)\end{array}$ & $\begin{array}{l}0.0568^{*} \\
(0.0333)\end{array}$ & $\begin{array}{l}0.0907^{* *} \\
(0.0433)\end{array}$ \\
\hline $\begin{array}{l}\text { Other MPPs (except LTV, lag=1q) } \\
\quad(+/-=\text { tightening/loosening) }\end{array}$ & $\begin{array}{l}-0.00825 \\
(0.0893)\end{array}$ & $\begin{array}{l}0.191^{*} \\
(0.106)\end{array}$ & $\begin{array}{l}-0.176 \\
(0.143)\end{array}$ & $\begin{array}{c}0.212 \\
(0.116)\end{array}$ & $\begin{array}{l}-0.0532 \\
(0.122)\end{array}$ & $\begin{array}{l}-0.0874 \\
(0.251)\end{array}$ & $\begin{array}{l}-0.0341 \\
(0.0814)\end{array}$ & $\begin{array}{l}0.229^{*} \\
(0.122)\end{array}$ & $\begin{array}{c}0.135 \\
(0.0835)\end{array}$ & $\begin{array}{l}-0.290 \\
(0.163)\end{array}$ & $\begin{array}{l}0.0769 \\
(0.155)\end{array}$ & $\begin{array}{l}-0.105 \\
(0.199)\end{array}$ \\
\hline Other MPPs (except LTV, lag=2q) & $\begin{array}{l}0.0419 \\
(0.100)\end{array}$ & $\begin{array}{l}0.0527 \\
(0.155)\end{array}$ & $\begin{array}{l}0.0360 \\
(0.158)\end{array}$ & $\begin{array}{l}-0.0990 \\
(0.0612)\end{array}$ & $\begin{array}{l}0.0324 \\
(0.161)\end{array}$ & $\begin{array}{c}0.463 \\
(0.412)\end{array}$ & $\begin{array}{c}0.180 \\
(0.125)\end{array}$ & $\begin{array}{l}0.0609 \\
(0.153)\end{array}$ & $\begin{array}{l}-0.0730 \\
(0.0784)\end{array}$ & $\begin{array}{l}-0.0213 \\
(0.149)\end{array}$ & $\begin{array}{l}0.0946 \\
(0.188)\end{array}$ & $\begin{array}{c}-0.000334 \\
(0.286)\end{array}$ \\
\hline Other MPPs (except LTV, lag=3q) & $\begin{array}{c}0.127 \\
(0.121)\end{array}$ & $\begin{array}{l}-0.0552 \\
(0.130)\end{array}$ & $\begin{array}{c}0.239 \\
(0.155)\end{array}$ & $\begin{array}{c}0.364 \\
(0.236)\end{array}$ & $\begin{array}{c}0.153 \\
(0.160)\end{array}$ & $\begin{array}{l}-0.133 \\
(0.242)\end{array}$ & $\begin{array}{l}-0.0458 \\
(0.106)\end{array}$ & $\begin{array}{l}-0.0650 \\
(0.209)\end{array}$ & $\begin{array}{c}-0.0612 \\
(0.0781)\end{array}$ & $\begin{array}{l}0.0189 \\
(0.181)\end{array}$ & $\begin{array}{l}0.315^{\star *} \\
(0.141)\end{array}$ & $\begin{array}{l}0.325^{* *} \\
(0.152)\end{array}$ \\
\hline Other MPPs (except LTV, lag=4q) & $\begin{array}{l}-0.113 \\
(0.120)\end{array}$ & $\begin{array}{c}-0.275^{* *} \\
(0.134)\end{array}$ & $\begin{array}{l}-0.0476 \\
(0.169)\end{array}$ & $\begin{array}{c}-0.0255 \\
(0.126)\end{array}$ & $\begin{array}{l}-0.227 \\
(0.136)\end{array}$ & $\begin{array}{c}0.185 \\
(0.169)\end{array}$ & $\begin{array}{l}-0.236 \\
(0.147)\end{array}$ & $\begin{array}{l}-0.345^{\star *} \\
(0.161)\end{array}$ & $\begin{array}{l}-0.168^{*} \\
(0.0916)\end{array}$ & $\begin{array}{l}-0.527^{* *} \\
(0.165)\end{array}$ & $\begin{array}{l}0.0318 \\
(0.174)\end{array}$ & $\begin{array}{c}0.167 \\
(0.254)\end{array}$ \\
\hline Constant & $\begin{array}{l}0.0904 \\
(0.480)\end{array}$ & $\begin{array}{l}0.0307 \\
(0.439)\end{array}$ & $\begin{array}{c}0.157 \\
(0.888)\end{array}$ & $\begin{array}{l}2.763^{* *} \\
(1.191)\end{array}$ & $\begin{array}{l}-0.475 \\
(0.525)\end{array}$ & $\begin{array}{c}1.689 \\
(2.030)\end{array}$ & $\begin{array}{c}0.519 \\
(0.578)\end{array}$ & $\begin{array}{l}-0.0763 \\
(0.327)\end{array}$ & $\begin{array}{l}0.0404 \\
(0.432)\end{array}$ & $\begin{array}{l}-0.0960 \\
(0.551)\end{array}$ & $\begin{array}{c}0.508 \\
(0.787)\end{array}$ & $\begin{array}{c}1.165 \\
(1.644)\end{array}$ \\
\hline Observations & 3,124 & 1,890 & 1,360 & 630 & 1,817 & 468 & 1,854 & 1,701 & 1,134 & 441 & 1,377 & 545 \\
\hline R-squared & 0.826 & 0.818 & 0.842 & 0.738 & 0.838 & 0.876 & 0.851 & 0.813 & 0.789 & 0.842 & 0.834 & 0.859 \\
\hline Sum coeff LTV level & 0.08 & 0.03 & 0.13 & 0.06 & 0.05 & 0.20 & 0.07 & 0.08 & 0.00 & 0.30 & 0.12 & 0.21 \\
\hline F-test p-value & $0.08^{\star}$ & 0.57 & $0.08^{*}$ & 0.47 & 0.44 & 0.32 & 0.14 & 0.34 & 1.00 & 0.28 & 0.12 & $0.04^{*}$ \\
\hline Countries & 53 & 30 & 23 & 10 & 29 & 8 & 30 & 28 & 18 & 7 & 50 & 23 \\
\hline
\end{tabular}

Sources: The iMaPP database, Bloomberg, BIS, OECD, others (see Appendix IV), and the authors' estimation.

Notes: The table reports the effects of a one-ppt LTV tightening when additionally controlling for other macroprudential policy actions, obtained by the fixed effects estimation with the timing assumption. The row labeled as "Sum coeff LTV level" shows the cumulative effects after four quarters. All specifications include country and time fixed effects. Period sample: $2000 \mathrm{Q} 1-$ 2016Q4. AE = advanced economies; and EMDE = emerging market and developing economies. The p-value of the F-test regarding the sum of the LTV level changes for the four lags being zero is reported. Standard errors clustered at the country level are reported in parentheses. Confidence levels: ${ }^{* * *} p<0.01,{ }^{* *} p<0.05,{ }^{*} p<0.1$. 


\section{Appendix VIII Table 13. Robustness (system GMM): The Effects of $\Delta$ LTV Limits on Real Household Credit Growth}

\begin{tabular}{|c|c|c|c|c|c|c|c|c|c|c|c|c|}
\hline \multirow[b]{3}{*}{ Group } & \multirow[t]{2}{*}{ (1) } & \multirow[t]{2}{*}{ (2) } & \multirow[t]{2}{*}{ (3) } & (4) & (5) & (6) & $(7)$ & \multirow{2}{*}{\multicolumn{2}{|c|}{$\begin{array}{cc}(8) & (9) \\
\text { change, yoy, real) }\end{array}$}} & \multirow[t]{2}{*}{$(10)$} & \multirow[t]{2}{*}{$(11)$} & \multirow{3}{*}{$\begin{array}{c}\text { (12) } \\
\text { Positive } \\
\text { Credit Gap \& } \\
\text { EMDE only } \\
\end{array}$} \\
\hline & & & & De & dent $\mathrm{V}$ & le: $\mathrm{Hou}$ & Credit ( & & & & & \\
\hline & ALL & $\mathrm{AE}$ & EMDE & ASIA & EUROPE & \multicolumn{2}{|c|}{$\begin{array}{cc}\text { Hi FX } \\
\text { Regime } \\
\text { AS } \quad \text { Flexibility } \\
\end{array}$} & $\begin{array}{l}\text { Hi Capital } \\
\text { Openness } \\
\end{array}$ & $\begin{array}{l}\text { Hi Financial } \\
\text { Development }\end{array}$ & $\begin{array}{l}\text { Hi DTI Low- } \\
\text { Income } \\
\text { Borrowers }\end{array}$ & $\begin{array}{l}\text { Positive } \\
\text { Credit Gap }\end{array}$ & \\
\hline Household credit ( $\%$ change, yoy, real, lag=1q) & $\begin{array}{l}0.912^{* * *} \\
(0.0141)\end{array}$ & $\begin{array}{l}0.912^{* * *} \\
(0.0346)\end{array}$ & $\begin{array}{l}0.907^{* * *} \\
(0.0105)\end{array}$ & $\begin{array}{l}0.809^{\star * *} \\
(0.0440)\end{array}$ & $\begin{array}{l}0.929^{* * *} \\
(0.0170)\end{array}$ & $\begin{array}{l}0.922^{* \star *} \\
(0.0257)\end{array}$ & $\begin{array}{l}0.908^{\star * *} \\
(0.0170)\end{array}$ & $\begin{array}{l}0.925^{\star * \star} \\
(0.0306)\end{array}$ & $\begin{array}{l}0.857^{* * *} \\
(0.0356)\end{array}$ & $\begin{array}{l}0.958^{\star * *} \\
(0.00955)\end{array}$ & $\begin{array}{l}0.893^{* * *} \\
(0.0164)\end{array}$ & $\begin{array}{l}0.917^{* * *} \\
(0.0151)\end{array}$ \\
\hline Short-term interest rate $(\mathrm{lag}=1 \mathrm{q})$ & $\begin{array}{l}-0.0337^{\star *} \\
(0.0147)\end{array}$ & $\begin{array}{l}-0.0753^{* *} \\
(0.0318)\end{array}$ & $\begin{array}{l}-0.0458^{* *} \\
(0.0232)\end{array}$ & $\begin{array}{c}0.0112 \\
(0.0716)\end{array}$ & $\begin{array}{l}-0.0587^{* \star *} \\
(0.00977)\end{array}$ & $\begin{array}{l}-0.0236 \\
(0.0156)\end{array}$ & $\begin{array}{l}-0.0252^{*} \\
(0.0133)\end{array}$ & $\begin{array}{l}-0.0266^{* * *} \\
(0.00936)\end{array}$ & $\begin{array}{l}-0.00330 \\
(0.0431)\end{array}$ & $\begin{array}{l}-0.0268 \\
(0.0236)\end{array}$ & $\begin{array}{l}-0.0252 \\
(0.0206)\end{array}$ & $\begin{array}{l}-0.0331 \\
(0.0252)\end{array}$ \\
\hline GDP growth (real, lag=1q) & $\begin{array}{l}0.178^{\star * *} \\
(0.0443)\end{array}$ & $\begin{array}{c}0.117^{* *} \\
(0.0539)\end{array}$ & $\begin{array}{l}0.226^{\star * \star} \\
(0.0484)\end{array}$ & $\begin{array}{c}0.190 \\
(0.173)\end{array}$ & $\begin{array}{c}0.0871 \\
(0.0569)\end{array}$ & $\begin{array}{l}0.212^{* * *} \\
(0.0583)\end{array}$ & $\begin{array}{l}0.188^{* * *} \\
(0.0558)\end{array}$ & $\begin{array}{c}0.0852 \\
(0.0587)\end{array}$ & $\begin{array}{l}0.187^{* *} \\
(0.0768)\end{array}$ & $\begin{array}{c}0.0625^{\star * *} \\
(0.0232)\end{array}$ & $\begin{array}{l}0.163^{* \star *} \\
(0.0481)\end{array}$ & $\begin{array}{c}0.0967 \\
(0.0928)\end{array}$ \\
\hline $\begin{array}{l}\text { LTV level (change, lag=1q) } \\
\quad(-/+=\text { tightening/loosening) }\end{array}$ & $\begin{array}{c}0.0418 \\
(0.0616)\end{array}$ & $\begin{array}{c}0.0661 \\
(0.0590)\end{array}$ & $\begin{array}{c}0.0744 \\
(0.0847)\end{array}$ & $\begin{array}{c}0.0464 \\
(0.0293)\end{array}$ & $\begin{array}{l}-0.0488 \\
(0.0694)\end{array}$ & $\begin{array}{c}0.0107 \\
(0.0883)\end{array}$ & $\begin{array}{l}-0.0228 \\
(0.0476)\end{array}$ & $\begin{array}{l}0.0720^{*} \\
(0.0428)\end{array}$ & $\begin{array}{c}0.0668 \\
(0.0582)\end{array}$ & $\begin{array}{c}0.0206 \\
(0.0426)\end{array}$ & $\begin{array}{c}-0.0589 \\
(0.0479)\end{array}$ & $\begin{array}{l}-0.104^{\star *} \\
(0.0495)\end{array}$ \\
\hline LTV level (change, lag=2q) & $\begin{array}{c}0.0321 \\
(0.0412)\end{array}$ & $\begin{array}{c}-0.0199 \\
(0.0517)\end{array}$ & $\begin{array}{l}0.136^{\star \star \star} \\
(0.0384)\end{array}$ & $\begin{array}{l}0.0610^{\star *} \\
(0.0277)\end{array}$ & $\begin{array}{c}0.0406 \\
(0.0597)\end{array}$ & $\begin{array}{l}-0.160 \\
(0.200)\end{array}$ & $\begin{array}{c}0.0380 \\
(0.0541)\end{array}$ & $\begin{array}{l}0.00954 \\
(0.0167)\end{array}$ & $\begin{array}{c}0.0358 \\
(0.0357)\end{array}$ & $\begin{array}{c}0.0473 \\
(0.0338)\end{array}$ & $\begin{array}{c}0.0545 \\
(0.0376)\end{array}$ & $\begin{array}{l}0.114^{\star \star *} \\
(0.0288)\end{array}$ \\
\hline LTV level (change, lag=3q) & $\begin{array}{l}0.0472^{*} \\
(0.0287)\end{array}$ & $\begin{array}{l}0.0422^{* *} \\
(0.0192)\end{array}$ & $\begin{array}{l}0.0931^{* *} \\
(0.0381)\end{array}$ & $\begin{array}{l}0.0737^{* *} \\
(0.0360)\end{array}$ & $\begin{array}{c}0.0450 \\
(0.0519)\end{array}$ & $\begin{array}{l}0.0760 \\
(0.136)\end{array}$ & $\begin{array}{c}0.0524 \\
(0.0345)\end{array}$ & $\begin{array}{c}0.0170 \\
(0.0182)\end{array}$ & $\begin{array}{c}0.0194 \\
(0.0274)\end{array}$ & $\begin{array}{c}0.0599 \\
(0.0689)\end{array}$ & $\begin{array}{l}0.0816^{*} \\
(0.0482)\end{array}$ & $\begin{array}{l}0.119^{\star *} \\
(0.0485)\end{array}$ \\
\hline LTV level (change, lag=4q) & $\begin{array}{l}0.0535^{\star \star} \\
(0.0250)\end{array}$ & $\begin{array}{l}0.00678 \\
(0.0171)\end{array}$ & $\begin{array}{c}0.0727^{\star * *} \\
(0.0243)\end{array}$ & $\begin{array}{c}0.0522 \\
(0.0539)\end{array}$ & $\begin{array}{c}0.0135 \\
(0.0272)\end{array}$ & $\begin{array}{c}0.204 \\
(0.164)\end{array}$ & $\begin{array}{l}0.0750^{* *} \\
(0.0358)\end{array}$ & $\begin{array}{c}0.0233 \\
(0.0275)\end{array}$ & $\begin{array}{l}-0.00458 \\
(0.0241)\end{array}$ & $\begin{array}{c}0.101^{\star \star} \\
(0.0473)\end{array}$ & $\begin{array}{l}0.0561^{\star *} \\
(0.0244)\end{array}$ & $\begin{array}{c}0.0908^{\star \star \star} \\
(0.0292)\end{array}$ \\
\hline Constant & $\begin{array}{c}0.451 \\
(1.127)\end{array}$ & $\begin{array}{l}1.305^{\star \star} \\
(0.616)\end{array}$ & $\begin{array}{c}4.636^{\star \star \star} \\
(1.413)\end{array}$ & $\begin{array}{l}9.914^{\star \star} \\
(4.684)\end{array}$ & $\begin{array}{l}-0.112 \\
(1.041)\end{array}$ & $\begin{array}{c}0.673 \\
(0.641)\end{array}$ & $\begin{array}{c}0.497 \\
(0.909)\end{array}$ & $\begin{array}{c}1.721^{\star \star \star} \\
(0.454)\end{array}$ & $\begin{array}{c}8.420^{\star \star \star} \\
(0.657)\end{array}$ & $\begin{array}{c}-4.791^{\star \star *} \\
(0.207)\end{array}$ & $\begin{array}{c}0.682 \\
(1.207)\end{array}$ & $\begin{array}{c}27.24^{\star \star \star} \\
(1.744)\end{array}$ \\
\hline Obser & 3,236 & 2,018 & 1,262 & 674 & 1,883 & 479 & 1,799 & 1,790 & 1,302 & 435 & 1,513 & 526 \\
\hline Number of countries & 58 & 34 & 24 & 13 & 32 & 8 & 31 & 31 & 22 & 7 & 57 & 24 \\
\hline Sum coeff LTV level & 0.17 & 0.10 & 0.38 & 0.23 & 0.05 & 0.13 & 0.14 & 0.12 & 0.12 & 0.23 & 0.13 & 0.22 \\
\hline F-test $p$-value & 0.15 & 0.28 & $0.01^{* * *}$ & $0.07^{*}$ & 0.72 & 0.80 & 0.25 & $0.05^{\star \star}$ & 0.34 & 0.11 & 0.16 & $0.02^{* *}$ \\
\hline $\mathrm{AR}(1)$ Test & 0.002 & 0.064 & 0.001 & 0.044 & 0.034 & 0.064 & 0.020 & 0.113 & 0.125 & 0.024 & 0.005 & 0.003 \\
\hline $\mathrm{AR}(2)$ Test & 0.557 & 0.838 & 0.729 & 0.154 & 0.0915 & 0.812 & 0.386 & 0.117 & 0.294 & 0.205 & 0.672 & 0.482 \\
\hline
\end{tabular}

Sources: The iMaPP database, Bloomberg, BIS, OECD, others (see Appendix IV), and the authors' estimation.

Notes: The table reports the effects of a one-ppt LTV tightening when additionally controlling for other macroprudential policy actions, obtained by the Arellano-Bover-Blundell-Bond system GMM estimation with the timing assumption. The row labeled as "Sum coeff LTV level" shows the cumulative effects after four quarters. All specifications include country and time fixed

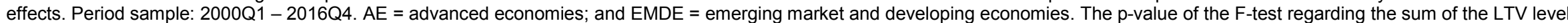

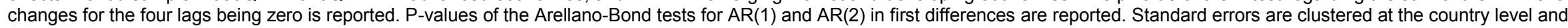
reported in parentheses. Confidence levels: ${ }^{* *} p<0.01,{ }^{* *} p<0.05,{ }^{*} p<0.1$. 


\section{Appendix VIII Table 14. Robustness (System GMM): The Effects of $\Delta$ LTV Limits on Real Private Consumption growth}

\begin{tabular}{|c|c|c|c|c|c|c|c|c|c|c|c|c|}
\hline \multirow[b]{3}{*}{ Group } & \multirow[t]{2}{*}{ (1) } & \multirow[t]{2}{*}{ (2) } & \multirow[t]{2}{*}{ (3) } & $(4)$ & (5) & (6) & $\begin{array}{c}(7) \\
\text { (n) }\end{array}$ & (8) & \multirow{2}{*}{$\begin{array}{r}(9) \\
\text { real) }\end{array}$} & \multirow[t]{2}{*}{$(10)$} & \multirow[t]{2}{*}{ (11) } & \multirow[t]{2}{*}{$(12)$} \\
\hline & & & & Dep & endent Varia & ble: Private $\mathrm{co}$ & onsumption & (\% change, $y$ & & & & \\
\hline & ALL & $\mathrm{AE}$ & EMDE & ASIA & EUROPE & AMERICAS & $\begin{array}{c}\text { Hi FX } \\
\text { Regime } \\
\text { Flexibility } \\
\end{array}$ & $\begin{array}{l}\text { Hi Capital } \\
\text { Openness }\end{array}$ & $\begin{array}{c}\text { Hi Financial } \\
\text { Development }\end{array}$ & $\begin{array}{l}\text { Hi DTI Low- } \\
\text { Income } \\
\text { Borrowers }\end{array}$ & $\begin{array}{l}\text { Positive } \\
\text { Credit Gap }\end{array}$ & $\begin{array}{c}\text { Positive } \\
\text { Credit Gap \& } \\
\text { EMDE only }\end{array}$ \\
\hline Private consumption ( $\%$ change, yoy, real, lag=1q) & $\begin{array}{l}0.861^{* * *} \\
(0.0178)\end{array}$ & $\begin{array}{l}0.856^{* * *} \\
(0.0168)\end{array}$ & $\begin{array}{l}0.876^{* * *} \\
(0.0189)\end{array}$ & $\begin{array}{l}0.747^{\star * *} \\
(0.0473)\end{array}$ & $\begin{array}{l}0.856^{* * *} \\
(0.0213)\end{array}$ & $\begin{array}{l}0.934^{* * *} \\
(0.0172)\end{array}$ & $\begin{array}{l}0.884^{* * *} \\
(0.0172)\end{array}$ & $\begin{array}{l}0.855^{\star * *} \\
(0.0235)\end{array}$ & $\begin{array}{l}0.815^{* \star *} \\
(0.0316)\end{array}$ & $\begin{array}{l}0.853^{* * *} \\
(0.0192)\end{array}$ & $\begin{array}{l}0.910^{* * *} \\
(0.0169)\end{array}$ & $\begin{array}{l}0.908^{* * *} \\
(0.0220)\end{array}$ \\
\hline Short-term interest rate $(\operatorname{lag}=1 \mathrm{q})$ & $\begin{array}{l}-0.0374^{* *} \\
(0.0156)\end{array}$ & $\begin{array}{c}-0.0480^{* * *} \\
(0.0154)\end{array}$ & $\begin{array}{c}-0.0330^{* *} \\
(0.0150)\end{array}$ & $\begin{array}{l}-0.0747^{*} \\
(0.0392)\end{array}$ & $\begin{array}{c}-0.0424^{* * *} \\
(0.0104)\end{array}$ & $\begin{array}{c}-0.0165^{*} \\
(0.00858)\end{array}$ & $\begin{array}{c}-0.0259^{* *} \\
(0.0118)\end{array}$ & $\begin{array}{c}-0.0400^{* *} \\
(0.0158)\end{array}$ & $\begin{array}{c}0.0117 \\
(0.0191)\end{array}$ & $\begin{array}{l}-0.0416 \\
(0.0259)\end{array}$ & $\begin{array}{c}-0.0204^{* *} \\
(0.0101)\end{array}$ & $\begin{array}{c}-0.0311^{* *} \\
(0.0144)\end{array}$ \\
\hline GDP growth $($ real, lag=1q) & $\begin{array}{r}-0.00542 \\
(0.0241)\end{array}$ & $\begin{array}{l}-0.0311 \\
(0.0260)\end{array}$ & $\begin{array}{l}-0.0398 \\
(0.0355)\end{array}$ & $\begin{array}{l}0.00801 \\
(0.0433)\end{array}$ & $\begin{array}{l}-0.0175 \\
(0.0230)\end{array}$ & $\begin{array}{l}-0.117^{\star *} \\
(0.0529)\end{array}$ & $\begin{array}{c}-0.0819^{* * *} \\
(0.0294)\end{array}$ & $\begin{array}{l}0.00508 \\
(0.0276)\end{array}$ & $\begin{array}{l}0.00608 \\
(0.0196)\end{array}$ & $\begin{array}{c}0.0234 \\
(0.0186)\end{array}$ & $\begin{array}{l}-0.0458 \\
(0.0292)\end{array}$ & $\begin{array}{l}-0.0435 \\
(0.0490)\end{array}$ \\
\hline $\begin{array}{l}\text { LTV level (change, lag=1q) } \\
\qquad(-/+=\text { tightening/loosening) }\end{array}$ & $\begin{array}{l}0.00349 \\
(0.0329)\end{array}$ & $\begin{array}{l}-0.00477 \\
(0.0444)\end{array}$ & $\begin{array}{c}0.0372 \\
(0.0323)\end{array}$ & $\begin{array}{l}0.00952 \\
(0.0278)\end{array}$ & $\begin{array}{l}-0.0127 \\
(0.0379)\end{array}$ & $\begin{array}{l}-0.0477 \\
(0.0937)\end{array}$ & $\begin{array}{l}-0.0341 \\
(0.0366)\end{array}$ & $\begin{array}{l}0.0248 \\
(0.0265)\end{array}$ & $\begin{array}{c}0.0151 \\
(0.0275)\end{array}$ & $\begin{array}{c}0.0603 \\
(0.0782)\end{array}$ & $\begin{array}{l}-0.0305 \\
(0.0411)\end{array}$ & $\begin{array}{c}0.0103 \\
(0.0349)\end{array}$ \\
\hline LTV level (change, lag=2q) & $\begin{array}{c}0.0170 \\
(0.0188)\end{array}$ & $\begin{array}{l}0.00477 \\
(0.0142)\end{array}$ & $\begin{array}{c}0.0207 \\
(0.0306)\end{array}$ & $\begin{array}{l}-0.0188 \\
(0.0143)\end{array}$ & $\begin{array}{l}0.00640 \\
(0.0307)\end{array}$ & $\begin{array}{l}-0.0330 \\
(0.0791)\end{array}$ & $\begin{array}{c}0.0128 \\
(0.0183)\end{array}$ & $\begin{array}{c}0.0347 \\
(0.0316)\end{array}$ & $\begin{array}{l}-0.0232 \\
(0.0153)\end{array}$ & $\begin{array}{c}0.0290 \\
(0.0524)\end{array}$ & $\begin{array}{c}0.0450 \\
(0.0306)\end{array}$ & $\begin{array}{l}0.0774^{* *} \\
(0.0383)\end{array}$ \\
\hline LTV level (change, lag $=3 q$ ) & $\begin{array}{l}0.00651 \\
(0.0139)\end{array}$ & $\begin{array}{c}0.0128 \\
(0.0154)\end{array}$ & $\begin{array}{r}-0.00402 \\
(0.0212)\end{array}$ & $\begin{array}{l}0.00715 \\
(0.0181)\end{array}$ & $\begin{array}{c}0.0153 \\
(0.0211)\end{array}$ & $\begin{array}{c}0.111 \\
(0.104)\end{array}$ & $\begin{array}{l}0.0250^{*} \\
(0.0131)\end{array}$ & $\begin{array}{l}0.00249 \\
(0.0186)\end{array}$ & $\begin{array}{c}0.0152 \\
(0.0159)\end{array}$ & $\begin{array}{l}-0.00956 \\
(0.0322)\end{array}$ & $\begin{array}{r}-0.00709 \\
(0.0201)\end{array}$ & $\begin{array}{c}0.000847 \\
(0.0242)\end{array}$ \\
\hline LTV level (change, lag=4q) & $\begin{array}{c}0.0348 \\
(0.0231)\end{array}$ & $\begin{array}{l}-0.0118 \\
(0.0158)\end{array}$ & $\begin{array}{l}0.0689^{* *} \\
(0.0329)\end{array}$ & $\begin{array}{l}0.0388^{* *} \\
(0.0197)\end{array}$ & $\begin{array}{c}0.0347 \\
(0.0337)\end{array}$ & $\begin{array}{c}-0.0873^{* * *} \\
(0.00943)\end{array}$ & $\begin{array}{c}0.0152 \\
(0.0232)\end{array}$ & $\begin{array}{c}0.0269 \\
(0.0365)\end{array}$ & $\begin{array}{l}-0.0147 \\
(0.0238)\end{array}$ & $\begin{array}{l}0.260^{*} \\
(0.155)\end{array}$ & $\begin{array}{c}0.0301 \\
(0.0337)\end{array}$ & $\begin{array}{l}0.0655^{\star *} \\
(0.0328)\end{array}$ \\
\hline Constant & $\begin{array}{c}-0.0734 \\
(0.620)\end{array}$ & $\begin{array}{l}1.853^{* * *} \\
(0.539)\end{array}$ & $\begin{array}{c}2.196^{\star \star *} \\
(0.423)\end{array}$ & $\begin{array}{l}-2.939 \\
(2.058)\end{array}$ & $\begin{array}{c}0.899 \\
(0.560)\end{array}$ & $\begin{array}{c}0.225 \\
(0.350)\end{array}$ & $\begin{array}{l}0.0116 \\
(0.874)\end{array}$ & $\begin{array}{c}0.870^{* \star *} \\
(0.264)\end{array}$ & $\begin{array}{c}-1.313^{* *} \\
(0.561)\end{array}$ & $\begin{array}{l}0.0649 \\
(0.387)\end{array}$ & $\begin{array}{c}0.294 \\
(0.318)\end{array}$ & $\begin{array}{c}-0.644^{* * *} \\
(0.235)\end{array}$ \\
\hline Observations & 3,187 & 1,953 & 1,360 & 693 & 1,817 & 468 & 1,854 & 1,764 & 1,197 & 441 & 1,400 & 545 \\
\hline Number of countries & 54 & 31 & 23 & 11 & 29 & 8 & 30 & 29 & 19 & 7 & 51 & 23 \\
\hline Sum coeff LTV level & 0.06 & 0.00 & 0.12 & 0.04 & 0.04 & -0.06 & 0.02 & 0.09 & -0.01 & 0.34 & 0.04 & 0.15 \\
\hline F-test p-value & 0.25 & 0.99 & $0.05^{*}$ & 0.56 & 0.53 & 0.76 & 0.76 & 0.21 & 0.90 & $0.07^{*}$ & 0.63 & $0.04^{* *}$ \\
\hline$A R(1)$ Test & $4.68 \mathrm{e}-07$ & $7.61 \mathrm{e}-05$ & 0.000125 & 0.00598 & 0.000161 & 0.0683 & $4.19 \mathrm{e}-05$ & 0.000255 & 0.000389 & 0.108 & $4.82 \mathrm{e}-07$ & 0.000172 \\
\hline AR(2) Test & 0.488 & 0.953 & 0.424 & 0.218 & 0.532 & 0.194 & 0.169 & 0.0979 & 0.356 & 0.608 & 0.548 & 0.252 \\
\hline
\end{tabular}

Sources: The iMaPP database, Bloomberg, BIS, OECD, others (see Appendix IV), and the authors' estimation.

Notes: The table reports the effects of a one-ppt LTV tightening when additionally controlling for other macroprudential policy actions, obtained by the Arellano-Bover-Blundell-Bond system GMM estimation with the timing assumption. The row labeled as "Sum coeff LTV level" shows the cumulative effects after four quarters. All specifications include country and time fixed effects. Period sample: 2000Q1-2016Q4. AE = advanced economies; and EMDE = emerging market and developing economies. The p-value of the F-test regarding the sum of the LTV level changes for the four lags being zero is reported. P-values of the Arellano-Bond tests for $A R(1)$ and $A R(2)$ in first differences are reported. Standard errors clustered at the country level are reported in parentheses. Confidence levels: ${ }^{* * *} p<0.01,{ }^{* *} p<0.05,{ }^{*} p<0.1$. 
Appendix VIII Table 15. Interactions: The Effects of $\Delta$ LTV Limits, Conditional on LTV Level

\begin{tabular}{|c|c|c|c|c|c|c|}
\hline \multirow{3}{*}{$\begin{array}{l}\text { Dependent Variable: } \\
\text { Group: }\end{array}$} & (1) & $(2)$ & (3) & (4) & (5) & (6) \\
\hline & \multicolumn{3}{|c|}{$\begin{array}{l}\text { Household Credit } \\
(\% \text { change, yoy, real })\end{array}$} & \multicolumn{3}{|c|}{$\begin{array}{l}\text { Private Consumption } \\
\text { (\% change, yoy, real) }\end{array}$} \\
\hline & ALL & $\mathrm{AE}$ & EMDE & ALL & $\mathrm{AE}$ & EMDE \\
\hline Household credit ( $\%$ change, yoy, real, lag=1q) & $\begin{array}{l}0.889^{* * *} \\
(0.0181)\end{array}$ & $\begin{array}{l}0.884^{* * *} \\
(0.0440)\end{array}$ & $\begin{array}{l}0.890^{* * *} \\
(0.0142)\end{array}$ & & & \\
\hline Private consumption ( $\%$ change, yoy, real, lag=1q) & & & & $\begin{array}{l}0.830^{\star * *} \\
(0.0217)\end{array}$ & $\begin{array}{l}0.842^{* * *} \\
(0.0238)\end{array}$ & $\begin{array}{l}0.805^{\star * *} \\
(0.0319)\end{array}$ \\
\hline Short-term interest rate $(\mathrm{lag}=1 \mathrm{q})$ & $\begin{array}{c}-0.0927^{* * *} \\
(0.0215)\end{array}$ & $\begin{array}{c}-0.102 \\
(0.0782)\end{array}$ & $\begin{array}{l}-0.106^{* * *} \\
(0.0301)\end{array}$ & $\begin{array}{c}-0.0852^{* * *} \\
(0.0242)\end{array}$ & $\begin{array}{l}-0.0818^{* *} \\
(0.0364)\end{array}$ & $\begin{array}{c}-0.0955^{* * *} \\
(0.0297)\end{array}$ \\
\hline GDP growth (real, lag=1q) & $\begin{array}{l}0.153^{\star * *} \\
(0.0536)\end{array}$ & $\begin{array}{c}0.146^{* *} \\
(0.0678)\end{array}$ & $\begin{array}{c}0.160 \\
(0.0937)\end{array}$ & $\begin{array}{l}-0.0365 \\
(0.0279)\end{array}$ & $\begin{array}{l}-0.0633 \\
(0.0416)\end{array}$ & $\begin{array}{l}-0.00201 \\
(0.0489)\end{array}$ \\
\hline LTV level (high, dummy) & $\begin{array}{c}0.306 \\
(0.375)\end{array}$ & $\begin{array}{c}0.256 \\
(0.444)\end{array}$ & $\begin{array}{c}0.250 \\
(0.573)\end{array}$ & $\begin{array}{l}-0.0728 \\
(0.171)\end{array}$ & $\begin{array}{c}0.125 \\
(0.201)\end{array}$ & $\begin{array}{l}-0.460 \\
(0.341)\end{array}$ \\
\hline$\Delta$ LTV level $($ lag = 1q) & $\begin{array}{c}0.0204 \\
(0.0424)\end{array}$ & $\begin{array}{c}0.0295 \\
(0.0313)\end{array}$ & $\begin{array}{l}0.0120 \\
(0.0679)\end{array}$ & $\begin{array}{l}0.000974 \\
(0.0177)\end{array}$ & $\begin{array}{c}0.0142 \\
(0.0250)\end{array}$ & $\begin{array}{l}-0.00167 \\
(0.0283)\end{array}$ \\
\hline LTV level (high) * $\Delta$ LTV level $($ lag $=1 q)$ & $\begin{array}{l}-0.0563 \\
(0.0825)\end{array}$ & $\begin{array}{c}0.0435 \\
(0.0469)\end{array}$ & $\begin{array}{c}-0.00549 \\
(0.138)\end{array}$ & $\begin{array}{r}-0.00914 \\
(0.0375)\end{array}$ & $\begin{array}{l}-0.0199 \\
(0.0401)\end{array}$ & $\begin{array}{c}0.0265 \\
(0.0519)\end{array}$ \\
\hline$\Delta$ LTV level $($ lag $=2 q)$ & $\begin{array}{c}0.0319 \\
(0.0403)\end{array}$ & $\begin{array}{l}-0.0232 \\
(0.0664)\end{array}$ & $\begin{array}{l}0.0794 \\
(0.0509)\end{array}$ & $\begin{array}{c}0.0220 \\
(0.0207)\end{array}$ & $\begin{array}{l}0.00622 \\
(0.0164)\end{array}$ & $\begin{array}{c}0.0319 \\
(0.0368)\end{array}$ \\
\hline LTV level (high) ${ }^{*} \Delta$ LTV level $($ lag $=2 q)$ & $\begin{array}{l}0.0200 \\
(0.118)\end{array}$ & $\begin{array}{c}0.0580 \\
(0.0932)\end{array}$ & $\begin{array}{l}-0.0127 \\
(0.0907)\end{array}$ & $\begin{array}{c}0.0201 \\
(0.0409)\end{array}$ & $\begin{array}{l}-0.0153 \\
(0.0410)\end{array}$ & $\begin{array}{c}0.0226 \\
(0.0685)\end{array}$ \\
\hline$\Delta$ LTV level $($ lag $=3 q)$ & $\begin{array}{l}0.0432^{*} \\
(0.0245)\end{array}$ & $\begin{array}{c}0.0356 \\
(0.0349)\end{array}$ & $\begin{array}{c}0.0495 \\
(0.0370)\end{array}$ & $\begin{array}{c}0.0145 \\
(0.0155)\end{array}$ & $\begin{array}{c}0.0168 \\
(0.0174)\end{array}$ & $\begin{array}{l}0.00904 \\
(0.0282)\end{array}$ \\
\hline LTV level (high) * $\Delta$ LTV level $($ lag $=3 q)$ & $\begin{array}{l}0.0410 \\
(0.246)\end{array}$ & $\begin{array}{l}-0.00131 \\
(0.0545)\end{array}$ & $\begin{array}{l}0.0246 \\
(0.221)\end{array}$ & $\begin{array}{c}-0.00641 \\
(0.101)\end{array}$ & $\begin{array}{l}-0.0479 \\
(0.0342)\end{array}$ & $\begin{array}{l}-0.0342 \\
(0.110)\end{array}$ \\
\hline$\Delta$ LTV level $($ lag $=4 q)$ & $\begin{array}{c}0.0262 \\
(0.0255)\end{array}$ & $\begin{array}{l}0.00882 \\
(0.0242)\end{array}$ & $\begin{array}{c}0.0562 \\
(0.0422)\end{array}$ & $\begin{array}{l}0.0458^{*} \\
(0.0251)\end{array}$ & $\begin{array}{l}-0.00853 \\
(0.0182)\end{array}$ & $\begin{array}{l}0.0958^{\star *} \\
(0.0388)\end{array}$ \\
\hline LTV level (high) * $\Delta$ LTV level $($ lag $=4 q)$ & $\begin{array}{c}0.0427 \\
(0.0745)\end{array}$ & $\begin{array}{c}0.0421 \\
(0.0308)\end{array}$ & $\begin{array}{c}0.0145 \\
(0.0979)\end{array}$ & $\begin{array}{l}-0.0441 \\
(0.0352)\end{array}$ & $\begin{array}{c}0.0523 \\
(0.0725)\end{array}$ & $\begin{array}{l}-0.114^{\star *} \\
(0.0492)\end{array}$ \\
\hline Sum coefficients (LTV level low) & 0.120 & 0.053 & 0.196 & 0.082 & 0.036 & 0.133 \\
\hline Sum coefficients (LTV level high) & 0.173 & 0.196 & 0.224 & 0.062 & 0.028 & 0.041 \\
\hline Observations & 3,236 & 2,018 & 1,218 & 3,187 & 1,953 & 1,234 \\
\hline R-squared & 0.918 & 0.912 & 0.925 & 0.824 & 0.815 & 0.836 \\
\hline
\end{tabular}

Sources: The iMaPP database, Bloomberg, BIS, OECD, others (see Appendix IV), and the authors' estimation.

Notes: The table reports the effects of a one-ppt LTV tightening after four quarters with interaction terms with the dummies for high and low initial LTV levels, obtained by the fixed effects estimation with the timing assumption. The rows labeled as "Sum coefficients" show the cumulative effects after four quarters for each group. All specifications include country and time fixed effects. Period sample: 2000Q1 - 2016Q4. AE = advanced economies; and EMDE = emerging market and developing economies. Standard errors clustered at the country level are reported in parentheses. Confidence levels: ${ }^{* * *} p<0.01,{ }^{* *} p<0.05$, ${ }^{*} p<0.1$. 


\section{References}

Akinci, Ozge, and Jane Olmstead-Rumsey, 2018, "How Effective are Macroprudential Policies? An Empirical Investigation,” Journal of Financial Intermediation, Vol. 33, pp. 33-57.

Alter, Adrian, Alan Xiaochen Feng, and Nico Valckx. 2018, "Understanding the Macro-Financial Effects of Household Debt: A Global Perspective," IMF Working Paper, WP/18/76 (Washington: International Monetary Fund).

Alpanda, Sami, and Sarah Zubairy, 2017, “Addressing Household Indebtedness: Monetary, Fiscal or Macrorprudential Policy?” European Economic Review Vol. 92: pp. 47-73.

Angrist, Joshua D., Òscar Jordà, and Guido M. Kuersteiner, 2016, "Semiparametric Estimates of Monetary Policy Effects: String Theory Revisited." Journal of Business and Economic Statistics, Vol. 36, pp. 371-387.

Arellano, Manuel, and Olympia Bover, 1995, “Another Look at the Instrumental Variable Estimation of Error-Components Models," Journal of Econometrics Vol. 68 (1): 29-51.

Arregui, Nicolas, Jaromír Beneš, Ivo Krznar, and Srobona Mitra, S., 2013, "Evaluating the Net Benefits of Macroprudential Policy: A Cookbook.” IMF Working Paper, WP/13/167 (Washington: International Monetary Fund).

Basten, Christoph, and Catherine Koch, 2015, "Higher Bank Capital Requirements and Mortgage Pricing: Evidence from the Countercyclical Capital Buffer (CCB)," BIS Working Paper No. 511.

Blundell, Richard, and Stephen Bond, 1998, "Initial Conditions and Moment Restrictions in Dynamic Panel Data Models,” Journal of Econometrics, Vol. 87, pp. 115-43.

Brandao, Luis, Gaston Gelos, Machiko Narita, and Erlend Nier, (forthcoming), "Toward a CostBenefit Analysis of Macroprudential and Monetary Policies."

Bruno, Valentina, Ilhyock Shim, Hyun Song Shin, 2016, "Comparative Assessment of Macroprudential Policies,” Journal of Financial Stability, Vol. 28, pp. 183-202.

Budnik, Katarzyna, and Johannes Kleibl, 2018, "Macroprudential Regulation in the European Union in 1995-2014: Introducing a New Data Set on Policy Actions of a Macroprudential Nature," ECB Working Paper No. 2123.

Cerutti, Eugenio, Stijn Claessens, and Luc Laeven, 2017a, "The Use and Effectiveness of Macroprudential Policies: New Evidence,” Journal of Financial Stability, Vol. 28, pp. 203-224.

Cerrutti, Eugenio, Ricardo Correa, Elisabetta Fiorentino, and Esther Segalla, 2017b, "Changes in Prudential Policy Instruments-A New Cross-Country Database," International Journal of Central Banking.

Chinn, Menzie D. and Hiro Ito (2008), "A New Measure of Financial Openness," Journal of Comparative Policy Analysis, Vol. 10 (3): 309-22 (September). 
Crowe, Christopher, Giovanni Dell'Ariccia, Deniz Igan, and Pau Rabanal, 2013, "How to Deal with Real Estate Booms: Lessons from Country Experiences," Journal of Financial Stability, Vol. 9(3), pp. 300-319.

Darbar, Salim M., and Xiaoyong Wu, 2016, "Experiences with Macroprudential Policy-Five Case Studies," Journal of International Commerce, Economics and Policy, Vol. 07, No. 03, 1650014.

Dickerson, Andy, Arne Risa Hole, and Luke Munford, 2011, “A Review of Estimators for the Fixed-Effects Ordered Logit Model," Slides for United Kingdom Stata Users' Group Meetings, Stata Users Group. Available at: http://repec.org/usug2011/UK11_Hole.pdf.

Dimova, Dilyana, Piyabha Kongsamut, and Jerome Vandenbussche, 2016, "Macroprudential Policies in Southeastern Europe," IMF Working Paper, WP/16/29 13 (Washington: International Monetary Fund).

Elliott, Douglas J., Greg Feldberg, and Andreas Lehnert, 2013, “The History of Cyclical Macroprudential Policy in the United States," Federal Reserve Board Finance and Economics Discussion Series 2013-29.

Epure, Mircea, Irina Mihai, Camelia Minoiu, and Jose-Luis Peydro, 2018, "Household Credit, Global Financial Cycle, and Macroprudential Policies: Credit Register Evidence from an Emerging Country," IMF Working Paper, WP/18/13 (Washington: International Monetary Fund).

Galati, Gabriele, and Richhild Moessner, 2018, "What Do We Know About the Effects of Macroprudential Policy?” Economica, Vol. 85: pp. 735-70.

Igan, Deniz, and Heedon Kang, 2011, "Do Loan-to-Value and Debt-to-Income Limits Work? Evidence from Korea," IMF Working Paper, WP/11/297 (Washington: International Monetary Fund).

Ilzetzki, Ethan, Carmen M. Reinhart, and Kenneth S. Rogoff, 2017, "Exchange Arrangements Entering the 21st Century: Which Anchor Will Hold?" NBER Working Paper No. 23134, National Bureau of Economic Research, Cambridge, MA.

International Monetary Fund, 2012a, "The Interaction of Monetary and Macroprudential Policies," IMF Policy Paper, International Monetary Fund, Washington.

,2012b, "The Interaction of Monetary and Macroprudential Policies-Background Paper,” IMF Policy Paper, (Washington: International Monetary Fund). , 2013a, “Key Aspects of Macroprudential Policy,” IMF Policy Paper (Washington: International Monetary Fund).

, 2013b, "Key Aspects of Macroprudential Policy_Background Paper,” IMF Policy Paper (Washington: International Monetary Fund). 
,2014a, "Staff Guidance Note on Macroprudential Policy," IMF Policy Paper (Washington: International Monetary Fund).

,2014b, "Staff Guidance Note on Macroprudential Policy_-Detailed Guidance on

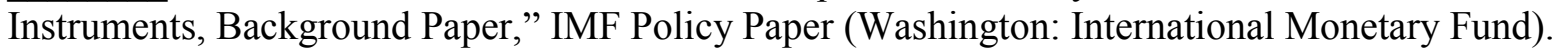

,2017, "Household Debt and Financial Stability," Chapter 2 in Global Financial Stability Report, October, (Washington: International Monetary Fund).

, 2018a, “The IMF’s Annual Macroprudential Policy Survey_Objectives, Design and Policy Responses," IMF Policy Paper and Note to G20, April, (Washington: International Monetary Fund).

,2018b, Statistical Appendix of the April 2018 World Economic Outlook, (Washington: International Monetary Fund).

,2018c, "Macroprudential Policies and House Prices in Europe: An Overview of Recent Experiences," Chapter 2 of November 2018 Regional Economic Outlook, (Washington: International Monetary Fund).

International Monetary Fund, Financial Stability Board, and Bank for International Settlements, 2016, "Elements of Effective Macroprudential Policies." Available at: https://www.imf.org/external/np/g20/pdf/2016/083116.pdf

Jácome, Luis I., and Srobona Mitra, 2015, “LTV and DTI Limits - Going Granular,” IMF Working Paper, WP/15/154 (Washington: International Monetary Fund).

Jordà, Òscar, and Alan M. Taylor, 2016, "The Time for Austerity: Estimating the Average Treatment Effect of Fiscal Policy,” The Economic Journal, 126(590), pp. 219-255.

Lim, Cheng H., Francesco Columba, Alejo Costa, Piyabha Kongsamut, Akira Otani, Mustafa Saiyid, Torsten Wezel, Xiaoyong Wu, 2011, "Macroprudential Policy: What Instruments and How Are They Used? Lessons from Country Experiences," IMF Working Paper 11/238 (Washington: International Monetary Fund).

Lim, Cheng Hoon, Ivo Krznar, Fabian Lipinsky, Akira Otani, and Xiaoyong Wu, 2013, "The Macroprudential Framework: Policy Responsiveness and Institutional Arrangements," IMF Working Paper, WP/13/166 (Washington: International Monetary Fund).

Lunceford, Jared K., and Marie Davidian, 2004, "Stratification and Weighting via the Propensity Score in Estimation of Causal Treatment Effects: A Comparative Study," Statistics in Medicine, Vol. 23: 2937-2960.

Koenker, Roger, and Kevin F. Hallock, 2001, "Quantile Regression, “Journal of Economic Perspectives, Vol. 15, 143-15, http://dx.doi.org/10.1257/jep.15.4.143 
Krznar, Ivo, and James Morsink, 2014, "With Great Power Comes Great Responsibility: Macroprudential Tools at Work in Canada," IMF Working Paper, WP/14/83 (Washington: International Monetary Fund).

Kuttner, Kenneth N., and Ilhyock Shim, 2016, "Can Non-Interest Rate Policies Stabilize Housing Markets? Evidence from a Panel of 57 Economies," Journal of Financial Stability, 26, pp.31-44.

Nickell, Stephen, 1981, "Biases in Dynamic Models with Fixed Effects," Econometrica, 49, 1417-1426.

Poghosyan, Tigran, 2019, "How Effective is Macroprudential Policy? Evidence from Lending Restriction Measures in EU Countries," IMF Working Paper, forthcoming (Washington: International Monetary Fund).

Powell, David. 2015, “Quantile Regression with Nonadditive Fixed Effects,” RAND Labor and Population Working Paper. ,2016, "Quantile Treatment Effects in the Presence of Covariates," RAND Labor and Population Working Paper.

Richter, Bjorn, Moritz Schularick, and Ilhyock Shim, 2018, "The Costs of Macroprudential Policy," NBER Working Paper 24989.

Robins, M. James, Andrea Rotnitzky, and Lue Ping Zhao, 1994, "Estimation of Regression Coefficients When Some Regressors are not Always Observed," Journal of the American Statistical Association, Vol. 89(427), pp. 846-66.

Roodman, David, 2009, "How to Do Xtabond2: An Introduction to Difference and System GMM in Stata." Stata Journal, Vol. 9, pp. 86-136.

Shim, Ilhyock, Bilyana Bogdanova, Jimmy Shek, and Agne Subelyte, 2013, "Database for Policy Actions on Housing Markets," BIS Quarterly Review, September 2013.

Svensson, Lars, 2017, “Cost-Benefit Analysis of Leaning Against the Wind," Journal of Monetary Economics, Vol. 90, pp. 193-213.

Svirydzenka, Katsiaryna, 2016, "Introducing a New Broad-Based Index of Financial Development," IMF Working Paper, WP/16/5 (Washington: International Monetary Fund).

Vandenbussche, Jerome, Ursula Vogel, and Enrica Detragiache, E., 2015, "Macroprudential Policies and Housing Prices: A New Database and Empirical Evidence for Central, Eastern, and Southeastern Europe," Journal of Money, Credit and Banking, Supplement to Vol. 47, No. 1, pp. 343-377.

Wooldridge, Jeffrey M., 2010, "Econometric Analysis of Cross Section and Panel Data. 2nd ed." (Massachusetts: MIT Press).

Zhang, Longmei, and Edda Zoli, 2016, "Leaning Against the Wind: Macroprudential Policy in Asia." Journal of Asian Economics, Vol. 42, pp. 33-52. 